\title{
The Truman Administration and Non-use of the Atomic Bomb During the Korean War, June 1950 to January 1953
}

Malcolm MacMillan Craig

A thesis submitted in fulfilment of the requirements for the degree of Master of Arts at Victoria University of Wellington 
Table of Contents

Abstract $\quad$ iii

Acknowledgements iv

Acronyms and Usage $\quad \mathrm{V}$

List of Key Figures vii

Map of Korea $\quad$ x

Introduction $\quad 1$

$1 \quad$ 'A Peculiar Monster' 21

June to November 1950

$2 \quad$ 'Always Under Consideration' 46

Early December 1950

3 'Top Secret Malarky'

67

Mid December 1950 to March 1951

$4 \quad$ 'Prepare For Armageddon'

April to June 1951

5 'Unthinkable For Rational Men'

July 1951 to January 1953

Conclusion 


\begin{abstract}
This thesis examines the Truman administration's non-use of nuclear weapons during the Korean War, June 1950 to January 1953. It investigates the entirety of the Truman administration's experience of the Korean War, rather than focusing on certain key periods. By examining official documentation, memoirs, newspaper reports, and information about public opinion, this thesis explains why the Truman administration chose not to utilise the atomic arsenal. It examines the opinions and influence of significant decision makers such as President Harry S. Truman, Secretary of State Dean Acheson, and Director of the Policy Planning Staff Paul H. Nitze. Truman, as president and ultimate decision maker, will be paid special attention, not least on account of his unique experience of having ordered the atomic attacks on Japan in 1945. This thesis also looks into the position of high-ranking military officers, such as General Omar N. Bradley, General Hoyt S. Vandenberg, and General Matthew B. Ridgway. In order to explain non-use, this thesis also investigates the influence of foreign allies and foreign opinion, particularly that expressed by the United Kingdom, the United States' most important ally. The role of public opinion within the United States is also considered. By examining in detail all of these factors and building a composite picture of the forces acting upon the administration, this thesis provides a more rounded and nuanced view of non-use by the Truman administration during the Korean War than that offered by the existing scholarship. It demonstrates that non-use was always a complex and problematic matter.
\end{abstract}




\section{Acknowledgements}

Thanks must go first to my supervisors Dolores Janiewski and Malcolm McKinnon for their invaluable advice and guidance without which this thesis would not have been completed. Thanks also to my fellow postgraduate students James Campbell, Michael Devine, Michael Gill, Nick Radburn, and Sam Ritchie for their friendship and help. I am also grateful to all the archivists who aided me in finding primary materials, in particular Felicity Rashbrooke of the New Zealand Parliamentary Library, Wellington; Randy Sowell of the Harry S. Truman Presidential Library, Independence, Missouri; and the staff of the U.S. National Archives and Records Administration, College Park, Maryland. I would also like to thank all the members of staff of the Victoria University of Wellington History department, in particular Steve Behrendt, Pauline Keating, Alexander Maxwell, and Evan Roberts. Finally, special thanks go to my family, friends, and partner Jaqui for their encouragement and support throughout my MA. 


\section{Acronyms and Usage}

\section{Acronyms Used in This Thesis}

AEC: Atomic Energy Commission

CIA: Central Intelligence Agency

CIA-FOIA: CIA Freedom of Information Act Electronic Reading Room

CPVA: Communist People's Volunteer Army

CRH: U.S. Congressional Record-House

CRS: U.S. Congressional Record-Senate

DNSA: Digital National Security Archive

DPRK: Democratic People's Republic of Korea ('North Korea')

FRUS: Foreign Relations of the United States

GOP: The 'Grand Old Party' (traditional nickname of the Republican Party of the United States)

HSTL: Harry S. Truman Presidential Library, Independence, Missouri

JCAE: Joint Congressional Committee on Atomic Energy

JCS: Joints Chiefs of Staff

JSRB: Joint Strategic Resources Board

NARA: U.S. National Archives and Records Administration, College Park, Maryland

NATO: North Atlantic Treaty Organisation

NIE: National Intelligence Estimate

NSC: National Security Council

NSRB: National Security Resources Board

OIR: Office of Intelligence Research (U.S. Department of State)

ORO: Operations Research Office (Johns Hopkins University)

PPHST: Public Papers of Harry S. Truman

PPS: Policy Planning Staff (U.S. Department of State)

PRC: People's Republic of China

ROK: Republic of Korea ('South Korea') 
SAC: Strategic Air Command

UN: United Nations

USAF: United States Air Force

USSR: Union of Soviet Socialist Republics

When referring to members of the United States Congress, standard format noting political allegiance_-'D' signifying the Democratic Party and 'R' signifying the Republican Party—and state represented — using the standard two letter notation format—will be used, for example: Senator Lyndon B. Johnson (D-TX). ${ }^{1}$

\section{A Note On Usage}

American spellings, such as 'Defense' shall be used when referring to US institutions or individuals, or quoting from US primary sources, for example: Secretary of Defense. In all other situations, UK spellings apply.

1 The abbreviations for all states can be found at the United States Postal Service website: http://www.usps.com/ncsc/lookups/usps_abbreviations.html 


\section{List of Key Figures}

Acheson, Dean, US Secretary of State January 1949-January 1953

Attlee, Clement, Prime Minister of the UK, July 1945-October 1951

Bradley, General Omar N., Chairman of the Joint Chiefs of Staff, August 1949-August 1953

Bush, Vannevar, physicist and US government science advisor

Clark, General Mark W., Supreme Commander, Far East, May 1952-July 1953

Churchill, Winston, Prime Minister of the UK, October 1951-April 1955

Collins, General J. Lawton, Army Chief of Staff, August 1949-August 1953

Eisenhower, General Dwight D., Supreme Commander NATO, December 1950-May 1952, US President, January 1953-January 1961

Jiang Jieshi (Chiang Kai-shek), President of the Republic of China (Taiwan), March 1950-April 1975

LeMay, General Curtis E., Commanding General, Strategic Air Command, October 1948-July 1957

Lovett, Robert A., US Secretary of Defense, September 1951-January 1953

MacArthur, General Douglas, Supreme Commander, Far East, July 1950-April 1951

McCarthy, Joseph, US Senator, January 1947-May 1957 
McMahon, Brien, US Senator, January 1945-July 1952, Chairman of the Joint Congressional Committee on Atomic Energy, 1949-1952

Mao Zedong (Mao Tse-tung), Chairman of the Communist Party of China, 1943-1975

Marshall, George, US Secretary of Defense, September 1950-September 1951

Morrison, Herbert, UK Secretary of State for Foreign Affairs, March 1951-October 1951

Nitze, Paul H., Director of the US Department of State Policy Planning Staff, January 1950June 1953

Oppenheimer, J. Robert, nuclear physicist and 'father' of the atom bomb

Pace, Frank Jr., US Secretary of the Army, April 1950-January 1953

Rabinowitch, Eugene, biophysicist and editor of The Bulletin of the Atomic Scientists

Rhee, Syngman, President of the Republic of Korea, July 1948-April 1960

Ridgway, General Matthew B., Commanding General, US Eighth Army in Korea, December 1950-April 1951, Supreme Commander, Far East, April 1951-May 1952

Rusk, Dean, US Assistant Secretary of State for Far Eastern Affairs, 1950-1952

Taft, Robert A., US Senator, January 1939-July 1953

Truman, Harry S., US President, April 1945-January 1953

Vandenberg, General Hoyt S., Chief of Staff, United States Air Force, April 1948-June 1953 
Van Fleet, General James A., Commanding General, US Eighth Army in Korea, April 1951July 1953

Walker, General Walton H., Commanding General, US Eighth Army in Korea, July 1950December 1950

Zhou Enlai (Chou En-lai), Premier of the Peoples Republic of China, October 1949-January 1976 


\section{Map of Korea}

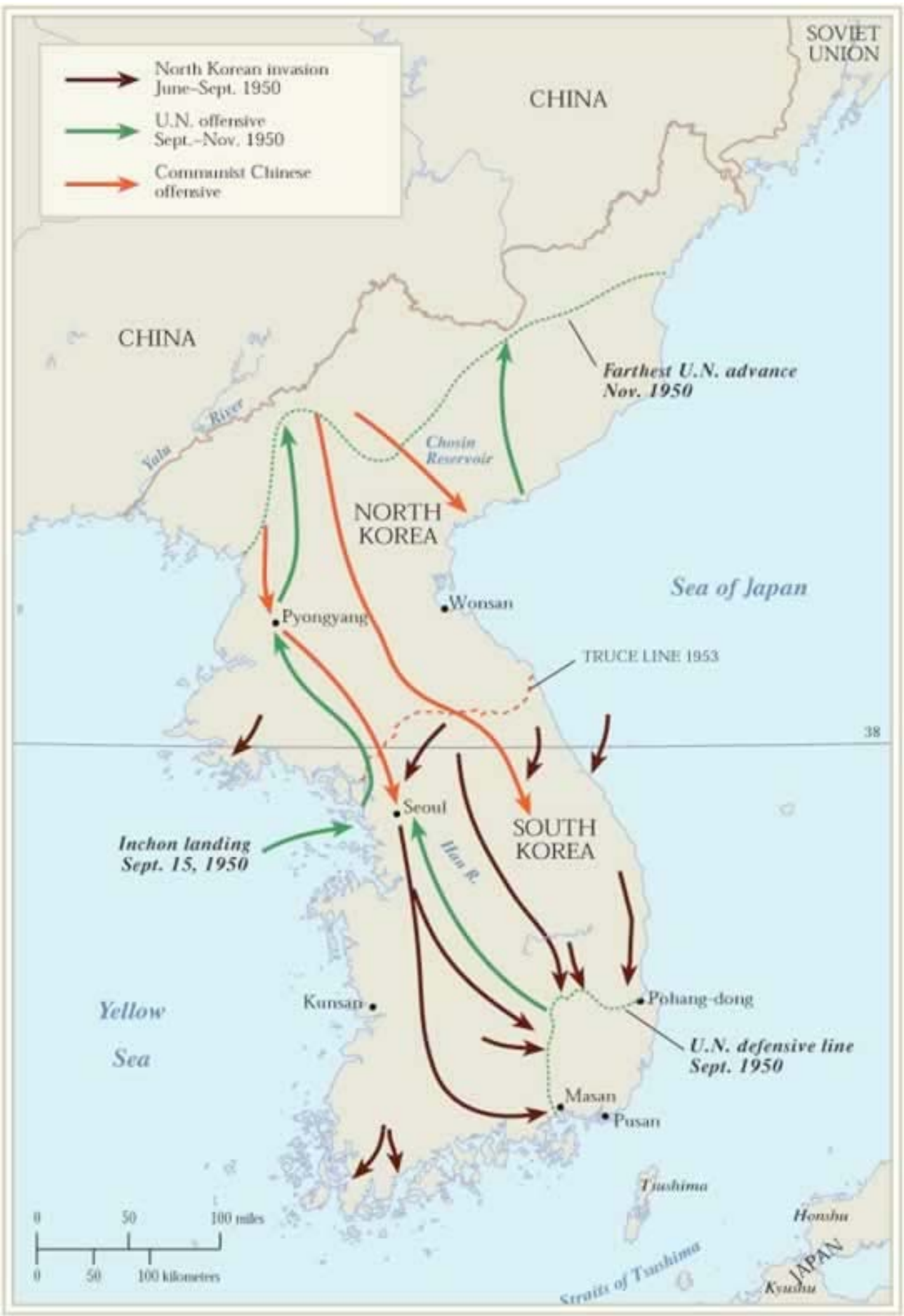

Source: http://nhs.needham.k12.ma.us/cur/wwII/07/p407/ndm/images/KoreanWarMap.jpg 


\section{Introduction}

In the National Air \& Space Museum Udvar-Hazy Center's vast hangar near Washington, DC sits the B-29 Superfortress 'Enola Gay', one of the most potent symbols of the atomic age. It is a permanent reminder of the beginning of forty-five years of paranoia and fear that dawned in August 1945 with the dropping of atomic bombs on Hiroshima and Nagasaki. When the Korean War began on 25 June 1950, B-29s still flew in service with the United States Air Force (USAF) and a sizeable minority were outfitted to deploy the atomic bomb. ${ }^{1}$ Korea was the Cold War's first major armed confrontation and as a result, it presented the first opportunity since Nagasaki for a US president to make a decision about using the bomb again in wartime. One of the main questions during the three years of bloody conflict was this: would the United States again deploy its ultimate weapon?

As the leader of the only nation to have used the atom bomb in wartime, President Harry S. Truman found himself in a curious position only three years into the Cold War. Would Truman decide to use the weapon again or would having used it before convince him not to? Certainly, a senior figure at the apex of the US political-military complex predicted that a mushroom cloud would rise above the battlefield as soon as US troops set foot on the Korean peninsula. ${ }^{2}$ Yet it was only at the very end of November 1950 that the President finally admitted to an insistent press that the use of the atomic bomb had always been under consideration as part of US planning in the Korean War. ${ }^{3}$ Why then, in light of the prior use at Hiroshima and Nagasaki, and the expectations of politicians, military leaders, and the general public, was the atomic bomb not used in the Korean War? That is the question that this thesis seeks to answer.

This thesis aims to understand the prevailing factors that influenced the decision making process regarding the non-use of atomic weapons in the Korean War. It explores the

1 The exact figures, as of January 1950, were 96 B-29s and 96 of the higher performance B-50 model able to carry atomic weapons. The USAF also had 34 of the much larger and longer-ranged B-36 bombers. See David Alan Rosenberg, 'US Nuclear Stockpile, 1945-1950', The Bulletin of the Atomic Scientists, Vol.38, No.5 (May, 1982), p.30.

2 Maxwell D. Taylor, Swords and Ploughshares: A Memoir, New York, 1972, p.134. General Taylor was then commanding US forces in Europe.

3 The President's News Conference, November 30, 1950, Public Papers of the Presidents: Harry S, Truman 1945-1953 (hereafter PPHST), HSTL, viewable on-line at http://www.trumanlibrary.org/publicpapers, accessed on June 17, 2009. 
reasons that ultimately determined the refusal by Truman to use the weapon, including the contributions made by the administration, the military, Congress, the scientific experts, the American public, foreign governments, and foreign public opinion to the debate about using the weapon. The thesis also places this debate within its historical context in the formative years of the Cold War, when the politicians and military leaders of the United States and the Union of Soviet Socialist Republics (USSR) developed the initial set of beliefs, interpretations of each other's motives, policies, strategies, and technologies that came to characterise the next forty-five years of confrontation. In doing so, this thesis critiques the various explanations for non-use put forward by historians and offers a new contribution to a debate which has yet to attract the same attention as the still ongoing controversy over the original use of the weapon on Japan.

\section{Historiography}

There is a small but detailed body of scholarship specifically relating to the topic of non-use in Korea. This is contained within specific analyses of non-use and more general works on the Cold War. A careful and considered analysis of the claims made in key texts and comparison with the available primary evidence will assist in enriching and expanding our understanding of the topic.

Of the specific analyses of non-use, Roger Dingman's paper 'Atomic Diplomacy During the Korean War' offered the most detailed interpretation and remains one of the seminal pieces of scholarship on the topic. ${ }^{4}$ Dingman characterised the use of the nuclear threat as a de facto bargaining chip during the conflict and concluded that nuclear weapons were not 'easily usable tools of statecraft that produced predictable results. ${ }^{15}$ He took a broadly institutionalist- seeing the various groups within the administration as more significant than individuals—and materialist—where material constraints such as a limited nuclear arsenal were significant—approach to the subject. This, while valid as far as it goes, could benefit from a more nuanced view of the individual participants and non-institutional actors.

Dingman's conclusions can be contrasted with those offered by Timothy J. Botti in Ace In The Hole; Daniel Calingaert in 'Nuclear Weapons and the Korean War'; Conrad C. Crane in

4 Roger Dingman, 'Atomic Diplomacy During the Korean War', International Security, Vol.13, No.3 (Winter 1988-1989), pp.50-91.

5 Ibid, p.91. 
'To Avert Impending Disaster' and specific sections of his American Airpower Strategy in Korea: 1950-1953; John Mueller in Retreat From Doomsday; and Nina Tannenwald in The Nuclear Taboo. ${ }^{6}$

Botti offered only a superficial examination of the topic and asserted that in the case of Truman, it was the fighting prowess of the US armed forces in Korea that obviated the need to make that fateful decision to use the atomic bomb. However, Botti ignored much of the pre-existing scholarship on the topic, such as the work of Calingaert and Dingman, rendering his work — which lacks substantive analysis of the personalities and issues-limited in its usefulness. As Barton Bernstein, a prominent scholar of nuclear issues, noted of Botti's work 'by relying heavily on narrative and by only infrequently providing explicit analysis, the volume does not directly explain why particular presidents chose not to use nuclear weapons."

Calingaert broadly paralleled Dingman's contemporaneous study in both approach and conclusions. In light of documentary evidence this thesis contests some of his conclusions such as that American policy-makers threatened employment of nuclear weapons in a 'conscientious and responsible manner'. ${ }^{8}$ I argue that discussions and considerations of the atomic bomb during the Korean War were far from 'conscientious and responsible': that US thinking was clouded by panic, fear, stresss, and personal rivalries. Calingaert also claims that all of the reasons for non-use were 'predicated upon its [the United States] limited war aims.' This thesis demonstrates that there were other factors contributing to non-use apart from war aims.

Mueller-also writing contemporaneously with Dingman—offered a broader theory of the post-World War II obsolescence of major war between developed countries. Major war has been rejected, he suggested, because it has become accepted as such a thoroughly unwise and repulsive idea. ${ }^{10}$ Mueller went further and suggested that nuclear weapons were the ultimate expression of this concept: obsolete tools useful only for a conflict which could not

6 Timothy J. Botti, Ace in the Hole: Why the US Did Not Use Nuclear Weapons, 1945-1965, Westport, 1996; Daniel Calingaert, 'Nuclear Weapons and the Korean War', The Journal of Strategic Studies, Vol. 11, No. 2 (June, 1988), pp.177-202; Conrad C. Crane, 'To Avert Impending Disaster: American Military Plans to Use Atomic Weapons During the Korean War', The Journal of Strategic Studies, Vol.23, No.2 (June, 2000), pp.7288; Conrad C. Crane, American Airpower Strategy in Korea, 1950-1953, Lawrence, 2000; John Mueller, Retreat From Doomsday: The Obsolescence of Major War, New York, NY, 1989; Nina Tannenwald, The Nuclear Taboo: The United States and the Non-use of Nuclear Weapons Since 1945, Cambridge, 2007.

7 Barton J. Bernstein, 'Review', The Journal of American History, Vol.85, No.1 (June, 1998), p.304.

8 Calingaert, 'Nuclear Weapons and the Korean War', p.200.

9 Ibid, p.177.

10 Mueller, Retreat From Doomsday, p.219. 
take place. ${ }^{11}$ He presented a compelling, but ultimately unconvincing argument on non-use, never offering a decisive statement on why the bomb was not used in Korea. John Lewis Gaddis sharply focused on one of the main flaws in his thesis: 'It fails to take into account a peculiar characteristic of the weapons that made them unique: the fact, that, because of Hiroshima, the full consequences of using the atomic bomb became apparent at the moment the world became aware of its existence. ${ }^{12}$ However, it is important to note that Mueller made a vital contribution to an analysis of this period through his work on public opinion, which shall be discussed shortly.

The final, and most recent, theory on non-use is that of the 'nuclear taboo', as proposed by Nina Tannenwald. Taking a new approach to thinking on non-use, Tannenwald argued that an evolving ethical and moral revulsion against using nuclear weapons since 1945 was a major component of non-use. This 'taboo' stigmatized nuclear weapons as an unacceptable source of force on the part of a state. ${ }^{13}$ Tannenwald argued that while this taboo cannot provide a complete answer as to why weapons were not used, it represents a majorand previously underestimated—component of non-use. Tannenwald also outlined a range of competing (but not always mutually exclusive) explanations of non-use, including deterrence; the uncertain long-term consequences of a use of nuclear weapons; a lack of military utility; and the obsolescence of major war. ${ }^{14}$ Tannenwald positioned the Korean War as the bedrock upon which the nuclear taboo was built, emphasising the moral and ethical aspects of non-use to provide a platform for further case studies such as the Vietnam War. Her thesis also utilises as evidence, but does not substantively engage with, the viewpoint put forward by Dingman.

By engaging with these key pieces of scholarship this thesis provides a finer understanding of the topic. Dingman and Tannenwald's works in particular provide the fundamental historiographical basis which any analysis of this issue must take account of. Both accounts are perceptive, but incomplete, as they take prohibitively narrow views of the subject. They do, however, provide a route-map for further investigation and analysis.

Alongside these specialist studies, many general works covering the Cold War or

11 John Mueller, 'The Essential Irrelevance of Nuclear Weapons: Stability in the Postwar World', in Sean M. Lynn-Jones and S. E. Miller (eds.), The Cold War and After: Prospects for Peace, Cambridge (MA), 1997, p.4569.

12 John Lewis Gaddis, 'The Essential Relevance of Nuclear Weapons', in John Lewis Gaddis, The United States and the End of the Cold War: Implications, Reconsiderations, Provocations, New York, 1992, p.109.

13 Tannenwald, The Nuclear Taboo, p.2

14 Ibid, pp.30-43. 
Korean War touch upon the issue of non-use. Despite not delving into the issue in any great detail, these volumes often offer useful and informative insights into certain issues. Richard K. Betts contributed to the debate in Soldiers, Statesmen and Cold War Crises arguing against the perception of the military being always more aggressive than their political masters, and placing this analysis in the context of significant Cold War policy decisions. ${ }^{15}$ Later, in Nuclear Blackmail and Nuclear Balance, he analysed the role that the balance of nuclear power played in the reactions of successive US administrations to key Cold War crises, and argued that the US use of nuclear threats was made without consideration of what would occur if their bluffing tactics failed. ${ }^{16}$

Three works by John Lewis Gaddis offer some key insights into non-use. In Strategies of Containment he posited that the war in Korea represented the initial implementation of the militarised containment policy laid down in National Security Council report 68 (NSC-68). ${ }^{17}$ Gaddis traced the origins of US nuclear threats in Korea to the asymmetrical response doctrine of meeting challenges to the containment policy with massive force. He offered a useful interpretation of the importance of NSC-68 and the policy of containment to the situation in Korea and to the debate between the various political figures and institutions.

In The Long Peace Gaddis investigated why the US and the USSR did not engage in a directly confrontational war during the Cold War. ${ }^{18}$ Gaddis analysed why the United States did not use nuclear weapons in the early part of the period despite having a virtual monopoly on them, either through sole possession of the weapons or of effective delivery mechanisms. He argued that US officials chose not to use the bomb as a result of the deterrent effect of Soviet power, material constraints on use, and the unique nature of the weapon itself. We Now Know offered a revision of previous analyses in light of the end of the Cold War, contending that the 'nuclear education' of Harry Truman was far in advance of many other significant actors. ${ }^{19}$

In Korea: The Unknown War, Bruce Cummings and Jon Halliday made the bold claim that certain statements made by Truman were not faux pas, but were carefully weighed threats. ${ }^{20}$ In particular, the authors referred to the press conference of 30 November 1950,

15 Richard K. Betts, Soldiers, Statesmen and Cold War Crises, Cambridge, MA, 1977.

16 Richard K. Betts, Soldiers, Nuclear Blackmail and Nuclear Balance, Washington, DC, 1987.

17 John Lewis Gaddis, Strategies of Containment: A Critical Appraisal of Postwar American National Security Policy, Oxford, 1982.

18 John Lewis Gaddis, The Long Peace: Inquiries into the History of the Cold War, Oxford, 1987.

19 John Lewis Gaddis, We Now Know: Rethinking Cold War History, Oxford, 1997, p.112.

20 Jon Halliday and Bruce Cummings, Korea: The Unknown War, London, 1988. 
where Truman made his famous comment regarding consideration of A-bomb use. Cummings and Halliday suggested that this was a deliberate and carefully planned statement. ${ }^{21}$ This thesis will contend that in their assertions, which also cover later operations related to tactical atomic planning, Cumings and Halliday were essentially wrong.

In The Wrong War, Rosemary Foot analysed the debate over expansion of the war and the tension it caused amongst those involved in the US political-military system. ${ }^{22}$ Foot also discussed how relationships between the United States and its allies were strained by events in Korea. According to Foot, the main reasons for not expanding the war were uncertainty over the Soviet reaction and a lack of enthusiasm on the part of allies. ${ }^{23}$

William Stueck, in Rethinking the Korean War, made the argument that democracies such as the United States find greater pressures, from domestic and foreign opinion, acting on them during moments of international crisis than totalitarian regimes. ${ }^{24}$ They are required to take more account of these pressures and nowhere is this better illustrated than in the issue of the atomic bomb. Detailed analysis of Stueck's argument requires a comprehensive comparative study which is beyond the bounds of this thesis. He did, however, provide a concise and comprehensive account of the diplomatic and strategic elements of the Korean War.

In order to analyse the state of public opinion and awareness of nuclear issues during the period 1950-1953, four works are particularly important. Paul Boyer's By The Bomb's Early Light offered insight into media and public opinion about atomic weapons. He also made the case (from opinion polls conducted at the time) that, in late 1951, a majority of Americans supported the use of nuclear weapons against military targets in Korea. ${ }^{25}$ This leads to two questions: does the large-scale evidence back up this assertion and what sources informed this state of public opinion?

Lawrence Wittner, in One World or None, viewed the period through the lens of the worldwide anti-nuclear campaign. ${ }^{26}$ He discussed not only the state of American public opinion but also the state of public opinion in key American allies such as the UK.

Steven Casey's Selling the Korean War made the case that, in the early days of the conflict

21 Ibid, p.123.

22 Rosemary Foot, The Wrong War: American Policy and the Dimensions of the Korean Conflict, 1950-1953, Ithaca, 1985.

23 Ibid, p.130.

24 William Stueck, Rethinking the Korean War: A New Diplomatic and Strategic History, Princeton, 2002.

25 Boyer, By The Bomb's Early Light, p.340.

26 Lawrence S. Wittner, The Struggle Against the Bomb, Vol.1: One World or None; A History of the Nuclear Disarmament Movement Through 1953, Stanford, 1993. 
there was concern over the creation of popular hysteria surrounding Korea and the making public of NSC-68's proposed massive defence build-up. ${ }^{27}$ He suggested that senior politicians were deeply concerned that if Korea was used as a means to 'sell' increased defence spending to the public, this could create a climate of fear regarding the explosion of a major war with the USSR which might lead to further calls for dangerous courses of pre-emptive action. ${ }^{28}$

John Mueller's War, Presidents, and Public Opinion offered a comparative study of public attitudes towards the Korean and Vietnam Wars, using a broad range of quantitative and qualitative data. ${ }^{29}$ This makes it, and other work by Mueller on public opinion, a useful source of data and analysis on domestic attitudes during the Korean War.

\section{Primary Sources, Memoirs, and Official Histories}

There are several key sources of primary documents related to the Korean War. One of the most useful, and readily available, of these is the US State Department's official history of foreign policy Foreign Relations of the United States (FRUS). The series 'presents the official documentary historical record of major US foreign policy decisions and significant diplomatic activity' and the material in it is vital to understanding the political and military debate on the atomic bomb in Korea. ${ }^{30}$ The volumes relating to the Truman administration have been exhaustively researched for detail relevant to this thesis. Due to national security and secrecy issues, the information contained within the FRUS series cannot be regarded as wholly complete, but certain documents can now be viewed on-line with redactions removed. These on-line sources also lead to another rich seam of primary documentation. The release of previously classified documents under the Freedom of Information Act (FOIA) and their subsequent digitisation has made many previously inaccessible sources available. Databases such as the Central Intelligence Agency FOIA Electronic Reading Room (CIA-FOIA) and the Digital National Security Archive (DNSA) are invaluable resources.

Research into a range of records relating to the Korean War period has also been carried out at the US National Archives and Records Administration (NARA) in College Park,

27 Steven Casey, Selling the Korean War: Propaganda, Politics, and Public Opinion, 1950-1953, Oxford, 2008.

28 Ibid, p.71.

29 John Mueller, War, Presidents, and Public Opinion, New York, 1973.

30 United States Department of State, 'Foreign Relations of the United States, US Department of State website, http://www.state.gove/r/pa/ho/frus, accessed on February 25, 2009 
Maryland. The information collected during this research has been expanded by additional documents obtained from the Harry S. Truman Presidential Library (HSTL) in Independence, Missouri. NARA and the HSTL provide relevant memos, reports, meeting transcripts, and letters which are unavailable through either FRUS or digital sources.

The records of the United States Congress have also been thoroughly researched. These collected volumes detail all remarks, speeches, and comments made in both the House and Senate. In addition, the appendices offer a valuable record of items entered into the Congressional Record by Congressmen and Senators.

It is important to note the information contained within the various official histories produced by various departments of the United States Government. Care has been taken not to assign undue significance to any interpretations or conclusions offered by official histories produced by various branches of the US government and military. The History of the Joint Chiefs of Staff, the History of the United States Army in the Korean War and the volumes of the History of the Office of the Secretary of Defense relating to the Korean War period have been examined. ${ }^{31}$ Written by official historians and with access to a vast array of primary source information, they are in many ways a comprehensive factual account of their topic yet they should not be considered as unbiased, presenting as they do the 'official' version of events.

Autobiographies and memoirs provide a substantial source of information on the period under study. Particularly illuminating are the memoirs of those directly involved in the decision making process. The Memoirs of Harry $S$. Truman are a substantial record of his time in office, which have been consulted to gain insight into the character of the man who, at least nominally, wrote them. ${ }^{32}$ Other key autobiographies include those by politicians such as Present At the Creation by Dean Acheson and From Hiroshima to Glasnost by Paul H. Nitze. ${ }^{33}$ Attention has also been paid to the memoirs of military leaders, including that most egotistical of autobiographies, the Reminiscences of General Douglas MacArthur. ${ }^{34}$ These have been analysed carefully, keeping in mind Arthur Marwick's warning that 'an autobiography will usually have

31 James F. Schnabel and R.J. Watson, History of the Joint Chiefs of Staff: The Joint Chiefs of Staff and National Policy, Vol.3: The Korean War, parts 1 and 2, Wilmington, 1979; James F. Schnabel, United States Army in the Korean War: Policy and Direction, the First Year, Washington, DC, 1972; Walter G. Hermes, United States Army in the Korean War: Truce Tent and Fighting Front, Washington, DC, 1966; Doris M. Condit, History of the Office of the Secretary of Defense: The Test of War, 1950-1953, Washington, DC, 1988.

32 Harry S. Truman, Memoirs of Harry S. Truman, Vol.2: 1946-52, Years of Trial and Hope, New York, 1986.

33 Dean Acheson, Present at the Creation: My Years at the State Department, London, 1969; Paul H. Nitze, with A.M. Smith and S. Reardon, From Hiroshima to Glasnost: At the Centre of Decision, A Memoir, New York, 1989.

34 Douglas MacArthur, Reminiscences, London, 1965. 
to be treated with even greater circumspection than the more straightforward primary document. ${ }^{35}$ The information provided by memoirs has therefore been carefully evaluated and compared with primary evidence in order to ascertain their validity.

Two particular sources have been utilised to gain an insight into public opinion on non-use of the atomic bomb. A selection of letters to major newspapers has been examined, providing a sample of public views on the issue. Obviously, this sample is not wholly representative and some extrapolation must take place. In order to amplify and back up the findings from letters, opinion poll data is also used to look at the broader picture of quantitative public opinion.

Finally, it should be noted that archival material from sources beyond the US have not been used in this thesis. Given the constraints of the MA thesis and the focus of the study on US attitudes and decision-making processes, this was the preferred approach.

\section{The Early Cold War}

Between the end of World War II and the outbreak of the Korean War the Cold War took shape with former allies glaring at each other across the globe. The United States was allied to the USSR when it dropped atomic bombs on Japan. By the time of the Korean War, the Soviets were the enemy and the potential targets of the US atomic arsenal. What had happened in between?

The 'Long Telegram' of 22 February 1946, penned by George Kennan, a relatively junior diplomat in Moscow, along with Kennan's anonymously published article 'The Sources of Soviet Conduct' (sometimes known as the 'Mr X Article'), served to lay out the foundations of US policy towards the USSR. ${ }^{36}$ Kennan believed that Soviet leaders needed to paint the outside world as hostile to the very existence of the USSR and its communist ideology to justify the continuance of their dictatorship. ${ }^{37}$ Furthermore, the US could not overthrow the Soviet regime but it could contain it. This analysis underpinned what became the 'Truman Doctrine' and the containment policy, wherein the United States attempted to prevent the

35 Arthur Marwick, The Nature of History, 3 $3^{\text {rd }}$ edition, London, 1989, p.200.

36 Walter LaFeber, The American Age: US Foreign Policy at Home and Abroad, 1750 to the Present, 2nd edition, New York, 1989, p.473; John Lewis Gaddis, The Cold War, London, 2007, p.29.

37 George Kennan (writing as 'X'), 'The Sources of Soviet Conduct', Foreign Affairs, Vol.24, No.4 (July, 1947), p.570. 
spread of communism wherever it might occur.

In Korea itself, the post-war division of the country into zones of US and Soviet influence, divided by an arbitrary line along the $38^{\text {th }}$ parallel, set the groundwork for the coming war. With the US backing the anti-communist President of the Republic of Korea (ROK), Syngman Rhee and the USSR supporting the Stalinist regime of Kim Il-sung in the North, the possibility of rapprochement was slim.

When in early 1947, the UK-crippled by the continuing economic burden of World War II-withdrew support from the right-wing Greek government in its fight against a communist insurgency, the Truman administration saw it as the ideal opportunity to declare its containment policy. ${ }^{38}$ By placing the policy in the public consciousness as a bold stand against the evils of worldwide communism, containment - as expressed in the Truman Doctrinegained both political and public approval by showing the US as strong and willing to stand firm against the Soviet Union and its satellites. The connection between the two was important: communism was positioned as a threat to 'the American way of life'-stopping communism resonated with the public, many of whom felt remote from events overseas and a policy such as containment.

The Korean War should be viewed in the context of Cold War events through the preceding three years. From 1947, the Truman administration faced a series of challenges, some of which brought the question of atomic weapons to the fore. The most tense of these challenges, the Berlin Blockade of 1948-1949-when the Soviet Union closed land communication between western Germany and the western-controlled sectors of Berlin-led to the most famous logistical exercise of all time: the Berlin Airlift. The task of supplying the western sectors of the city by air was immense and the success of the operation was by no means guaranteed. Banking on the atomic bomb as a means to influence Soviet policy, Truman ordered the movement of B-29s to England. In public, there was no acknowledgement of exactly which model of B-29 they were. There was some speculation that they were the 'Silverplate' versions, able to carry atomic bombs and that the US was readying its arsenal in case Stalin went too far with the blockade. Official press releases categorised the bombers as 'atomic capable' even though they were in reality incapable of

38 LaFeber, The American Age, pp.476-477. 
carrying the current versions of the A-bomb. ${ }^{39}$ In an atomic bluff the Truman administration did nothing to suggest to the Soviets that they were not atomic bombers. ${ }^{40}$ The threat of the A-bomb was there, even if the threat was veiled.

The question of the atomic bomb and its position within US foreign policy was brought into sharp relief by two major shocks to US strategic calculations in 1949. Firstly, the American atomic monopoly ended on August 29 when the USSR tested its first nuclear weapon. The Western world was shocked by this development, having thought that a workable Soviet bomb was at least two years away. ${ }^{41}$ America was still in a position of massive atomic superiority, but atomic monopoly had disappeared. The shock encouraged a group of leading scientists to brief Truman on an even more destructive weapon: the hydrogen bomb.

The 'super', as it was then known, was not a military but a psychological necessity. ${ }^{42}$ Not having the weapon would be a debilitating blow to American prestige, standing and deterrent power, even if the weapon was, in the traditional terms of war, a completely irrational weapon, problematic in terms of actual utility due to its unprecedented destructive power. ${ }^{43}$ The development of the 'super' troubled scientists, politicians, and the military. Figures such as the renowned scientific head of the Manhattan Project, J. Robert Oppenheimer, opposed the development on moral, rather than scientific grounds. Opponents argued there could be no reasonable use for weapons of such immense destructive power.

Secondly, in October, US prestige received a further blow when Mao Zedong (Mao Tse-tung) proclaimed the People's Republic of China (PRC) as the American-supported Nationalists under Jiang Jieshi (Chiang Kai-shek) fled from the mainland at the end of the Chinese Civil War. The Cold War was now firmly a global conflict, spreading into East Asia and towards vital US interests in Japan. In Washington and across the US, the reaction to the 'loss' of China was immediate and vitriolic. It represented, so the critics said, a major foreign policy disaster and a failure for Dean Acheson, who had become Secretary of State that same year. The creation of the PRC also meant that the communist Democratic People's Republic of Korea (DPRK) now had a powerful ally on its northern border.

39 Gregg Herken, The Winning Weapon: The Atomic Bomb in the Cold War, 1945-1950, Princeton, 1988, p.259.

40 Tannenwald, Nuclear Taboo, p.109.

41 Richard G. Hewlett \& Francis Duncan, Atomic Shield: Volume 2 of a History of the United States Atomic Energy Commission, University Park, 1969, p.369.

42 Gaddis, The Cold War, p.61.

43 Gaddis, The Long Peace, p.113. 
Less shocking to US foreign policy, but nonetheless significant, was the Stockholm Peace Appeal. Initiated on March 15, 1950 by the Permanent Committee of the Partisans of Peace, the appeal-prompted in part by Truman's announcement that the US would be proceeding with development of the hydrogen bomb-called for the outlawing of all forms of nuclear weapon. Backed as it was by the communist powers, the appeal—with an alleged 500 million signatories - was judged in the US at least as little more than a Soviet campaign to de-legitimise the United States' atomic superiority, but had considerable appeal to public opinion elsewhere. $^{44}$

Meanwhile in the United States anti-communism and 'red-baiting' reached new heights as 1950 dawned, with not even the highest office holders immune from the barbs of innuendo and condemnation. Calls for Acheson's dismissal echoed across the United States as he refused to turn his back on convicted spy Alger Hiss. ${ }^{45}$ Foremost amongst those whipping up hysteria was the man who lent his name to shrill anti-communism: Senator Joseph McCarthy (R-WI). His speech on February 9, 1950 at Wheeling, West Virginia shot this previously obscure Wisconsin Republican into the national limelight. His claim that there were 205 (later revised downwards and to fluctuate wildly thereafter) card-carrying communists in the State Department and that Acheson knew who they were received nationwide media attention alongside his claims that the 'loss' of China was directly attributable to Soviet infiltration. ${ }^{46}$ Again, this put the Truman administration, who had positioned themselves as anti-communist, in the ironic position of being attacked for not being anti-communist enough.

Throughout the early Cold War there was a determined effort to try and make sense of both Soviet intentions and the appropriate American response in an atomic age. The end result of this was NSC-68, the most significant policy document of the Cold War. A committee chaired by Paul H. Nitze, Kennan's replacement as head of the State Department Policy Planning Staff (PPS), drafted NSC-68. This document steered the policy espoused by Kennan in 'The Sources of Soviet Conduct' away from methods utilising negotiation to focus on military preparedness and nuclear re-armament as the cornerstone of US policy. ${ }^{47}$ It stated

44 The appeal and its influence are discussed at length in Wittner, One World or None, p.182-186, and elsewhere within that volume.

45 David Caute, The Great Fear: The Anti-Communist Purge under Truman and Eisenhower, New York, 1978, p.37.

46 NA, 'M'Carthy Attacks Acheson on Reds', Los Angeles Times, Feb 12, 1950, p.11; NA, 'M'Carthy Insists

Truman Oust Reds', New York Times, Feb 12, 1950, p.5.

47 LaFeber, The American Age, pp.505-506. 
that the USSR was dependent on military force in order realise its goals, goals that made the Soviet system:

wholly irreconcilable with ours, so implacable in its purpose to destroy ours, so capable of turning to its own uses the most dangerous and divisive trends in our own society, no other skilfully and powerfully evokes the elements of irrationality in human nature everywhere, and no other has the support of a great and growing centre of military power. ${ }^{48}$

According to the authors, the US must meet that system with its own military power, requiring a vast increase in annual defence spending. A substantial part of this budget would go towards expanding the size and power of the atomic arsenal, through increased production and the hydrogen bomb project. Despite being initialled by President Truman in April of 1950, NSC68 did not become official policy until September of that year. Before this happened, a major event apparently showed the accuracy of the committee's analysis: the Korean War.

\section{Approach}

In order to analyse the calls made for and against use of atomic weapons in Korea, this thesis examines the role of a wide range of individuals, organisations, and interested groups. Each chapter of this thesis focuses on a particular phase of the Korean War, taking into account the political and military debate within the Department of Defense, the Department of State, the National Security Council (NSC), in meetings of the Joint Chiefs of Staff (JCS), the role of Congress, the influence of American allies (in particular the UK), and world opinion, and the role of public opinion within the US. ${ }^{49}$ This thesis explores the issues raised in these debates, namely material considerations — such as battlefield conditions- the impact on the international image of the US, fear of global war, and the evolving nature of American Cold War foreign and atomic policy, particularly as promulgated in NSC-68. When Chinese forces entered Korea during November of 1950, the Truman administration also needed to confront the issue of what would happen if the bomb were used against Chinese

48 NSC-68 'United States Objectives and Programs for National Security', April 7, 1950, DNSA, p.9

49 The National Security Act of 1947 established both the JCS and NSC. The JCS is made up of the professional heads of the four branches of the United States military (Army, Marine Corps, Navy and Air Force) and advises the civilian government on military matters. The NSC is a forum for senior members of the government to consider matters of national security and foreign policy. For more on the creation, evolution and issues surrounding the JCS and NSC, see Amy Zegart, Flawed by Design: The Evolution of the CLA, JCS, and NSC, Stanford, 1999. 
targets. All of these questions entered into the complex and often fraught discussions regarding atomic weapons and the 1950-1953 war.

Firstly the thesis focuses on those who could have ultimately made the decision, the senior figures in government. Having been accused of 'losing' China to the communists, the Truman administration now had a chance to take a firm stand against communism in Asia. With the catcalls of political enemies at home still ringing in the ears of cabinet membersespecially Truman and Acheson-there was a powerful motivation for regaining the upper hand in that area of the world and demonstrating the strength of American foreign policy with a decisive 'win'. The policy of containment, as outlined by Kennan and given a martial twist by NSC-68, involved maintaining a strong buffer of allied states to resist the spread of communism. The Korean War was the first real test of containment and instrumental in setting US policy for the conduct of the Cold War and thus was watched closely by the rest of the world.

The dismal military situation in Korea was obviously of great concern to Truman and his administration. Since tanks, planes, and infantry did not succeed in securing a decisive victory in Korea, why not use another weapon to achieve success? At times in public, such as on November 30, 1950, it appeared that Truman might use the A-bomb, therefore this thesis determines whether his claim of giving 'consideration' to its use was a sign of bold brinkmanship, indecision, or simple bluster under pressure. Entering into this is the influence of personality on the formulation of non-use. This will be examined particularly as it applies to Truman and the stressful mental situation he found himself in, conflicted by his horror at what the atomic bomb could do and the knowledge that it was the cornerstone of US defence against the communist threat.

This thesis examines key officials involved in the political decision making processes and how they influenced the development of the Korean situation. For example, it analyses the positions of Dean Acheson and George Marshall-who occupied the position of Secretary of Defense from September of 1950 to September of 1951-and how they influenced presidential opinion. It also ascertains how other influential policy planners including Kennan and Nitze contributed to the debate. Such senior figures, up to and including Truman, were subject to accusations of 'appeasement' by their domestic political opponents. What effect did these accusations, with all the weight of recent history behind 
them, have on the administration?

Senior military figures also influenced the decision making process, from the JCS down through the various service heads to battlefield commanders controlling the war. An impressive line-up of military experience, much of it stemming from heroism and victory on the battlefields of World War II, participated in the debate. As the general for whom the atomic bomb had led to his elevation to de facto ruler of Japan, Douglas MacArthur was unlikely to be squeamish about using the bomb. The aggressiveness of MacArthur, coupled with his almost legendary stature in the US at the time, makes him the best known military figure of the war. It has often been asserted that MacArthur was heavily pro-use and this thesis examines this claim in some detail.

Generals other than MacArthur-whether on the battlefield, in Tokyo, or in Washington-also exerted an influence on non-use. General Matthew B. Ridgway, who replaced MacArthur upon his relief from command in April of 1951, brought a notably different set of priorities and personal characteristics to the battlefield. His assumption of command saw changes not only in the conduct of the war but also in the relationship between the administration and the military in Korea. Chairman of the JCS and famed war hero General Omar Bradley forcefully and consistently expressed his concerns, standing up to the likes of General Hoyt S. Vandenberg, the pro-atomic bomb Chief of Staff of the USAF. Did US commanders such as Bradley, Ridgway, and Vandenberg see the destructive power of the bomb as a way of 'saving face' against an enemy they had grossly underestimated, simply another weapon in the military arsenal, a weapon to be employed in the same way as artillery, tanks and bombers, or a step too far in a 'limited war'?

Military theoreticians also devised plans and prepared studies to analyse the potential tactical implications of atomic weaponry, working on an evolving theory of the atomic bomb as a battlefield tool, rather than just a city-destroying strategic weapon. The evolution of the atomic bomb as a tactical instrument was something that gained pace during the Korean War and moved from being purely of military concern, to being of interest to politicians and the public. This thesis therefore examines the distinctions made between tactical and strategic use and how this division affected the debate and decision making process.

Congress also took a deep-seated interest in the Korean War and the use of atomic weapons. The claim that atomic bombs had ended World War II and saved American lives 
could be readily applied to the Korean case. Certain Congressmen and Senators vociferously called for atomic weapons usage, most notably Lloyd Bentsen (D-TX), Owen Brewster (RME), and Overton Brooks (D-LA). This thesis assesses the impact of these pronouncements. It is just as important to look for evidence of other Congressmen's and Senators' opposition to using the weapon, for example the views expressed by the influential head of the Joint Congressional Committee on Atomic Energy (JCAE), Brien McMahon (D-CT), to see what role Congress may have played in the ultimate decision.

Scientific advisers such as Vannevar Bush and the publicly recognised atomic scientists like J. Robert Oppenheimer took positions on the matter of nuclear weapons use. It is important to determine how their views on the impact and effects of atomic weapons may have influenced the decisions made by Truman and his advisors. The influence of organisations and individuals on debate is taken into account, examining the views of The Bulletin of Atomic Scientists (hereafter referred to as The Bulletin) and notable individuals from within the scientific community. ${ }^{50}$ This includes the civilian Atomic Energy Commission (AEC) and its leading figures such as David E. Lilienthal and Gordon E. Dean. It will also assess the extent to which scientific experts' views were able, through the media, to influence public opinion on the use of atomic weapons. The Bulletin warrants special attention due to its origins and contributors. As a publication created and endorsed by scientists involved in the Manhattan Project, it represents a forum for the opinions of individuals with a very deep involvement in nuclear science and nuclear issues.

It is vital to examine the international response in order to place the US decision making process in the context of the developing world situation. After all, the US conducted the war in Korea under the auspices of the United Nations (UN) as a 'police action', with strong support from key European allies such as the UK. Whether or not to use the weapon was, therefore, a decision that the United States could not make in isolation. After the dramatic press conference of November 30, 1950, where Truman stated that the use of atomic weapons in Korea had always been 'considered', Prime Minister Clement Attlee hastened across the Atlantic in a state of some alarm, hoping to prevent the Korean conflict from going

50 The Bulletin of the Atomic Scientists was established in 1945 by scientists involved in the Manhattan Project to provide information on atomic energy issues and promote public understanding of the dangers posed by nuclear warfare. The magazine has been in continuous publication since then. 
atomic, doing so with the cheers of Parliament ringing in his ears. ${ }^{51}$ This thesis explores the extent to which Attlee's visit, and the joint US-UK communique that followed, created constraints on US use of the A-bomb. It also examines the influence of other allies and international opinion in creating a positive or negative response to the potential use of the bomb.

Finally, this thesis examines debate that took place in the American media by analysing how the news media presented opinions on the bomb and its potential for use in Korea. A review of key media evidence from the period has been undertaken in order to establish the level of public discourse regarding the use of nuclear weapons in the Korean theatre. This analysis pays particular attention to three major news organs: the New York Times, the Washington Post, and the Chicago Tribune. Careful consideration will be given to the framing of the issues and how the various media outlets presented the issues to their readership. If certain titles gave prominence to atomic advocates, how was this presented and editorialised? Furthermore, how were those who made statements against the bomb portrayed in the media? Linking this in to the prevailing anti-communist hysteria, were bomb advocates portrayed as patriotic, loyal Americans and those who opposed its use depicted as somehow weak or unAmerican?

One area which this thesis will not focus on is the debate over civilian versus military control of the atomic stockpile. The issue of control of the nuclear arsenal impinges in a small way on the story of non-use, but it is not central to it and it is not a debate which can be done justice when subsumed into an examination of non-use. ${ }^{52}$

This wide-ranging analysis and investigation of the debate among the highest levels of government, the military, civilian officials, foreign allies and the public provides a more solid basis than any yet made for an explanation of why the US did not use atomic weapons in Korea, when it had the scientific, political, and military capability to do so.

51 Dean Acheson, The Korean War, New York, 1971, pp.84-85.

52 For a thorough account of the struggle between civilian and military groups for control of the nuclear arsenal in the United States, see Peter Douglas Feaver, Guarding the Guardians: Civilian Control of Nuclear Weapons in the United States, Ithaca, 1992. Roger M. Anders' 'The Atomic Bomb and the Korean War: Gordon Dean and the Issue of Civilian Control', Military Affairs, Vol.52, No. 1 (January, 1988), pp.1-6, also provides an account of the tension between the AEC (in particular its Chairman, Gordon E. Dean), the Truman administration and the military. 


\section{Structure and Aims}

This thesis consists of five chapters, covering the period from the June 25, 1950 outbreak of war until the January 1953 departure of Truman from office. Rather than focusing on a series of individual case studies, this thesis will examine the whole of the period from June 1950 to January 1953.

Each chapter is sub-divided into two key areas: the views of the 'insiders'-those at the highest levels of the government and military systems — and the views of the 'outsiders' Congress, other nations, scientists and the general public. Of primary concern is the decisionmaking process that took place within the 'insider' group. Also important, but of lesser influence on the process are those in the 'outsider' group.

The first chapter focuses on the period from the outbreak of the Korean War to just before the major Chinese intervention on November 28, 1950. The shock of the North Korean invasion and the UN response to the communist aggression created an atmosphere in which calls for immediately atom bombing could be made. This chapter examines how influential these calls were and how patterns were set for the future.

Chapter Two focuses on the days immediately after the Chinese intervention and examines in detail the reaction to President Truman's comments that use of the atomic bomb was being 'considered'. This period offers an opportunity to examine the reaction not only of the US media, but also the reactions of allies and non-aligned nations. As this chapter examines a very confined period of time, it adopts a slightly different structure, moving back and forth between the 'insider' and 'outsider' groups.

Chapter Three examines the three months from mid-December 1950 to March 1951, a period often overlooked in the existing historiography. This time is significant because it allows detailed examination of the influence of the individual, in this case General Matthew Ridgway, on the course of events. This period also serves to demonstrate continued US thinking on the atomic issue and the evolution of awareness of the subtleties of atomic diplomacy on the part of senior officials.

Chapter Four examines the months of April, May and June 1951, when Truman took the decision to move complete nuclear weapons beyond the borders of the United States for the first time since 1945. This coincided with the dismissal of Douglas MacArthur from his commands and an extreme fear of a combined Sino-Soviet assault. This chapter examines the 
effect on these changes on US atomic policy relating to Korea.

Chapter Five analyses the final eighteen months of the Truman administration's tenure in charge of the Korean War. It demonstrates that nuclear planning and the evolution of nuclear doctrine continued until the very last days of the administration. This thesis will not cover the last six months of the war, when the Eisenhower administration took charge. The new administration brought an entirely different set of experiences and approaches to the nuclear issue and Eisenhower did not have Truman's singular experience of ordering atomic use.

Chapters Three and Five in particular cover time periods that have received scant attention in the existing scholarship. By examining these periods in detail, it throws a sharper light on the whole picture of non-use during the Korean War.

Through these chapters, this thesis examines the totality of the Truman administration experience relating to atomic issues in Korea. It demonstrates that considerations of how, why, and when to use atomic weapons were continuous through the Korean War. This thesis examines the evidence and challenges the existing scholarship, demonstrating that aspectssuch as accusation of appeasement directed at the Truman administration-have been undervalued in previous studies. Rather than simply examining a limited selection of case studies (as in the work of Dingman) or viewing Korea solely as the foundation of an emerging nuclear taboo (as in the work of Tannenwald), it analyses the entire period of the Truman administrations involvement in Korea. Not only does this allow a more nuanced view, it also allows a re-examination of the role of key figures and their influence on the decision making process.

Non-use of the atomic bomb in Korea is a topic of wide-ranging importance. The outbreak of the Korean War helped to set US policy for the Cold War and allowed the proposals contained in NSC-68 to become concrete operational policy. Yet in the face of this militarisation of the US stance towards the USSR, Korea also established a new paradigm of nuclear non-use when there was wide expectation that nuclear weapons represented the new face of warfare. Why this came about is vital not only to an understanding of the conflict itself but it is also pivotal in understanding the course of the Cold War as a whole. Through the examination of existing theories and primary sources this thesis tells the full story of why 
an American president who had previously unleashed the atomic bomb in war chose the path of restraint and set a pattern whereby the nuclear sword has since remained sheathed. 


\section{Chapter 1: 'A Peculiar Monster'}

Just after ten p.m. on 24 June, 1950, Harry Truman received a telephone call from Secretary of State Dean Acheson. ${ }^{1}$ The President had taken a weekend away from the hustle and bustle of Washington to deal with some family business. ${ }^{2}$ Acheson informed Truman of an attack across the 38th parallel by communist North Korean forces, the decision to request an immediate meeting of the UN Security Council and the preparation of plans should US action be required. ${ }^{3}$ Truman's relaxed family break had ended and three years of war in Korea had begun.

On account of the Soviet boycott of the UN Security Council that left the USSR absent from the vote on the June 27 resolution to intervene in Korea, the United States found itself leading an ad-hoc coalition against a determined foe backed by the communist powers. The main platform of US foreign policy was to show willingness to act against communist aggression and aid the victims in their fight against oppression. Korea presented an ideal opportunity to demonstrate that willingness (there was a sneaking suspicion that Korea might just be a ruse, a feint to draw attention away from the far more valuable and vulnerable battleground of Western Europe.) If a stand were not taken in Korea, what would the future hold?

In addition, intervention in Korea would demonstrate to the American people that the Truman administration was not 'soft' on communism. Stung by accusations that their weakness had cost them China and allowed Soviet moles to infiltrate to the highest levels of government, Korea offered an opportunity to be bold and decisive. That the Truman administration was instrumental in inculcating in the American people the idea that communism was the insidious enemy_at home with 'reds under the beds' and abroad with the evil Soviet regime poised to crush freedom and democracy — was an irony lost on many of its critics.

The initial stages of the war proved disastrous for the forces of the ROK and, shortly

1 Although the war in Korea began on June 25, the time difference meant that in Washington it was June 24 when Truman was alerted.

2 Truman, Memoirs, Vol.2, pp.331-332.

3 Acheson, Present at the Creation, pp.402-404. 
thereafter, the UN. As the DPRK divisions smashed across the $38^{\text {th }}$ parallel, the ROK army wilted. The first US forces committed to Korea were woefully ill-equipped and under-prepared and were driven back by the determined North Korean assault. By August the UN armies had been forced into a tiny perimeter surrounding the southern port city of Pusan. A dogged defence, aided by air superiority, allowed them to retain this toehold on the peninsula. In midSeptember UN forces commanded by Douglas MacArthur, took the offensive. A daring amphibious assault at Inchon turned the war around and put the communist forces on the defensive. From then until November, the UN reversed the North Korean attack and rolled steadily towards, and past, the 38th parallel.

The existing scholarship on this period is either very institutionally focused (Dingman), limited in its coverage (Tannenwald and Calingaert) or lacking in substantive analysis (Botti). Therefore, this period is explored in some detail, examining not only matters of institutional politics and the role of key individuals, but also the position of the general public, foreign nations, and the scientific community in order to give a detailed, but full, picture of the period.

This chapter examines the five-month period of the Korean War from the opening attack by the DPRK to just prior to the major intervention by PRC forces on November 28, 1950. It looks at the calls to use the A-bomb that resulted from the outbreak of the fighting and analyses this critical early phase of the war when confusion, fear and uncertainty clouded the atmosphere in Washington. In this chaotic opening phase of the conflict, what were the factors that caused the United States to exercise restraint?

\section{The New Paradigm of Limited War}

To senior planners, the military situation in Korea offered a fundamentally different paradigm. According to George Kennan, the concept of 'limited war', a war whose goal is not complete destruction or subjugation of the enemy, especially under the auspices of an international body was something alien, even repugnant, to US strategic thinking. ${ }^{4}$ Both world wars had been wide-ranging, hugely destructive global conflicts involving millions of men and vast areas of land. From the Great War onwards it became axiomatic that a modern war was

4 George F. Kennan, Memoirs 1950-1963, London, 1973, p.95. 
total war, incorporating every resource available to the combatants. ${ }^{5}$ In World War II, longrange missiles, large-scale fire-bombing of civilian populations, and the atomic bombing of two Japanese cities, were accepted as expressions of that axiom.

The United States had to learn about limited war through practice, rather than theory. While America maintained a nuclear monopoly or, after August 1949, massive supremacy, there was no real reason to conclude that war would be anything other than 'all or nothing.' General Matthew Ridgway, for example, was one soldier who realised that Korea represented something fundamentally different, as he later reflected:

The concept of limited war was yet to be recognised. And our people found it easy to persuade themselves that they might fight and win any war without ever setting their feet on hostile ground, doing it all through air and naval power and the nuclear bomb. ${ }^{7}$

The conflict in Korea was limited by a range of factors: geography, weapons, participation, and choice of targets. ${ }^{8}$ As the first true test of containment, Korea also represented the first real opportunity to develop the theory of limited warfare that was essential to enacting a militarised strategy as envisaged by NSC-68 and had, as will be demonstrated, important implications for the use or non-use of the atomic bomb.

\section{INSIDERS}

\section{Opening Discussions}

The issue of the atom bomb was raised on June 25, 1950 at the very first Korean War meeting between Truman and his closest advisors. Truman asked USAF Chief of Staff General Hoyt S. Vandenberg if it was possible to knock out Russian bases in the Far East. Vandenberg responded that it could only be achieved with atomic bombs.' The conversation moved swiftly on apart from a brief Presidential order that the Air Force should prepare

5 Bernard Brodie, Strategy In the Missile Age, Princeton, 1965, p.307.

6 Ibid.

7 Matthew B. Ridgway, The War In Korea, London, 1968, pp.228-229.

8 Morton H. Halperin, 'The Limiting Process in the Korean War', Political Science Quarterly, Vol.78, No. 1

(March, 1963), pp.13-16; Brodie, Strategy In the Missile Age, p.251.

9 Memorandum of Conversation, June 25, 1950, FRUS 1950, Vol.7, pp.159. 
contingency plans to annihilate all Soviet air bases in the Far East. ${ }^{10}$

Plans to use the A-bomb in the Far East were coloured by the knowledge that the US nuclear stockpile was by no means as big as many people believed, amounting to approximately three hundred complete bombs and around six hundred non-nuclear bomb assemblies. ${ }^{11}$ Few who knew of this thought that this was a large enough arsenal to guarantee victory if a wider war broke out, a widespread fear at the time. The stockpile itself was controlled by the civilian AEC and the Korean War represented another stage in an ongoing struggle for control of the atomic stockpile, a struggle between the military and the Department of Defense on one hand and the AEC on the other.

In responding to North Korean aggression, the US developed its strategy on the assumption that the war was part of a Soviet plan of expansion or the opening gambit in a general world war. ${ }^{12}$ On June 29 the administration had some limited relief from a Soviet note that, although blaming South Korea for precipitating the invasion, indicated to no less an authority than Kennan that the USSR declined to involve itself directly. ${ }^{13}$

At the same meeting it was opined that if Manchuria-in north-eastern China-were bombed with conventional weapons, the US would have reduced its capability to use atomic bombs in the future. ${ }^{14}$ This brief mention of the atomic bomb was again swiftly passed over in favour of discussion on broader matters. On the same day as this meeting, a journalist asked Truman if he would use the bomb in Korea. He answered with a terse 'No comment. ${ }^{15}$ A month later, under similar circumstances, he was again asked, in light of pre-war statements that he would not hesitate to use the atomic bomb in cases of aggression, whether he was considering such a step? This time the answer was an unequivocal 'No.'

Truman was, despite the vague reassurance of the Soviet note, Kennan's interpretation, and other reports, worried that the events in Korea might precipitate a more general war. ${ }^{17}$ According to his memoirs, written in 1956, the thought of outright war with the

10 Ibid, p.160.

11 Rosenberg, 'US Nuclear Stockpile', p.26

12 Halperin, 'The Limiting Process in the Korean War', p.16.

13 Memorandum of National Security Council Consultants' Meeting, June 29, 1950, FRUS 1950, Vol.1, p.327.

14 Ibid, p.328

15 Press Conference of June 29, 1950, PPHST, accessed on 3 July, 2009.

16 Press Conference of July 27, 1950, PPHST, accessed on 3 July, 2009.

17 For example, see NSC-73, 'The Position and Actions of the United States With respect to Possible Further Soviet Moves in the Light of the Korean Situation', July 1, 1950, DNSA. 
USSR was foremost in his mind at all times and so every decision that he took in connection with the fighting in Korea was taken to prevent the outbreak of global war. ${ }^{18}$ His concern for global conflict was demonstrated well before Korea. In his private diary entry from September 13, 1948, during the Berlin Blockade, he confided that he had the terrible feeling that, after meeting with a cavalcade of senior advisers, the world was very close to war. In a poignant three word sentence, he declared 'I hope not. ${ }^{19}$ In conversation with David Lilienthal—-then head of the AEC - in February of 1949 he commented candidly 'Dave, we will never use it [the A-bomb] again if we can possibly help it. But I know the Russians would use it on us if they had it.'20

Historian S. David Broscious argued that Truman was mired in the middle of two conflicting sets of assumptions regarding nuclear weapons. On one side there was the feeling that nuclear war carried with it the genuine possibility of destroying not only the United States but the entirety of civilisation. ${ }^{21}$ On the other side, he was convinced that nuclear weapons formed the cornerstone of Western defence against the USSR. ${ }^{22}$ Caught between these two poles, Truman found himself in a paradoxical position of his own making, one that he resolved, according to Broscious, by engaging in 'cognitive procrastination' and declining to confront it. ${ }^{23}$

Truman's concern about expanded war seems, on the surface, strangely at odds with his request to the USAF on the first day of the war to prepare plans for potential strikes against Soviet air bases. On that hectic first day it was not clear whether Korea was a portent of a wider series of conflicts. While the worrying potential for an expanded war remained for a long time to come, Truman's immediate desire to have plans that utilised the atomic bomb can be explained by the opacity of the situation and the sense of panic prevailing in Washington. This thesis demonstrates that Truman remained conflicted by the atomic issue for the rest of his presidency.

18 Truman, Memoirs, Vol.2, p.345.

19 Robert H. Ferrell (ed.), Off the Record: The Private Papers of Harry S. Truman, New York, 1980, pp.148-149.

20 David E. Lilienthal, The Journals of David E. Lilienthal, Vol.2: The Atomic Energy Years, 1945-1950, New York, 1964, p.474.

21 S. David Broscious, 'Longing for International Control, Banking on American Superiority: Harry S. Truman's Approach to Nuclear Weapons', in John Lewis Gaddis, Philip H. Gordon, Ernest R. May and Jonathan Rosenberg (eds.), Cold War Statesmen Confront the Bomb, Oxford, 1999, pp.32-33.

22 Ibid.

23 Ibid. 
The records of debate and discussion through these weeks show that the fear that another major war had either broken out or was on the horizon served not to provoke those in power to use nuclear weapons, but emphasised the need for restraint. Truman at least understood his responsibility to avoid transforming a localised conflict into something far larger and more destructive. In his public statements, he displayed a determination to avoid precipitating a global conflict. ${ }^{24}$ The genuine fear that using the A-bomb would result in overt Soviet aggression either in the Far East or Western Europe served to stay the President's hand. This theme re-appeared throughout the course of Truman's tenure as President, and will be returned to in subsequent chapters. But while Tannenwald and others have noted Truman's personal revulsion at the thought of using the A-bomb again, the theory of cognitive procrastination put forward by Broscious adds a new layer to the scholarship on non-use.

In Korea the United States was at pains to demonstrate that, having been the driving force behind the resolution to act against the DPRK, its aims stood four-square behind those of the UN, i.e. the expulsion of North Korean forces from the South and a return to the status quo ante. An awareness that the A-bomb was fundamentally at odds with this line of reasoning was already beginning to creep into the decision making process. Was it possible to exploit the possession of the bomb without using it? The State Department wished to make the A-bomb the centrepiece of a psychological warfare campaign against the North. In a memorandum of July 6 it was boldly stated that the weapon's significance extended beyond using it for purely military purposes:

The extent to which the policing nations may go reaches beyond the mere question of whether the balance of military considerations justifies its use. Sociological, physiological, ideological, and even religious considerations are involved. The psychological effects of these considerations upon friend and foe alike must be weighed in advance. ${ }^{25}$

Here was a document that cut to the heart of the atomic debate, taking it beyond the military context in which it was often seen and placing it above all other weapons. The merest reference to the A-bomb required more than a simple discussion of its military potential. ${ }^{26}$ The

24 Steven Casey, 'White House Publicity Operations During the Korean War, June 1950 to June 1951', Presidential Studies Quarterly, Vol.35, No.4 (December, 2005), p.701.

25 'Psychological Considerations Involved in the Use of the Atom Bomb', July 6, 1950, Papers of Harry S. Truman, President's Secretary's Files, Truman Papers, HSTL, p.1. 26 Ibid. 
line between use and non-use was blurry and, as the report so perceptively stated, the psychological component needed assessment. No decision maker would suffer more from the psychological effects of the A-bomb issue than Harry Truman.

A memo, dated July 15, from Carlton Savage of the PPS further outlined factors key to any future discussion of the atomic bomb in Korea. Harking back to public opinion in the wake of the Hiroshima and Nagasaki bombings — where an overwhelming majority of those polled approved of using the atomic bomb against Japan-Savage stated that:

It seems reasonable to assume that the US public would sanction our use of the atomic bomb in Korea if the civilian and military leaders of the country believe this action essential for re-establishing peace and for saving the lives of American boys, and if the atomic bombs were used against military objectives without resultant wholesale destruction of civilians. ${ }^{27}$

After highlighting the importance of public opinion, the moral dimension of the bomb and the state of world opinion, Savage summarised the PPS argument that the bomb should not be used unless four specific circumstances were in place: Soviet or Chinese forces overtly entered the war; the weapon was essential to a decisive victory and such a victory could be won without depleting the limited nuclear arsenal; that non-combatants would not be subject to 'excessive destruction'; and UN permission was granted or that unilateral use outweighed any advantage obtained by gaining $\mathrm{UN}$ agreement. ${ }^{28}$

\section{The A-bomb's Military Potential in Korea}

Regardless of the State Department's desire to use the A-bomb as a 'psychological' weapon, the US military still viewed the weapon in strategic terms, especially as a potential deterrent to Soviet involvement in the war. On July 8 the head of Strategic Air Command (SAC) General Curtis LeMay was given preliminary orders to transfer a group of nuclearconfigured bombers to airfields in the UK, starting a process that replicated the B-29 bluff from the Berlin Blockade. More significantly, LeMay persuaded his political masters to send the B-29s complete with atomic bomb assemblies minus the nuclear cores, which would remain in the US under the control of the AEC. ${ }^{29}$ This decision was subject to high level

27 Carlton Savage, 'The Question of US Use of Atomic Bombs in Korea', July 15, 1950, RG59, NARA, p.1.

28 Ibid, p.3.

29 Dingman, 'Atomic Diplomacy', p.57. 
political horse-trading between British and American politicians, and senior military figures. ${ }^{30}$ Good relations between the two nations were vital to US strategic interests in Western Europe and, as would be the case throughout the war, the US could ill-afford to antagonise its junior, but still vital, ally.

The transfer of atomic-capable bombers to Britain was not the only such action taken in the face of the expanding crisis. On July 31 MacArthur received a message from the JCS informing him that the non-nuclear components of ten atomic bombs would be transferred to Guam by August $12 .^{31}$ Bomb components were also transferred into storage aboard the aircraft carrier Coral Sea. ${ }^{32}$ Nothing ever came of this strategic deployment as the bombers capable of carrying the nuclear weapons were rotated back to the United States in September 1950 after the amphibious landing at Inchon dramatically improved the military situation for the UN forces. ${ }^{33}$

Moving nuclear components to the Pacific tallied with MacArthur's belligerent and expansionist attitude, a stance he had adopted since his appointment as commander of the UN forces on July 7. Since 1945 he had been Supreme Commander, Allied Powers in Japan at the head of the occupation and rebuilding effort. In all but name he was Emperor of Japan and acted as an appropriately god-like figure, issuing commands from his Olympian domain in the former Dai Ichi Insurance building in Tokyo. He brooked no dissent and his subordinates enacted every dictate without question.

The Army also sought the views of the General. ${ }^{34}$ On July 13, for example, General Charles Bolte requested that his superior, Army Chief of Staff General J. Lawton Collins, discern MacArthur's opinion on 'Desirability employing atomic bombs in opns [operations] in FE [Far East] considering 1) Military effectiveness their employment in direct support ground combat opns; 2) restrictions if any that should be put on types of targets to be selected; 3) political and psychological implications of such employment. ${ }^{135}$

MacArthur had already begun to make suggestions of a more aggressive nature. In the

\footnotetext{
30 Ibid, pp.58-60.

31 Joint Chiefs of Staff to Commander-in-Chief Far East (MacArthur), July 31, 1950, Papers of Harry S. Truman, Naval Aide Files, HSTL.

32 Condit, History of the Office of the Secretary of Defense, p.463.

33 Crane, 'To Avert Impending Disaster', p.74.

34 Personal for General Collins from General Bolte, CSGPO, Dept. of the Army, Jr/OPS 091 Korea, July 13, 1950, RG319, NARA, p.1.

35 Ibid.
} 
event of Chinese intervention, his vision was to:

cut them off in North Korea...The only passages leading from Manchuria and Vladivostok have many tunnels and bridges. I see here a unique use for the atomic bomb-to strike a blocking blow. ${ }^{36}$

As Bruce Cumings notes, this was 'roll-back with a vengeance' and a very early suggestion of deliberate tactical employment of atomic weapons, a notion that frequently recurred throughout the conflict. ${ }^{37}$

General Bolte—one of the more atomically aggressive members of the Army staffbelieved that, concurrent with reporting MacArthur's views, this was the appropriate time to get Truman's approval for use of the bomb. ${ }^{38}$ Bolte also suggested that they should, at some point in the future, discuss the matter more fully with MacArthur. ${ }^{39}$ Upon his return, Collins could not recollect ever receiving the July 13 memo and instructed that any mention of supposed atomic discussions with MacArthur be stricken from the record. ${ }^{40}$ MacArthur and Bolte were thus joined in advocating a concept in Korea at odds with the evolving theory of limited war. MacArthur in particular preferred grandiose dreams of re-unifying Korea under the banner of the UN, with himself as conquering commander. It was an attitude that had dramatic and dire consequences in the coming months.

\section{Belief in Control From Moscow}

A belief that the USSR controlled the communist forces in Korea permeated US thinking. American planners saw communism as a monolithic entity controlled directly by the Kremlin. Even cool-headed decision makers such as Acheson and Nitze believed that the United States was dealing with a merciless enemy bent on destruction of the American way of life and domination of the entire world. ${ }^{41}$ Confusion about whether Korea presaged an expanded global war of conquest by the Soviet Union was endemic throughout political and

36 Memorandum for General Gruenther from General Bolte, 'Use of the Atomic Bomb in Korea', OPS 091 Korea TS, July 24, 1950, RG319, NARA, p.1.

37 Bruce Cumings, Child of Conflict: The Korean-American Relationship, 1943-1953, Seattle, 1983, p.53

38 Gruenther from Bolte, 'Use of the Atomic Bomb in Korea', p.1.

39 Ibid, p.2.

40 Memorandum for Assistant Chief of Staff, G-3 (Bolte), from J. E. Moore, Secretary of the General Staff, 'Use of the Atom Bomb on Korea', 21 August, 1950, RG319, NARA. 'G-3' was military shorthand for the Assistant Chief of Staff responsible for operations and plans.

41 Marc Trachtenberg, 'A "Wasting Asset": American Nuclear Strategy and the Shifting Nuclear Balance, 1949-1954', International Security, Vol.13, No.3 (Winter, 1988-1989), p.12. 
military circles. ${ }^{42}$

The JCS was concerned about the over-commitment of resources in minor theatres such as Korea when they could be better deployed for any coming wider conflict in Europe. ${ }^{43}$ General Bradley questioned the need to commit military forces in an area that was of slight strategic importance and was, according to the US view, in an area chosen by the USSR as a point of conflict. ${ }^{44}$

On July 29 NSC-73/1 presented several options for the future. NSC-73/1 argued that the United States was in no way prepared to fight a global war due to inadequacies in position and manpower. ${ }^{45}$ On the other hand, it suggested that while the USSR could easily conquer Western Europe by conventional military force, the Soviets could not prevent a nuclear attack by the United States nor immediately cripple US industrial potential. ${ }^{46}$ However, the levelheaded suggestions of NSC-73/1 did not gain traction: the report's findings were not presented to the American public and they and many politicians continued to believe that the USSR could devastate the USA with an atomic strike.

\section{A Policy for the Future}

In the days prior to the September 15 Inchon landings, the NSC submitted a report giving a detailed outline of what future US policy in Korea should be. NSC-81 laid out in bald terms that the unification of the peninsula was politically desirable. The objective for the UN was to 'bring about the complete independence and unity of Korea' as long as this objective could be achieved without precipitating a general war with either the USSR or PRC. ${ }^{47}$ NSC-81 was approved by President Truman on September 11 and by the end of the month official leave was granted for MacArthur to take his troops across the 38th parallel.

The stipulations of NSC-81 made it clear that the US still hoped for a limited conflict in Korea. Yet signals from Beijing warned that all would not be well if MacArthur continued

42 CIA Intelligence Memorandum 302 'Consequences of the Korean Incident', July 8, 1950, CIA FOIA, accessed on June 9, 2009.

43 NSC-76, 'Memorandum by the Joint Chiefs of Staff to the Secretary of Defence (Johnson)', July 10, 1950, FRUS 1950, Vol.7, p.346.

44 Ibid.

45 NSC-73/1, 'The Position and Actions of the United States With Respect to Possible Further Soviet Moves in Light of the Korean Situation', July 29, 1950, DNSA, pp.1-2.

46 Ibid, p.3.

47 NSC-81 'United States Courses of Action With Respect to Korea', September 1, 1950, DNSA, p.2 
his post-Inchon advance. On September 25, Indian ambassador to China, K. M. Panikkar, met with General Nieh, Chinese Chief of Staff. Nieh informed the ambassador that China did not intend to ignore the American advance to their border. ${ }^{48}$ Panikkar attempted to impress upon the General the destructive capabilities of the American war machine, but Nieh was unmoved:

They may drop atom bombs on us. What then? They may kill a few million people. Without sacrifice, a nation's independence cannot be upheld...After all, China lives on the farms. What can atom bombs do there? ${ }^{49}$

On October 2-3, Panikkar met with Zhou Enlai, the Chinese Premier. Zhou bluntly backed up Nieh, adding that whilst the Chinese people earnestly wished for a peaceful settlement to the Korean conflict, if UN forces crossed the $38^{\text {th }}$ parallel China would have no option but to intervene..$^{50}$

When news of the Panikkar discussions reached Washington, officials were unimpressed. Acheson did not regard the communications as authoritative and officials such as Nitze distrusted information from the Indian ambassador. ${ }^{51}$ Thus, the administration chose to act in a cavalier fashion and broadly ignore signals that China was preparing to intervene. Allen Whiting suggested that the Chinese threats did not receive the attention they deserved due to issues inherent in the means by which they were communicated, the means of implementing the threat (both of which related to the mistrust of Panikkar), and the perception that a decision by Chinese leaders to go to war would be irrational in light of their exhausting experiences in the Civil War. ${ }^{52}$

\section{Worries About Chinese Involvement}

Potential Chinese involvement, despite the setting aside of Panikkar's warnings, still played on the minds of officials after the first, low-level Communist People's Volunteer Army (CPVA) incursions across the Yalu River towards the end of October. Inevitably, the question of whether or not to use the atomic bomb surfaced. On November 4, questions were raised about the tactical employment of the bomb in a conversation between Nitze and Brigadier

48 K. M. Panikkar, In Two Chinas, London, 1955, p.108.

49 Ibid.

50 Ibid, p.110.

51 Dean Acheson, The Korean War, New York, 1971, p.55; Casey, Selling the Korean War, p.99; Nitze, From Hiroshima to Glasnost, p.108.

52 Allen S. Whiting, China Crosses The Yalu: The Decision to Enter the Korean War, Stanford, 1960, pp.109-110. 
General Herbert B. Loper, an army officer involved in atomic matters. Both men concluded that tactical use of the weapon could be effective but that it would not be 'militarily decisive'. ${ }^{53}$ The short memo recording this meeting highlighted several points that would echo throughout the conflict: questions of subservience to the UN; the moral position of the US in the aftermath of nuclear attack; and the threat of a broader war with the PRC and USSR. ${ }^{54}$ Three days later, the PPS opined that the Chinese might genuinely be anticipating and accepting the imminence of World War III but the US should not take any action that gave 'international renegades' the excuse to expand the conflict on a global scale. ${ }^{55}$ The PPS concluded that the PRC's truculent propaganda over the A-bomb was a bluff to force an advantageous, non-military solution to the Korean War. ${ }^{56}$

However, senior figures within the PRC had already concluded, weeks earlier, that the US would never resort to using nuclear weapons either in Korea or against China proper and constructed their plans accordingly. ${ }^{57}$ The rural nature of China and the sheer size of the population, as outlined by General Nieh, meant that US atomic capability, while worrisome, would therefore not militate against Chinese intervention on behalf of the DPRK ${ }^{58}$

While the State Department communications of early November 1950 considered the use of the bomb, they raised serious questions about on whose authority it could be employed. It was frequently mentioned that atomic weapons could only be used as part of a UNmandated effort. O. Edmund Clubb, Director of the Office of Chinese Affairs, writing on November 7, feared that unilateral use of the bomb would split the UN and bring the USSR into the conflict. ${ }^{59}$ Clubb offered an opinion that would broadly be expected from an officer of the State Department: 'Military strategy must follow that political strategy which, it must be emphasized, contemplates maintenance of the united UN front, for the safety of each and

53 Memorandum by the Director of the Policy Planning Staff (Nitze), November 4, 1950, FRUS 1950, Vol.7, p.1041-1042.

54 Ibid.

55 Draft Memorandum by Mr. John P. Davies of the Policy Planning Staff, November 7, 1950, FRUS 1950, Vol.7, p.1079, 1082

56 Ibid, p.1078.

57 Sergei N. Goncharov, John W. Lewis, and Xue Litai, Uncertain Partners: Stalin, Mao, and the Korean War, Stanford, 1993, pp.164-167.

58 Stueck, Rethinking the Korean War, p.110.

59 Memorandum by the Director of the Office of Chinese Affairs (Clubb) to the Assistant Secretary of State for Far Eastern Affairs (Rusk), November 7, 1950, FRUS 1950, Vol.7, pp.1087-1093. 
every one of those States which have resisted aggression in Korea. ${ }^{160}$

The Chinese, meanwhile, continued to intimate that the UN should limit the war in Korea. On November 6 the media noted that Chinese state radio had broadcast a statement warning the US not to use the atomic bomb because American cities 'offered a choice target for retaliation. ${ }^{61}$ As the PRC lacked any form of strategic air power the threat was either deliberate bluster or an attempt to underscore the alliance between the PRC and the militarily powerful USSR. Two weeks later the Vice-Premier of the PRC, speaking at the Second World Peace Congress in Warsaw, amplified the demands of the Stockholm Peace Petition and castigated MacArthur as 'the principal instigator in expanding the Korea war [sic] into a world war. $^{162}$

One day after the memo from Clubb, another report landed on the desk of Dean Rusk, underlining the potential damage that use of the A-bomb could cause to US prestige and moral standing. Baldly titled 'Use of the Atomic Bomb in China', it brought together several threads regarding nuclear weapons. Reiterating arguments that were made after the outbreak of war, the memo suggested that there were few targets worthy of an A-bomb in China and raised the spectre of Hiroshima by positing a 'damaging reaction' if bombs were used against cities: although the destruction achieved by nuclear weapons might well be identical to that achieved by conventional bombing, the world reaction would be markedly different. $^{63}$ The atomic bomb had 'the status of a peculiar monster conceived by American cunning and its use by us, in whatever situation, would be exploited to our serious detriment. ${ }^{164}$ Unilateral use of the weapon outside of the sanctions of the UN would likely receive worldwide denunciation and feed Soviet propaganda that the US was hell-bent on igniting another global conflict.

Furthermore, the memo raised the troubling issue of race. Dropping bombs on the Koreans or Chinese would cause a wave of revulsion to sweep round Asia and further strengthen the opinion that atomic weapons were reserved by white powers for use against

60 Ibid, p.1091.

61 NA, 'Chinese Warn US On Use of A-Bomb', Washington Post, November 6, 1950, p.3.

62 Edward A. Morrow, 'Peiping Aide Adds To Blows At US', New York Times, November 19, 1950, p.7.

63 Memorandum by the Planning Adviser, Bureau of Far Eastern Affairs (Emmerson) to the Assistant Secretary of State for Far Eastern Affairs (Rusk), November 8, 1950, FRUS 1950, Vol.7, pp.1098-1099

64 Ibid, p.1099. 
Asiatics. ${ }^{65}$ The State Department concluded that any military advantage that might be gained by the use of nuclear weapons would be dwarfed by the massive damage done to the united front supporting the ROK, the relationship between the US and Asian states, and the real potential to ignite an expanded war with China. ${ }^{66}$ And, as Tannenwald noted, the analyses offered by the State Department clearly argued that the atomic bomb should not be considered alongside other, conventional weapons and hence any decision on its use in Korea must meet a far sterner test. ${ }^{67}$ Here, this thesis agrees with the argument put forward by Tannenwald.

Military thinkers also agitated for a revision of the existing position. On November 20, General Collins advised the other Joint Chiefs to prepare contingency studies on the use of atomic weapons in Korea. ${ }^{68}$ The JCS, and Collins in particular, envisaged a chain of events whereby massive Chinese air attacks on UN forces would force a complete withdrawal from the peninsula. Under these circumstances, there was no alternative but to resort to the Abomb. $^{69}$

The PPS — instrumental in formulating the State Department position—considered the possibility of an expanded war not only with China, but also with the USSR. The Kremlin was positioned as considering war inevitable. This characterisation of the Soviet acceptance of risk was qualified by an outline of the desire on the part of the USSR to avoid responsibility for aggressive action and to operate in a manner that would encourage satellites and allies to carry out the work of confronting US power. ${ }^{70}$ In the face of this risk, the PPS recommended that the programme of increased military spending and preparedness outlined in NSC-68 (ratified by Truman in September) should be expanded and accelerated to face the coming confrontation with the Soviets. ${ }^{71}$

At the same time, the NSC was considering a list of questions related to the tactical and strategic use of nuclear weapons. Rather than being a statement of policy, this short document laid out what factors should be taken in to account if the US launched an atomic

65 Ibid, p.1100.

66 Ibid.

67 Tannenwald, The Nuclear Taboo, p.120.

68 Foot, The Wrong War, p.116.

69 Crane, American Airpower Strategy, pp.56-57.

70 Memorandum by Mr. John P. Davies of the Policy Planning Staff, November 17, 1950, FRUS 1950, Vol.7, p.1179-1180.

71 Ibid, p.1182. 
attack. Questions such as 'Could it be militarily decisive?' and 'What would be the effect of its use on public opinion in the United States, in allied countries, in Asia?' condensed the ongoing debate and starkly delineated the key issues. ${ }^{72}$ All of these issues, however, were thrown into sharp relief when the CPVA flooded across the Yalu River on November 28.

This early period of the war demonstrates that individuals, rather than institutions exercised the greatest influence over whether or not to use the A-bomb. For example, although the PPS was one of the key actors within government at this time, it was individuals such as Clubb and Nitze who were the main architects of policy. At the opposite end of the spectrum, generals such as MacArthur and Bolte were pushing for use. The position of MacArthur is especially notable, as his individual power over the US position became even more significant and contentious as the war progressed.

It is also clear that apprehension regarding the imminence of a major global war, and the realisation that using the US's ultimate weapon—-the atomic bomb—could provoke exactly that kind of war, served to promote restraint. There is, however, little attention paid in the scholarship to the immense mental stress that that conundrum-a powerful weapon, but so powerful it was unusable-created for Truman. That stress expressed itself in angry outbursts—-public and private—on a number of occasions throughout the war. But this thesis also argues that it was out of that stress and turmoil that Truman gained a mature understanding of the non-usability of the atomic bomb.

\section{OUTSIDERS}

\section{Congressional Opinion}

On Capitol Hill, although lawmakers aligned themselves in to a variety of camps, depending on their views on the atomic bomb, the most vocal were those calling for swift action against the 'aggressors'. Many believed that the only way to counter what was happening in Asia was to strike against the sources of control: the communist leadership in

72 Carlton Savage, 'Questions to be Considered Regarding Possible US Use of the Atomic Bomb to Counter Chinese Communist Aggression in Korea', November 8, 1950, RG59, NARA. 
Peking and Moscow.

Conspicuous by his absence in the earliest days of the conflict was Joe McCarthy. The national unity which came with the stand against communist aggression was disadvantageous to the junior Senator from Wisconsin, who worked best in an atmosphere of mistrust and recrimination. ${ }^{73}$ But it was not long before the arch anti-communist made his feelings known. On July 6 he stood on familiar territory, viciously attacking the 'communists, fellow travellers, and dupes in our State Department. ${ }^{.74}$ It became clear that feelings of national unity did not hold back the most outspoken critics of the administration for long.

July 12 saw a flurry of Congressional pronouncements on the Korean issue. Lloyd M. Bentsen proposed atomic attack on North Korean cities. ${ }^{75}$ Using terminology that became common in pro-bomb arguments, he argued that, without the authority to use the A-bomb, the United States was fighting with one hand tied behind its back. ${ }^{76}$ He concluded his brief speech with the chilling warning that 'the atomic bomb awaits those who would violate the peace of free men. ${ }^{177}$ Owen Brewster went further than Bentsen, and urged that MacArthur should have full discretion to use the atomic bomb as a deterrent to other communist nations. ${ }^{78}$ He blamed the Democrats for getting the United States involved in two world wars and potentially involving them in one more. ${ }^{79}$ This quasi-isolationist position came to the fore with the increased involvement of Senator Robert A. Taft (R-OH) in late 1950 and into 1951. The position and influence of Taft, and his constituency within the Republican Party, are examined in Chapter Three.

Other influential politicians cast the Korean situation in a global context. Senator Alexander Wiley (R-WI) agreed that Korea was part of an overarching plot controlled by Moscow. Furthermore, he advised that the United States should not be caught asleep, as he claimed it had been in the lead up to World War II. ${ }^{80}$ Wiley also invoked the atomic bomb by warning of a potential attack upon the United States and the creation of an 'entirely new

73 David M. Oshinsky, A Conspiracy So Immense: The World of Joe McCartby, New York, 1983, p.167.

74 Ronald J. Caridi, The Korean War and American Politics: The Republican Party as a Case Study, Philadelphia, 1968, p.41.

75 Lloyd M. Bentsen, July 12, 1950, Congressional Record-House (bereafter CRH), 81st Congress, 2nd session (hereafter 81/2), Vol.96, Pt.8, p.10022.

76 Ibid.

77 Ibid.

78 Robert C. Albright, "Hill' Speeches Urge Warlike Measures', Washington Post, July 13, 1950, p.2.

79 Ferdinand Kuhn, 'Truman Cleared Air for Befogged Western World', Washington Post, July 2, 1950, p.B1.

80 Alexander Wiley, July 12, 1950, Congressional Record-Senate (hereafter CRS), 81/2, Vol.96, Pt.8, pp.9994-9997. 
world climate' engendered by the bomb's development. ${ }^{81}$ His speech-implying that the US must be prepared to use the bomb in retaliation—connected the issues of national security, the war in Korea, and the atomic bomb in one deft move by harking back to Pearl Harbor and doubts about the security of the continental United States. Wiley's speech was supported by John M. Vorys (R-OH) who suggested in private comments to State Department officials that war with the Soviet Union was inevitable and hence US planning should focus on victory through nuclear and air superiority. ${ }^{82}$

Brien McMahon_Chairman of the JCAE—forcefully challenged the panicked reaction of his fellow politicians. ${ }^{83}$ In a question and answer session on the NBC 'America's Press Conference of the Air' television programme on July 17, when asked by one interviewer what he thought of calls by Bentsen, Brewster and Wiley to use the atomic bomb in Korea, McMahon answered 'I do not think the suggestion is a good one. I believe that the North Korean war is of such a character as to rule out use of the atomic bomb. ${ }^{184}$

Veering back towards reasons why Korea was not a good target for the A-bomb and the possibility of dropping the weapon on Pyongyang, the Senator touched on what would become one of the main arguments against the use of atomic weapons. McMahon commented that:

as I see the Korean situation you have troops widely dispersed. The atom bomb is primarily a weapon to strike at the sources of power or at troops that would be so massed as to furnish a target. ${ }^{85}$

Power was not concentrated in North Korea according to McMahon, but stemmed from elsewhere, hence in strictly military terms the atomic bomb was manifestly unsuited for the Korean battlefield. ${ }^{86}$ McMahon's interview framed the atomic issue as one of material, military concerns rather than as a moral question. Thus, he was not advocating restraint because of any ethical concerns about the use of the weapon but because of a lack of suitable targets and a belief that the centres of power were located in Moscow and Beijing, not in Pyongyang.

81 Ibid, pp.9996-9997.

82 Casey, Selling the Korean War, pp.71-72.

83 McMahon was the sponsor of the 1946 bill, subsequently known as the McMahon Act, that set up the AEC and forbade the US government from sharing atomic technology with other nations. The Act would only be repealed in 1958.

84 Transcript of NBC 'America's Press Conference of the Air' interview with Brien McMahon, July 17, 1950, CRS, 81/2, Vol.96, Pt.8, p.10371.

85 Ibid.

86 Ibid. 
McMahon's long held position as a vocal advocate for the expansion of nuclear forces to defend America and his many years immersed in the minutiae of atomic issues made his opinion an authoritative one. ${ }^{87}$ McMahon's position on non-use was based upon a background of careful consideration of nuclear issues and an acknowledgement that, in certain circumstances, the bomb may have to be used.

In light of this rebuttal from one of the foremost authorities on atomic matters, Brewster issued a hasty clarification of his position. As an amateur in atomic affairs, he suggested, he had refrained from offering an opinion on the wisdom of actually using the bomb in Korea. ${ }^{88}$ Brewster claimed that his statements had been misinterpreted and that:

inasmuch as we have spent billions in developing the atom bomb, and inasmuch as at the present time our boys are dying because of an inadequate defence, the President should have authority in his discretion to direct that the atom bomb be used. ${ }^{89}$

Thus, at least one bomb enthusiast was forced on to the back foot, if only for the time being.

There was a burst of media activity surrounding these early speeches coming from Capitol Hill. The Washington Post and the New York Times gave wide-ranging coverage to the statements made by both sides of the debate with the Post characterising the speeches by Bentsen and Brewster as reflecting the mounting alarm and tension about the war that was building inside Congress. ${ }^{90}$

It is important, however, not to overstate the influence or, indeed, the motivations of those calling for atomic attack. They were a minority: the vast majority of Congressmen and Senators chose not to comment on the issue. The upcoming Congressional election was in the minds of many of the most vocal individuals on Capitol Hill. All Congressmen were due for re-election, as were a proportion of Senators. Many were doubtless thinking of their position as much as they were thinking of the fate of American soldiers in Korea. Republicans in particular used the war and the difficulties of the Truman administration as a golden opportunity to engage in a partisan political offensive. ${ }^{91}$ As Ronald J. Caridi noted:

One of the major problems that Republicans faced when calling for greater

87 Condit, History of the Office of the Secretary of Defense, p.84.

88 Owen Brewster, July 17, 1950, CRS, 81/2, Vol.96, Pt.8, p.10373.

89 Ibid.

90 Robert C. Albright, "Hill' Speeches Urge Warlike Measures', Washington Post, July 13, 1950, p.2.

91 Casey, 'White House Publicity Operations', p.696. 
vigour in the prosecution of the war was their own realisation that stronger action increased the possibility of Russia's intervention in the conflict. ${ }^{92}$

The situation Republicans found themselves in was, in many ways, just as conflicted as that experienced by Truman. The atom bomb represented strength and determination in the face of communism, yet the isolationist tendency within the Grand Old Party (GOP) created tension between potential use of the weapon (leading to intractable involvement in foreign affairs) and non-use of the weapon (which could be positioned as being soft on communism). The minority who called for use of the bomb either lacked a substantive understanding of world affairs or sought to attack the administration on any issue. There is an irony in the fact that the Democrats — who had created containment and chose, without hesitation, to meet 'the Reds' head-on in Korea_were lambasted throughout the war as being soft on communism.

\section{Scientific Opinion}

Little has been said in the existing scholarship on non-use of the position of the scientific community. As a prominent, publicly visible, and politically influential intellectual elite, their position rewards study.

Eugene Rabinowitch, an eminent biophysicist and participant in the Manhattan Project, printed a lengthy editorial on the subject of nuclear weapons in the July issue of The Bulletin of the Atomic Scientists. Rabinowitch placed Korea in its geopolitical context and argued that strategic bombardment with atomic weapons in any of the potential flashpoints around the globe, such as Yugoslavia, Greece, or Korea, was not an appropriate response. ${ }^{93}$ He further stated that all over the world:

we would be facing the question of how to protect a country from subjugation, or liberate a country already subjugated by an expansionist, totalitarian political system-without decimating its people and destroying their wealth, their homes and their beloved ancient cities and monuments. ${ }^{94}$

Thus, the use of the A-bomb in any of these limited war scenarios, including the ongoing crisis in Korea, was moot. The United States could not achieve its political aims of negating

92 Caridi, The Korean War and American Politics, p.75.

93 Eugene Rabinowitch, 'Atomic Weapons and the Korean War', The Bulletin of the Atomic Scientists, Vol.6, No. 7 (July, 1950), p.194.

94 Ibid. 
the threat posed by the USSR and halting the spread of communism if it decided to utilise the atomic arsenal. Such an action would alienate allies and drive neutrals into the Soviet embrace.

Rabinowitch's editorial was reported in the daily and weekly press. On July 25 the New York Times and the Washington Post both offered summaries of Rabinowitchs' comments under the titles 'Atom Bomb Held Useless For Warfare in Korea' and 'A-Bomb Use in Korea 'Obviously Absurd". ${ }^{95}$ The Times additionally noted that the hydrogen bomb-the development of which had recently been made public_-would not have helped in Korea. ${ }^{96}$

But the press itself stole a march on the Bulletin on July 17 . Widely respected military editor of the New York Times Hanson W. Baldwin wrote an op-ed piece that presaged much of what Rabinowitch was to articulate. Baldwin opened his commentary by slyly attacking an unnamed 'one or two members of Congress more noted for their vehemence than their sagacity. ${ }^{197} \mathrm{He}$ characterised those calling for the use of the bomb as 'the voice of doom' and posited that the whole aim of the war should be to avoid using atomic weapons. ${ }^{98}$ Rabinowitch and Baldwin thus both framed their arguments in terms of the moral issues, rather than the predominantly materialist approach adopted by the likes of McMahon.

Their stances were echoed in an open letter to the New York Times on 6 August, from the Brookhaven Chapter of the Federation of American Scientists (FAS). The chapter outlined its opposition to deploying the bomb in Korea. Any consideration of atomic weapons, it argued, must involve not simply an analysis of the military consequences, but also of the moral and political consequences. ${ }^{99}$ Here the scientists came into conjunction with evolving thinking in Washington. The A-bomb was no longer just a weapon, it was a concept around which politics, ethics, and war coalesced. It was characterised as a drastic, inflexible weapon which would not only bring death to countless civilians but also condemn future generations through the effects of radiation. ${ }^{100}$ The bomb could be decisive, but not in the way that some military planners hoped. Echoing Rabinowitch, they concluded that the A-Bomb would force wavering countries, especially those in Asia, into the Soviet orbit and would, they

95 NA, 'Atom Bomb Held Useless For Warfare in Korea', New York Times, July 25, 1950, p.10.; NA, 'A-Bomb Use in Korea 'Obviously Absurd", Washington Post, July 25, 1950, p.3.

96 NA, 'Atom Bomb Held Useless For Warfare in Korea', New York Times, July 25, 1950, p.10.

97 Hanson W. Baldwin, 'Atomic Bomb Is Not The Weapon', New York Times, July 17, 1950, p.4.

98 Ibid.

99 FAS Brookhaven Chapter, 'Atom Warfare Opposed', Letter, New York Times, August 6th, 1950, p.E8.

100 Ibid. 
stated, be morally wrong and politically foolish. ${ }^{101}$

Given the scientific community's vocal opposition to the A-bomb, it is curious that their opinion has largely been ignored by historians looking at the issue of non-use. Botti, Calingaert, Dingman and Tannenwald made little or no mention of the scientists in their studies of the Korean conflict. However, Rabinowitch's article is illustrative of the important part scientific opinion played in the A-bomb debate. His views were widely disseminated by the media and, while they may not have exerted a direct influence on policy-making, certainly helped to mould public opinion. Moreover, the scientist's position assisted in giving intellectual authority to key media figures such as Hanson Baldwin. We therefore cannot ignore the voices of the scientists when studying non-use of the A-bomb.

\section{Public Opinion}

As the scientific community pronounced on the atomic issue, the print media quickly made the connection between the fighting in Korea and the A-bomb. Time Magazine, for example, had always been at the forefront of backing a strong American presence in Asia. Under the rule of founder, managing editor, staunch anti-communist, and Asia enthusiast Henry R. Luce, Time offered readers pages filled with patriotism, grandeur and 'America's God-ordained call to defend the far-flung ramparts of freedom. ${ }^{102}$ On July 10, Time questioned whether World War III and atomic apocalypse had arrived. It went on to decry the communist intention to destroy all that was good in the world and equally castigated the American government for its failures in Asia. ${ }^{103}$

Newspapers found themselves on the receiving end of letters supporting and opposing the use of the atomic bomb in Korea. One correspondent thought that the USSR would supply the DPRK with A-bombs, therefore dropping them pre-emptively was perfectly acceptable. ${ }^{104}$ Another letter-writer, based upon his experience with communists in post-war Italy, took a similar view and suggested launching attacks on the 'fanatical materialists' in

\footnotetext{
101 Ibid.

102 Robert E. Herzstein, Henry R. Luce, Time, and the American Crusade in Asia, Cambridge, 2005, p.112.

103 NA, 'In the Cause of Peace', Time Magazine, July 10, 1950, Time Magazine on-line archive at http://www.time.com/time/magazine/article/0,9171,805446,00.html, accessed on June 8, 2009. 104 Alfred A. Mays, Letter, Washington Post, July 4, 1950, p.8.
} 
Moscow. ${ }^{105}$ William Esslinger of New York took a less violent line and argued that there could be no justifiable reason for using the A-bomb in Korea. ${ }^{106}$ A reader of the New York Times brought up the matter of race, something that came to the fore as the war progressed, suggesting that using the bomb would only alienate Asia. ${ }^{107}$

But, influenced by pronouncements in the press, the general public feared an expanded war. In a poll conducted between July 30 and August 4, fifty-seven percent of respondents thought that the United States was fighting the opening battles of World War III; only twenty-eight percent of those polled felt that the Korea would stop short of another world war. ${ }^{108}$ And public fear did not translate into a willingness to see the A-bomb used in anger. In another poll, conducted between August 20 and 25, only twenty-eight percent of respondents believed that the United States should use the A-bomb in Korea. ${ }^{109}$ The general public obviously did not feel that using the bomb in Korea itself was a worthwhile use of the weapon because, in the same poll, seventy-seven percent of people believed that the United States should use the atomic bomb if it became involved in another world war. ${ }^{110}$

While it is difficult to extrapolate the opinions of a nation from a handful of polls, John Mueller has observed that in ninety-five percent of cases the results of an opinion poll will be within a few percentage points of the 'real' value. ${ }^{111}$ This brief sample of three polls, all carried out in a two month period, shows that on the whole, the American public supported the use of the atomic bomb, but only in the situation of an outright world war. 'World war' in this case was synonymous with 'war with the Soviet Union'. Korea, the public felt, simply did not justify the use of the A-bomb, even though many believed they were seeing the opening days of a larger conflagration.

Despite the polling evidence, an important question remains: would the American public retreat from use of the A-bomb under all circumstances, even during the posited World War III scenario? The opinions given on using the bomb in circumstances of general war are far from as robust as the opinions given for non-use in Korea. The Korean questions dealt

105 O. P. Lee, 'Destroying Communism', Letter, Washington Post, July 18, 1950, p.12.

106 William Esslinger, 'Bomb in Korea', Letter, Washington Post, August 9, 150, p.12.

107 Hedley V. Cooke, 'Korea and Our Asia Policy', Letter, New York Times, July 13, 1950, p.24.

108 George H. Gallup, The Gallup Poll: Public Opinion 1935-1971, Vol.2: 1949-1958, New York, N.Y., 1972, p.933.

109 Ibid, p.938.

110 Ibid.

111 Mueller, War, Presidents and Public Opinion, p.3. 
with a concrete circumstance, whereas the World War III question dealt with a hypothetical situation. It is well nigh impossible to extrapolate with any degree of certainty whether or not the American public would have backed the use of the atomic bomb in an expanded war. The polling evidence suggests that they were amenable to use in far-off, abstract circumstances but when it came to a decision on using the weapon in a conflict that was actually taking place, the majority were against use.

As with key decision-makers, the public position on use or non-use was never an open and shut case. In these early days, the American public were not as belligerent as might have been thought and leaned towards non-use in Korea. Subsequent chapters will examine what changes, if any, took place in the position of the American public as a whole. Would they become more belligerent as the war dragged on or would the overall desire not to use the bomb in an immediate, concrete circumstance remain the norm?

In all of the 'outsiders' examined, it is evident that there are contradictions and paradoxes. Both sides of the debate were vocal, and there was little middle ground. While the scientific community—as shown by the examples of the Rabinowitch and the FAS-were generally of one mind, Congress and the general public were of a more fractured, conflicted state. Few other commentators have explored this under-examined area of debate on use/non-use and, as will be demonstrated in subsequent chapters, throughout the course of the war, informative threads which enhance understanding of the evolution of non-use, may be teased out of the views of outsiders.

\section{CONCLUDING REMARKS}

One surprise in terms of public commentary by the administration on the potential use of atomic weapons in Korea is the manifest lack of substantive comments from figures such as Truman and Acheson. More junior politicians, media pundits, and the scientific community were far more vocal in expressing opinions than the upper echelons of government. There was, however, in the first few weeks of war, serious planning taking place for the potential use of the bomb. The USAF plans ordered by Truman on the very first day, the consideration given to the moral aspect of the bomb in high-level analyses and the 
deployment of atomic-capable B-29s to the United Kingdom and Guam all demonstrate that there was consideration of use. Dingman suggested that the June-July 1950 period represented a situation where the administration and its military advisors maintained a belief that even without 'explicit statements of intent', the deployment of nuclear capable bombers would still serve as a deterrent. ${ }^{112}$ But the evidence demonstrates that it is not clear that the deployments had any influence at all on the USSR or PRC. Certainly, they had no influence whatsoever on the DPRK forces rampaging down the peninsula. This assists in shaping the ongoing story of non-use throughout the war: the senior figures, political and military, who had genuine control over nuclear weapons were less convinced of the bomb's utility than has been previously suggested.

During this first phase of the war we also see the development of the argument over the morality of the bomb. Many insiders, particularly those within the State Department and specifically the PPS, demonstrated an awareness of the moral factor. Both Nitze and his subordinate Carlton Savage are on record as focussing on this factor. For Nitze, the concern was over the position of the United States after atomic weapons use. For Savage, the emphasis was on using the bomb in a humane way: striking military, rather than civilian, targets. Moreover, notable media figures were vocal in their attention to the moral dimension. Eugene Rabinowitch and Hanson Baldwin both trod the same ground, expressing deep-seated moral concerns over the atomic issue. For men such as them, morals overrode materialistic concerns about targets and stockpiles. But it is informative to look at the case of Brien McMahon, who, while an advocate of a strong atomic defence policy, was one of the staunchest defenders of the administration and a trenchant critic of those calling for A-bomb use. McMahon framed his arguments in very materialist terms when he highlighted, for example, a lack of targets and the limited nuclear stockpile.

Overall, a genuine fear existed of World War III starting over Korea. These fears were stoked by media reporting of the shrill cries for the immediate use of atomic weapons emanating from Congress. Elements of the US government were certainly complicit in fanning the fires of war fear, with agencies such as the CIA suggesting that Stalin might be

112 Dingman, 'Atomic Diplomacy', p.65. 
close to provoking a general war. ${ }^{113}$ The fear of open conflict with the Soviet Union was, as Richard Betts points out, a reason why the military was less than enthusiastic about using some of their precious nuclear stockpile in Korea. ${ }^{114}$

Fear of an atomic war in Korea, perhaps expanding to engulf the world, was not something that subsided. It appeared once more, even more ominously than before, when, on November 28, 1950, China finally committed itself fully to Korea. If the five months from June to late November of 1950 can be characterised as one of panic and blind fumbling with a new form of war in a hitherto unexpected situation, then the same can be said for debate over atomic weapons during the period. Their very existence made them open for discussion, but their use was never considered beyond general planning and speculation. In the end, they exerted very little influence on the conduct of the war at this stage. The consideration of nuclear attack in, and beyond, Korea became far more serious from November 28 onwards. 


\section{Chapter 2: 'Always Under Consideration'}

On November 28, 1950, Douglas MacArthur realised that his push towards the Yalu River had suddenly transformed into a full-scale rout and the Korean War had changed utterly. Despite the misgivings of General Walker, his senior commander on the ground, MacArthur had ordered his forces to forge ahead into the northernmost reaches of the DPRK. And now the war had drawn in the PRC. In the words of the Supreme Commander, the administration and the military were now facing 'an entirely new war.'

Prior to the large-scale Chinese intervention, and despite the worst fears of the US government, military, and general public, the Korean War had remained limited in scope. While a multi-national force fought on one side, the 'enemy' remained the DPRK, albeit supplied with weapons, equipment, and 'advisors' by China and the USSR. UN successes in the wake of the Inchon landings reversed the war's course and drove DPRK troops back towards the $38^{\text {th }}$ parallel. MacArthur, going beyond the war aims outlined over the previous months of fighting, was determined to drive the communists out of Korea. The fateful decision to move his armies into the far north, wilful ignorance of warnings from the PRC, and the final commitment of the CPVA ushered in an even more fraught period in the conflict.

The involvement of the Chinese led to the first open admission, from Truman himself, that use of atomic weapons was under consideration. Once again, however, US leaders refrained from deploying their ultimate weapon. This chapter investigates what factors dictated this course of action during this crucial phase of the conflict. Particular focus is placed on the importance of the fear of global war to non-use: a factor that Tannenwald played down but which was instrumental in staying the hand of the United States. ${ }^{3}$ This chapter also critiques Dingman's broadly institutionalist and materialist explanation of nonuse. An examination of the critical days surrounding Truman's 'consideration' statement, when global fear of nuclear confrontation reached previously unseen heights strongly suggests a

1 Acheson, The Korean War, p.73.

2 The Commander in Chief, Far East (MacArthur) to the Joint Chiefs of Staff, November 28, 1950, FRUS 1950, Vol.7, p.1237

3 Tannenwald, The Nuclear Taboo, p.129. 
broader perspective is called for. In sum, as one of the key phases in the development of the Truman administration's 'nuclear education', it is vital that the early days of December 1950 be given a thorough examination.

\section{The November 30 Statement}

The skirmishing between CPVA and UN forces in October and November was but a prelude to the main action. The massive commitment of Chinese forces to the fray brought chaos to the UN lines: a victorious march towards the Yalu River was turned into ignominious retreat. MacArthur, in a series of increasingly panicked messages from Tokyo, was convinced that the aim of Chinese intervention was the utter destruction of UN forces in Korea. ${ }^{4}$ Washington was concerned that the allied armies might be driven into the sea by the assault, handing victory to the communists. If, MacArthur suggested, he was allowed to conduct a naval blockade, undertake aerial bombardment of China, bring in Nationalist Chinese forces from Taiwan and possibly use the A-bomb, then UN forces could continue to hold on to their positions. $^{5}$

In Washington, Truman was about to walk into the war's most notable press conference. Harassed by an excited press pack, he reacted to questions in typically brusque fashion and set off a fire-storm of controversy that spread around the globe. Truman lambasted the Chinese by stating that 'this new act of aggression in Korea is only a part of a worldwide pattern of danger to all the free nations of the world', placing Korea in the context of a potential expansion of hostilities. ${ }^{6}$ After completing his prepared remarks, Truman was quizzed by journalists on the military situation in Korea:

Truman: We will take whatever steps are necessary to meet the military situation, just as we always have.

Journalist: Will that include the atomic bomb?

Truman: That includes every weapon that we have.

Journalist: Mr. President, you said "every weapon that we have." Does that mean that there is active consideration of the use of the atomic bomb?

Truman: There has always been active consideration of its use. I don't want to see it used. It is a terrible weapon, and it should not be used on innocent men, women, and children who have nothing whatever to do with

4 The Commander in Chief, Far East (MacArthur) to the Joint Chiefs of Staff, November 28, 1950, FRUS 1950, Vol.7, p.1237; The Commander in Chief, United Nations Command (MacArthur) to the Joint Chiefs of Staff, November 30, 1950, FRUS 1950, Vol.7, p.1260.

5 Crane, American Airpower Strategy, p.57.

6 The President's News Conference, November 30, 1950, PPHST, accessed on June 17, 2009. 
this military aggression. That happens when it is used. ${ }^{7}$

A few moments later, the topic was again jumped upon by the assembled press corps:

Journalist: Mr. President, I wonder if we could retrace that reference to the atom bomb? Did we understand you clearly that the use of the atomic bomb is under active consideration?

Truman: Always has been. It is one of our weapons.

Journalist: Does that mean, Mr. President, use against military objectives, or civilian-

Truman: It's a matter that the military people will have to decide. I'm not a military authority that passes on those things.

Journalist: Mr. President, you said this depends on United Nations action. Does that mean that we wouldn't use the atomic bomb except on a United Nations authorization?

Truman: No, it doesn't mean that at all. The action against Communist China depends on the action of the United Nations. The military commander in the field will have charge of the use of the weapons, as he always has. ${ }^{8}$

The media immediately picked up on Truman's inflammatory statement, and interpreted it to mean that MacArthur would be given authority to use the A-bomb; an interpretation hardly dampened by a hasty State Department clarification. It stressed that the US was not about to launch a nuclear attack and that only the President retained the authority to launch such an attack, should such a thing be considered. ${ }^{9}$ As Truman later recalled: 'In spite of this assurance [the clarifying press release] that the use of the atomic bomb was still subject to my approval and that I had not given such approval, news reports persisted that I had threatened to use the A-bomb in Korea. ${ }^{10}$ Gaddis noted that the uproar caused by Truman's statements made it painfully apparent what the diplomatic costs of the decision to use the atomic bomb would be. ${ }^{11}$ Those costs became only too obvious in the days and weeks that followed, especially when Clement Attlee, no doubt influenced by a petition from one hundred members of his own Labour Party and concerned about any expansion of the conflict, invited himself to Washington for a hastily convened summit meeting.

Truman's statements_-whilst truthful, the administration had been considering the atom bomb—contradicted his previous answers. Some historians consider Truman's volte-face

\footnotetext{
7 Ibid.

8 Ibid.

9 Press Release, November 30, 1950, Papers of Harry S. Truman, President's Secretary's Files, HSTL.

10 Truman, Memoirs, Vol.2, p.396.

11 Gaddis, The Long Peace, p.118.
} 
to be a deliberate strategic move, made in response to the deteriorating military situation. Richard Betts described the statement as a 'tacit threat' to the Chinese, even though it was not intended as such at the outset. ${ }^{12}$ Bruce Cumings and Jon Halliday went further, and stated that Truman's outburst was a 'carefully weighed threat'. ${ }^{13}$ However, it was a bitter irony that shortly after his own statements, and prompted by the continued unauthorised press statements coming from MacArthur, Truman issued a Presidential order instructing diplomats and military commanders to cease any direct communications with the media. ${ }^{14}$

Despite the outcry surrounding the November 30 comments, Truman's administration continued to debate the utility of nuclear weapons. On the same day as the fateful press conference, the Army War Plans Division was recommending to Collins (through the atomically enthusiastic General Bolte) that atomic weapons, and the necessary support structures, should be positioned in Korea with immediate effect. ${ }^{15}$

On December 1 a Pentagon meeting of the most significant decision makers aside from the President—including Acheson, Bradley, Collins, Marshall, Nitze, and Walter Bedell Smith of the CIA - convened to debate the situation. Transcripts show the concern that existed about the state of panic induced in the UN by Truman's ill-considered remarks. Acheson felt that it was absolutely vital to the defence of Europe that confidence was restored. ${ }^{16}$

The military, in particular Bradley, thought it was unnecessary for the UN mission to hold any territory north of the 'waist' of Korea (see map, p.X). Indeed they opined that from a strategic point of view, the best option would be to abandon the Korean mainland entirely and retreat to the offshore islands. This withdrawal, however, would present a threat to Japan that, as the linchpin of US Pacific defence planning, was unthinkable. The real concern was the possibility of PRC, and possibly even Soviet, air forces being deployed for mass attacks on UN formations. Chinese air intervention would raise the question of hitting back at bases within the PRC itself which, as was surmised, might draw the USSR into the conflict. The JCS

12 Betts, Nuclear Blackmail and Nuclear Balance, p.35.

13 Halliday and Cumings, The Forgotten War, p.123.

14 Acheson, Present At the Creation, p.472.

15 General Charles L. Bolte to the Chief of Staff, US Army (Collins), 'Possible Employment of Atomic Bombs in Korea (JCS 2173/1)', G-3 091 Korea RD/TS, November 30, 1950, RG319, NARA.

16 Memorandum of Conversation, Notes of Meeting in JCS Conference Room, Pentagon, 8.30am, December 1, 1950, Papers of Dean Acheson, HSTL, p.1 
were resolute in their recommendation that in the event of Chinese air strikes, there should be restraint. Collins, in possession of the pro-bomb information provided by Bolte, twice issued the gloomy prediction that if massed air power was used against the UN, 'the only chance left to save us is the use or threat of the use of the A-bomb. ${ }^{.17}$

Bedell Smith offered a weak note of optimism opining that the USSR was probably not planning on an expanded war, but that it may be willing to consider it if 'they can bog us down in Asia. ${ }^{18}$ The meeting concluded that despite Korea being of little value to US strategic interests, the peninsula must be held. ${ }^{19}$

Truman was, at this time, speaking before Congress for further appropriations to the rapidly swelling defence budget. The President used his speech to further emphasise the US commitment to Korea and again insisted that the entire debacle in Asia was part of a master plan orchestrated from the Kremlin. The UN was 'fighting for freedom against tyranny' in order to prevent unopposed aggression in Korea from being 'an invitation to aggression elsewhere'. ${ }^{20}$ In a burst of rhetoric that was only to be expected from the President, Truman issued a veiled threat to the PRC, stating that the Chinese had 'acted presumably with full knowledge of the dreadful consequences their action may bring on them. ${ }^{21}$ In light of the 'consideration' press conference, this was a much more explicit threat to escalate the conflict with nuclear weapons, as opposed to the stumbling, unintended threat of the 'consideration' statement.

The possibility of having to make a total withdrawal from Korea was tangible at the very highest levels, as demonstrated by the comments of Bradley and others on December 30 . However, level-headedness prevailed for many of the most influential decision makers. In a December 3 meeting, Bradley in particular was against the A-bomb and an expanded war with China. ${ }^{22}$ Acheson was concerned with public perceptions of the administration: if Korea was abandoned there was a danger of the Truman government being remembered by history as 'the greatest appeasers of all time', even more vilified than Neville Chamberlain after Munich

17 Ibid, pp.4-5.

18 Ibid, p.4.

19 Condit, History of the Office of the Secretary of Defense, p.86.

20 Truman Speech to the Congress of the United States, December 1, 1950, Papers of George M. Elsey, HSTL, p.2.

21 Ibid, p.3.

22 Memorandum of Conversation by the Ambassador at Large, December 3, 1950, FRUS 1950, Vol.7, p.1324, 1331. 
in $1938 .^{23}$ However, Rusk pointed out that the United States was not actually at war with China, given that fighting was still taking place under the banner of the UN 'police action'. The US, he argued, was not committed to defeating the PRC. ${ }^{24}$ Collins was dispatched to Tokyo to consult with MacArthur, consultations that covered potential use of the bomb. ${ }^{25}$ MacArthur was unhappy about the restrictions placed upon his command and criticised the administration in comments to the media. ${ }^{26}$

These debates were coloured by intelligence reports provided by the CIA. The National Intelligence Estimate (NIE) of December 5 emphasised that the Chinese intervention was undertaken with full knowledge of the risk of general war and that the USSR would come to the aid of the PRC in the event of UN operations in Chinese territory. ${ }^{27}$ And, in a move signifying an awareness that atomic might be required, Truman signed off on an order to place the non-nuclear components of eleven bombs in storage on board the aircraft carrier Franklin D. Roosevelt, prior to its departure for the Mediterranean. ${ }^{28}$

On December 5, Major General James M. Gavin, Chief Adviser of Weapons in the Office of the Secretary of Defense, added fuel to the fire by making an impassioned public plea for the tactical use of the bomb. His entreaty appeared in many newspapers and was even entered in the august pages of the Congressional Record. At the same time he visited General Ridgway and asked him to intercede with Collins and the President by recommending that nuclear weapons be used in Korea. ${ }^{29}$

In his article, Gavin characterised the current policy of holding back from use as 'sheer idiocy' and castigated the 'cowardly appeasing policies of those in Washington. ${ }^{30}$ He argued that "The A-bomb is a sound military defense. What moral or political considerations are there in defending our beleaguered Army and marines with our A-bomb used against attacking

23 Ibid, p.1324.

24 Ibid, p.1327.

25 Schnabel, Policy and Direction, pp.283-284.

26 Ibid, p.284.

27 NIE-11 'Soviet Intentions in The Current Situation', December 5, 1950, DNSA

28 Memorandum for the President by James S. Lay, Jr., December 5, 1950, Papers of Harry S. Truman, President's Secretary's Files, HSTL.

29 Betts, Soldiers, Statesmen, and Cold War Crises, p.105. At this point, Ridgway was Deputy Chief of Staff for Administration.

30 Maj. Gen. James M. Gavin, 'Atom Bomb Seen Tactical Weapon If Blow Warrants Cost', entered into the Congressional Record by Harry P. Cain, December 15, 1950, CRS, 81/2, Vol.96, Pt.2, p.16590. 
troops? $?^{\text {131 }}$ The stress of his thesis was on tactical, not strategic, applications, using A-bombs on the battlefield to support troops in immediate danger. Given his experiences commanding paratroopers in World War II, Gavin's desire to offer the soldier on the ground as much aid as possible is understandable. However, it displayed a lack of foresight or wilful ignorance of the wider implications of the atomic bomb that were then being discussed by the very 'idiots' in Washington that he was railing against. This was an early salvo in a debate on the tactical use of the A-bomb that would become more intense as the Korean War dragged on. It is a topic that is returned to in subsequent chapters.

\section{The Congressional Reaction}

The reaction on Capitol Hill has been given brief mention in scholarly studies of nonuse. It is, however, important to give due weight to the reaction from Congress, as it was a constituency that, however much they may have liked to, the Truman administration could ill afford to ignore. Moreover, the GOP had been reinvigorated by its victories in the November elections - leaving the Democrats with a tiny majority in the House and defeating several highprofile names in the Senate-and now felt that it had obtained a mandate to vigorously contest the Executive's decisions. It is therefore vital to examine what was said during this hectic and confused period.

Congress exploded in an uproar. when news of the 'consideration' conference filtered out. Over the coming days many Congressmen and Senators spoke out on the issue, both on Capitol Hill and in the media. The recent Congressional elections-which had delivered a stinging rebuke to the administration—-bolstered the right wing, who opposed the primacy of the UN in Korea, the methods of Acheson, and the 'appeasement' of the communist world. ${ }^{32}$

Owen Brewster was one of the most vociferous proponents of expanded action, insisting that MacArthur, and not the administration, was in the best position to make the decision on whether or not to utilize the A-bomb. He also harked back to the popular myth for using the atomic bombs on Japan, claiming that the weapon could save many thousands of American lives. ${ }^{33}$ His line of reasoning led to a debate with Ralph Edward Flanders (R-VT), a

31 Ibid.

32 Casey, Selling the Korean War, p.133.

33 Owen Brewster, December 1, 1950, CRS, 81/2, Vol.96, Pt.12, p.16012. 
fellow Republican and supporter of American nuclear weapons development but also of moves towards multilateral international disarmament. Flanders insisted that the decision to use the A-bomb could not be made on purely military grounds and that any use of the bomb must be authorised through the $\mathrm{UN}^{34} \mathrm{He}$ further opined that Brewster was not looking beyond the initial temporary advantage that atomic bombing might offer, given the sheer size of the Chinese population. ${ }^{35}$

Democratic opinion could also vary and was not always anti-nuclear. Charles E. Bennett (D-FL) laid out a series of recommendations for resolving the situation in Korea, including an ultimatum to the PRC that they should cease their activities and withdraw their forces or have their cities bombed by conventional and atomic weapons. ${ }^{36}$ Eugene O'Sullivan (D-NE), a staunch defender of the administration, was wholeheartedly opposed to dropping the bomb on China and went on to criticise the 'extreme right wingers trying to cripple the nation' by their attacks on Truman and Acheson. ${ }^{37}$

Senators and Congressmen also made their feelings known to the public through the media. In a Chicago Daily Tribune piece, that-sticking to its right-wing, stridently anticommunist stance-framed the debate in terms of 'Red Chinese Hordes' and those opposing A-Bomb use as expressing 'dissent', Brewster was again at the forefront of aggressive posturing, stating that Chinese military installations should be struck and that 'We might as well have a showdown now. ${ }^{138}$ Brien McMahon disagreed with his old opponent, opining that many grave and important military, diplomatic and psychological factors must be taken into account when considering whether or not to use the atomic bomb. ${ }^{39}$ In a television interview on NBC's 'Meet The Press' programme, Wayne Morse (R-OR) stated that the A-bomb was not the answer to the military needs of Korea but that if there were no chance of peace, then it might be dropped 'some place'. That 'some place' was Russia, with which Morse felt that the US was effectively at war. ${ }^{40}$ And, speaking in Florida, Edwin F. Johnson (R-CO)—a member of the JCAE alongside McMahon—asserted that the 'time has come to use the atomic bomb

34 Ralph E. Flanders, December 1, 1950, CRS, 81/2, Vol.96, Pt.12, p.16012.

35 Ibid.

36 Charles E. Bennett, December 6, 1950, CRS, 81/2, Vol.96, Pt.18, p.A7498.

37 Eugene O'Sullivan, December 4, 1950, CRH (Appendix), 81/2, Vol.96, Pt.18, p.A7415.

38 NA, 'Congressmen Split on Use of Atom Bomb', Chicago Daily Tribune, December 1, 1950, p.5.

39 Ibid.

40 NA, 'Morse Urges Use of A-Bomb Only on Russia', Washington Post, December 4, 1950, p.3. 
in Korea. ${ }^{41}$

This debate demonstrates that not all pro-bomb members of Congress were of the same opinion. Some, such as Morse, recognised—without fully understanding the situationthat finding a use for the bomb in Korea was difficult and therefore lobbied for even more extreme action. Supporters of non-use of the bomb in the Korean context-for example McMahon—now started to express views that advanced beyond the materialist arguments and explicitly brought up the diplomatic and ethical concerns surrounding the weapon.

\section{The Public Reaction}

While members of Congress used the media to put forward their position, examining the reactions by consumers of media provides an additional layer of nuance to the study of non-use. Other works investigating non-use have briefly mentioned public opinion as related to the December outcry. It is, however, useful to delve into examples of what was said in the form of letters to the editor. Such an examination yields informative insights into the polarised nature of public opinion and how the American people-viewed through the lens of newspaper correspondence-reacted to the 'consideration' comments and therefore contributed to shaping thinking on the atom bomb.

The major news organs carried many letters from concerned members of the public in the aftermath of the November 30 press conference. A sample from those sent to the Washington Post and the New York Times reveals a spectrum of opinion on the matter. On the same day that Truman made his statement, the New York Times published a letter that argued an expanded war with China would further alienate the peoples of Asia from the Western world and addressed issues of diplomacy and appeasement by asking 'would a little conciliation at Lake Success be more devastating than a world-wide atomic war? ${ }^{\text {?2 }}$ Two contrasting letters were printed in the Washington Post of December 5. The first brought up the well-used canard that US troops were fighting with one hand tied behind their collective backs; the second doubted that the atomic bomb would bring the Korean War to a successful end and urged that the government allow MacArthur to attack bases in Manchuria with

41 NA, 'Time for A-Bomb Here, Sen. Johnson Asserts', Washington Post, December 2, 1950, p.4.

42 Charles D. Kepner, Letter, New York Times, November 30, 1950, p.31. Lake Success, a settlement in lower New York State, was the temporary home of the United Nations from 1946 until 1951. 
conventional weapons. ${ }^{43}$

J. B. Manbeck of Washington characterised the conflict as a 'battle between the white and yellow races.' Chinese and Russians were held up as 'brothers under the skin in the yellow race-and ready to exterminate the white race'. In conclusion, the overtly racist Manbeck asserted that the atomic bomb was doing no good in storage and the US must not hold back because of 'some ill-founded altruistic theory. ${ }^{14}$ The position of individuals such as Manbeck offers an insight into the extreme end of the pro-use spectrum.

The New York Times of December 10 offered a wide range of opinion. Some urged the government, in the name of humanity, not to be the first to use the A-bomb, while others, recalling Dunkirk during World War II, urged use of nuclear weapons to extricate US forces and avoid a humiliating debacle. ${ }^{45}$ For some, the decision to drop or not drop the bomb was based on a 'phony moral issue' and should be left up to the military commanders on the ground. ${ }^{46}$ A correspondent from Georgia wrote on December 11 that China could be defeated by dropping nuclear weapons. The writer did not blame European nations for being afraid of a potential Soviet invasion if general war was provoked, but America must be firm. ${ }^{47}$

Meanwhile, a series of opinion polls published during the first week of December illustrated the feelings of many Americans. It should be noted that data for all of these polls were collected in mid to late November, prior to the main Chinese intervention, but during the period when it was clear that the PRC was involving itself in the war. When it came to backing a move into China, a small majority of citizens were against such action, with forty-six percent of respondents saying that the UN should confine its activities solely to the Korean peninsula. ${ }^{48}$ In response to the Chinese State Radio declarations that if the United States used the atom bomb against Chinese cities, then it should expect the same thing in return, the question 'If the United States does get into a war with Communist China, do you think we should or should not use the atom bomb in China?' was asked. ${ }^{49}$ Forty-five percent of

43 L.R.K. and Don W. Rhoades, 'Reactions to Communist Aggression', Letters, Washington Post, December 5, 1950, p.16.

44 J. B. Manbeck, Letter, Washington Post, December 9, 1950, p.12.

45 Mary Kellog, 'Comments on the Far East Crisis', Letter, New York Times, December 10, 1950, p.E10; Horace S. Stewart, 'Comments on the Far East Crisis', Letter, New York Times, December 10, 1950, p.E10

46 Frederick Shannon, 'Comments on the Far East Crisis', Letter, New York Times, December 10, 1950, p.E10

47 R. D. Brown, Letter, Washington Post, December 11, 1950, p.8.

48 Gallup, The Gallup Poll, Vol. 2, p.950.

49 The implication from the Chinese radio broadcast was that, in the absence of the PRC having its own 
respondents believed the A-bomb should be used in the event of war with China, with a further seven percent stating that it should only be used as a last resort. ${ }^{50}$ The number of respondents who believed that the United States was actively fighting World War III remained reasonably constant when compared to figures from earlier in the year, with fifty-five percent of people believing that a global war was already under way. ${ }^{51}$

Another poll from early December indicated that use of the atomic bomb came second only by a narrow margin to withdrawing from Korea as an appropriate response to Chinese intervention. Twenty-eight percent of respondents favoured withdrawal, while twenty-seven percent favoured using the A-bomb, and twenty-five percent favoured intensifying conventional action against China. ${ }^{52}$ The absence of anything approaching strong leadership and coherent communication created a situation where the public, according to the State Department, doubted the abilities and leadership qualities of the top men in Washington. Truman was urged to assert himself and make some effort to bring members of the public whose opinions were malleable over to the government side. ${ }^{53}$

The figures from this period demonstrate a counterpoint to those in the opening stages of the war. Public opinion gained an edge of belligerence that was not apparent before, highlighted by the majority opinion being in favour of using nuclear weapons immediately. Faced with a concrete situation, that of a war with China, the public had executed a volte face and now demanded use. From June until early November, the public was in favour of using the weapon only in the abstract circumstance of a far-off general war. It is argued that the Chinese involvement indicated to many that the abstract had now become the concrete and therefore willingness to use the weapon immediately increased. Public opinion was, therefore, changeable and far from monolithic. This change in position may also help to explain Truman's tone on November 30. A previously abstract situation had suddenly become all too real, had increased his fear that a decision about the bomb might be required, and may even have triggered him into alluding to exactly that possibility, even though through the months

atomic capability, it would invoke the Sino-Soviet Treaty and call upon the USSR to use its nuclear arsenal.

50 Gallup, The Gallup Poll, Vol.2, p.950.

51 Ibid, p.951.

52 John E. Mueller, 'Trends in Popular Support for the Wars in Korea and Vietnam', The American Political Science Review, Vol. 65, No.2 (June, 1971), p.367.

53 Memorandum by the Assistant Secretary of State for Public Affairs (Barrett) to the Secretary of State and the Under Secretary of State (Webb), December 5, 1950, FRUS 1950, Vol.1, pp.423-424 
since the outbreak of war he had frequently refused to acknowledge the possibility.

\section{The Foreign Reaction}

The foreign reactions to Truman's comments on November 30 were immediate, vociferous, and critical. Across the globe allies, enemies, and non-aligned nations expressed condemnation, fear, and horror. Baron Silvercruys, the Belgian Ambassador, was one of the first Europeans to air his concerns when he asked Dean Rusk directly if the US was intending to use the weapon. Rusk, not wishing to rule out any strategic options, was ambivalent. ${ }^{54}$ The European and Commonwealth delegations at the UN also expressed apprehension about Truman's statement and hoped that the President had not meant what had been reported in the press. ${ }^{55}$ The European diplomatic corps echoed the sentiments of their peoples: widespread fear of global war; distrust of MacArthur; and repugnance at the thought of using the atomic bomb. ${ }^{56}$ Public opinion in Britain, for example, was said to be 'deeply troubled' over the overall situation in the Far East and the possibility of A-bomb use leading to a general war. ${ }^{57}$ In an attempt to assuage the British peoples' fear, Attlee announced that he would hasten to Washington to discuss the atomic question with Truman. ${ }^{58}$

Opinion in Europe was clouded in large part by the distorted reporting of Truman's conference. When news of his comments first started flashing around the globe, it was unclear that Truman was responding to the goading of journalists, rather than making a premeditated statement of policy. ${ }^{59}$ Less than three hours after the press conference, the French government stated that 'the Korean objectives are not important enough to justify the use of the atomic bomb' and asserted the primacy of the UN in decision making. ${ }^{60}$ French premier Rene Pleven met with Attlee on December 2 to discuss the Korean matter. The two leaders reached a broad agreement on the issues confronting them, with Attlee nominated to act as European

54 Memorandum of Conversation, by the Assistant Secretary of State for Far Eastern Affairs (Rusk), November 30, 1950, FRUS 1950, Vol.7, p.1266.

55 Memorandum of Conversation, by Mr. G. Hayden Raynor, Adviser, United States Delegation to the General Assembly, December 1, 1950, FRUS 1950, Vol.1, p.115.

56 Raymond Daniel, 'Commons Cheer Attlee Decision', New York Times, December 1, 1950, p.9.

57 The Chargé in the United Kingdom (Holmes) to the Secretary of State, FRUS 1950, Vol.7, December 1, 1950, p.1296.

58 Laurence Burd, 'Attlee Will Visit Truman', Chicago Daily Tribune, December 1, 1950, p.1.

59 Drew Pearson, 'A-Bomb Remark Shocks British', Washington Post, December 5, 1950, p.B15.

60 Harold Callender, 'Paris Is Opposed to Atom Bomb Use', New York Times, December 1, 1950, p.4. 
spokesman in the imminent discussions with the United States. ${ }^{61}$

David Bruce, the US Ambassador to France, cabled his detailed thoughts on the situation back to Acheson. He described an increasing feeling in Europe that Britain and France must exercise a moderating influence on US ambition in Asia. ${ }^{62}$ Bruce noted European fear of a Soviet thrust West and feelings that 'due to geographic and psychological factors the US might decide more lightly about war and peace. ${ }^{163}$ In a similar vein, the State Department further concluded that Western Europeans were 'frightened to death that we are going to bluster into a general war'. ${ }^{64}$ Europe, it seemed, was no longer content to let the United States take the lead in Asia and must now exercise a restraining influence on their superpower ally.

In order to understand the sharply contrasting views of the A-bomb held in Europe and America, it is important to note the difference between the two peoples' experiences of war in the twentieth century. Huge swathes of Europe were devastated in two world wars that wiped out entire populations. America, while participating in both world wars, remained untouched by the widespread destruction that afflicted Europe: other than combat deathswhich numbered in the low hundreds of thousands and stood scant comparison to the tens of millions of deaths suffered by the Soviet Union—and the attack on Pearl Harbor, America was left alone by the ravages of war. In the United States, soldiers went to war and then came home. In Europe, war came to them. Therefore, the American experience of large-scale war, on the political, military, and public levels, was radically different to the experience of European nations who suffered through blitzkrieg and area bombing. Finally, if World War III did break out, the ground war would take place in Europe, not in North America.

The UN headquarters at Lake Success were abuzz with speculation. Delegates once again identified that the use of atomic weapons could not be based solely on political and military considerations, but that consideration of the moral element must enter into the decision making process. ${ }^{65}$ The European point of view also received backing from Canadian External Affairs Minister Lester Pearson, who expressed fear regarding the risk of major war

61 Clifton Daniel, 'French and British Leaders Meet In London', New York Times, December 3, 1950, p.1.

62 The Ambassador in France (Bruce) to the Secretary of State, December 5, 1950, FRUS 1950, Vol.7, p 1388.

63 Ibid, p.1389.

64 Memorandum by the Assistant Secretary of State for Public Affairs (Barrett) to the Secretary of State and the Under Secretary of State (Webb), December 5, 1950, FRUS 1950, Vol.1, p.423.

65 A.M. Rosenthal, 'U.N. Circles Wary on Atom Bomb Use', New York Times, December 1, 1950, p.5. 
and highlighted the centrality of Europe as a theatre of future world war. The cost of using the atomic bomb was too high for Pearson to contemplate, and the potential for use could destroy UN and NATO unity. ${ }^{66}$

Like the Europeans, Asian nations feared the repercussions of Truman's outburst. Their reaction was almost exactly that anticipated by the Bureau of Far Eastern Affairs in the November memo to Rusk. US diplomats reported widespread revulsion throughout the Middle East and Asia at the thought of the A-bomb being used and noted the disastrous effect that any such use would have on support for the United States. ${ }^{67}$ However, unlike the Europeans, who focused on the moral dimension of the bomb, Asian peoples viewed the Abomb as an implicitly racist weapon.

Speaking frankly to Eleanor Roosevelt at the UN (who reported her meetings back to the State Department), the Saudi Arabian delegate Dr. Jamil Baroody informed her that the nations of the Near East and Asia were 'profoundly distressed and disturbed' by the apparent sabre-rattling emanating from Washington. ${ }^{68}$ Baroody emphasised that the word 'possibly' in Truman's statement would disappear by the time the information reached the news stands in Asia: they would only hear that the US intended to use the bomb against another group of Asian people. Use of the atomic bomb against China would be seen as an 'action of the white race against the coloured race' which would have a 'disastrous effect upon the relations of the United States with the rest of the world for years to come. ${ }^{169}$ Members of the Indian and Pakistani delegations collectively agreed that Truman's words 'would reinforce idea US [was] willing [to] use mass destruction methods on Asians but not Europeans [sic]. ${ }^{170}$

Indian Prime Minister Jawaharlal Nehru also perceived the A-bomb as racist and, as de facto leader of the non-aligned nations, was one of the most prestigious Asian critics of Truman's statement. Like so many others, he believed that any use of nuclear weapons made an expanded war inevitable and anxiously offered his help to avoid any further deterioration in

66 Stairs, The Diplomacy of Constraint: Canada, the Korean War, and the United States, Toronto, 1974, pp.148-149.

67 Wittner, One World Or None, p.261.

68 Memorandum of Conversation, by Mrs. Franklin D. Roosevelt, Member of the United States Delegation to the General Assembly, December 1, 1950, FRUS 1950, Vol.1, p.116.

69 Ibid.

70 The United States Representative at the United Nations (Austin) to the Secretary of State, December 1, 1950, FRUS 1950, Vol.7, p.1300. 
international relations. ${ }^{71}$ The US ambassador to India reported that in off the record discussions, Nehru was 'vehemently denouncing any suggestion of use of atomic weapons' and was aggressive in his condemnation of the decision to cross the 38th parallel, with MacArthur singled out for particular criticism. ${ }^{72}$

China, the nation seemingly most at risk from an American atomic attack, seemed remarkably calm compared to her Asian neighbours. Ambassador Panikkar-although personally concerned that the United States, in a fit of desperation, may drop atomic bombs on Manchuria—noted that the Chinese seemed totally unaffected by what Truman had said. ${ }^{73}$ Senior soldiers and politicians had concluded in August that America had to think twice before using atomic weapons because of world-wide opposition to the nuclear option. ${ }^{74}$ Though the PRC stepped up its anti-American propaganda and supposedly constructed nuclear shelters around Beijing, little was made of the announcement.

Assessing the precise influence of foreign opinion is a challenging task. It is easier to relate the foreign opinion issues to concrete policy matters, such as the maintenance of a broad-based consensus regarding containment of the communist world. It is contended that while the precise mechanisms for influence are opaque, the mere fact that the US government paid so much attention to matters of foreign opinion is an indicator that such opinion exerted influence upon decision making. Truman and Marshall both opined that American strength and the preservation of containment in the Asia-Pacific theatre were key to 'securing their [Asian nations] good opinion'. ${ }^{75}$ It is therefore clear that foreign opinion was foremost in the minds of officials at the very highest level.

\section{The Truman-Attlee Meetings}

While the Truman administration broadly favoured non-use, they did not wish to be associated with the charge of 'appeasement.' Prior to the arrival of Attlee in Washington on December 4, figures within the administration were already scheming as to how they could use

71 Memorandum of a Telephone Conversation, by the Assistant Secretary of State for United Nations Affairs (Hickerson), December 3, 1950, FRUS 1950, Vol.7, p.1334.

72 The Ambassador in India (Henderson) to the Secretary of State, December 4, 1950, FRUS 1950, Vol.7, p.1344.

73 Panikkar, In Two Chinas, p.116-117.

74 Du Ping, 'Political Mobilization and Control', in Li et al (eds.), Mao's Generals Remember Korea, p.63.

75 Acheson, Present at the Creation, pp.481-482. 
the meeting to deflect accusations of 'appeasement' onto the British. Ever since the events leading up to World War II, appeasement was a dirty word in international relations. Bernard Baruch, a key advisor to Truman, passed a message to Acheson where he outlined means by which accusations of appeasement might be redirected from Truman, Acheson or Marshall on to Attlee. He suggested that Truman mention to Attlee that the American people were becoming so outraged with the situation in Korea that there were on the edge of demanding the A-bomb be used. ${ }^{76}$ This information would 'terrify Mr. Attlee' and lead the British Premier to finding some form of 'appeasement'. In the words of Baruch, 'it would be Mr. Attlee who would be the 'devil' and insist on some sort of workable plan of appeasement. ${ }^{77}$ Baruch's idea was floated in a meeting the next day between Truman, Acheson, Marshall, and Bradley. This time it was Marshall who suggested that, rather than US officials having to 'bear the burden' of making moves towards appeasement, they could somehow manoeuvre Attlee into making the first moves. ${ }^{78}$

Attlee could not have worked out that A-bomb use was broadly ruled out by the administration and discussion of the weapon was one of the key topics in the series of crowded Anglo-American meetings. Even when thrashing out far reaching diplomatic and military issues with other world leaders, Truman remained characteristically irascible. Under pressure from elements in Congress disturbed at what they perceived as meetings of international importance being held behind closed doors, he confided in Attlee that these were 'men who saw nothing wrong in plunging headlong into an Asian war. ${ }^{179}$ He reminded Attlee that the US and the UK had always been partners in atomic matters and that he would not consider using the bomb without first consulting the British government. When pressed for something in writing, Truman responded that 'if a man's word wasn't any good it wasn't made any better by writing it down. ${ }^{180}$ Attlee politely demurred. The US officials expressed a desire not to use the bomb and an awareness of the awful worldwide consequences of the atom

76 Annex to Memorandum of Conversation with Under Secretary Lovett, December 2, 1950, Papers of Dean Acheson, HSTL.

77 Ibid.

78 Memorandum of Conversation, by the Ambassador at Large (Jessup), December 3, 1950, FRUS 1950, Vol.7, p.1313. After the Truman-Attlee meetings, Senator William F. Knowland (R-CA) declared himself shocked and saw within the communiqué 'the making of a Far Eastern Munich', once more harking back to the appeasement of Nazi Germany [Acheson, Present at the Creation, p.485].

79 Truman, Memoirs, Vol.2, p.409-410

80 Memorandum for the Record, by the Ambassador at Large (Jessup), December 7, 1950, FRUS 1950, Vol.7, p.1462. 
bomb. ${ }^{81}$ Such statements did not, however, prevent Attlee from attempting to gain more concrete commitments that the weapon would not be used.

The delegates at the US-UK conference eventually agreed upon a joint communiqué that waxed lyrical about the two nations' common aims of maintaining world peace, promoting the principles of democratic freedom, and the key role of the UN. Only in the penultimate paragraph were the words 'atomic bomb' mentioned:

The President stated that it was his hope that world conditions would never call for the use of the atomic bomb. The President told the Prime Minister that it was also his desire to keep the Prime Minister at all times informed of developments which might bring about a change in the situation. ${ }^{182}$

Under the diplomatic language and mutual expressions of unity, the United States managed to retain freedom of action. No promise had been made that the UK, or any other nation, was able to directly influence the decision to use the A-bomb. They would merely be kept informed. Despite Attlee's best intentions, the US still had carte blanche to deploy its atomic arsenal in Korea.

Although Attlee had failed to prise any commitment from Truman, he still felt that he had achieved a significant diplomatic victory. Upon his return to the UK, Attlee stood at the dispatch box and told the House of Commons that:

As far as the use of atomic weapons is concerned, I can tell the House that I was completely satisfied by my talk on this question with the President. I would ask the House to accept my assurance that there is no difference of opinion between us on this vital matter. ${ }^{83}$

Many years later, Attlee was asked if there was a serious danger of MacArthur using the atomic bomb in China. The former Prime Minister responded that he thought such an outcome quite possible. Then did he think that his intervention prevented the war going nuclear? 'I think it quite likely,' he answered 'but I can't say. ${ }^{184}$

81 Memorandum for the Record, by Mr. R. Gordon Arneson, Special Assistant to the Secretary of State, January 16, 1953, FRUS 1950, Vol.7, p.1465. This particular entry was created in 1953 to note certain happenings at the Truman-Attlee conference and was subsequently included in the 1950 FRUS collection.

82 Joint Statement Following Discussions With the Prime Minister of Great Britain, December 8, 1950, PPHST, accessed on September 25, 2009.

83 Visit of the Prime Minister to the United States, Communiqué of 8th December, 1950, and Extract from House of Commons Debate of 12th December, 1950, House of Commons Parliamentary Papers On-line, p.7.

84 Clement Attlee, quoted in Denis Pitts, Clem Attlee: The Granada Historical Records Interview, London, 1967, p.46. 
Truman held a different view to his British counterpart. In a private diary entry from December 9, Truman once more revealed his fears about the imminence of a destructive global conflict. The President wrote 'I've worked for peace for five years and six months and it looks like World War III is here. I hope not—but we must meet whatever comes—and we will. ${ }^{85}$ Again we see the conflict that plagued Truman until the very end of his presidency: an overwhelming desire not to use the bomb but a recognition that, under certain circumstances, he may have to make the decision he feared most.

\section{CONCLUDING REMARKS}

The crisis surrounding the Chinese intervention in Korea stimulated the most serious public debate about the atomic bomb during the course of the war. While consideration had been ongoing since the earliest days of the conflict, senior officials were reticent to talk extensively about the possibilities for atomic war. Prior to his November 30 outburst, Truman had assiduously avoided answering media questions about the A-bomb. With a few seconds of ill-considered verbosity, he had thrown the debate wide open. Here was the man with his finger 'on the button' talking openly about the use of a weapon which cast a dark shadow across the world. Yet restraint was exercised.

Dingman asserted that US restraint was a product of changes in military, psychological, and political circumstances since the summer of $1950 .{ }^{86}$ He suggested that its reluctance probably mirrored doubts about the intentions from Beijing and uncertainty about the effectiveness of atomic weapons against relatively small units of enemy forces. ${ }^{87}$ The materialist argument that the weapons were not usable in Korea fails to account for a broad range of other, equally important, factors. Domestic and foreign public opinion played a crucial part in the decision not to use the bomb as did the now pressing fear of expanded war. We also cannot ignore the restraining influence of the UN, and Truman's personality.

Tannenwald offered a more compelling argument: that the state of domestic and world opinion made it difficult, if not impossible, for the administration to consider using atomic weapons. Foreign opposition, led by the UK, constrained the US because in the event

85 Truman, quoted in Ferrell (ed.), Off the Record, p.204.

86 Dingman, 'Atomic Diplomacy', p.66.

87 Ibid. 
of a war with the USSR, America needed British airbases to launch many of its atomic strikes. ${ }^{88}$ As a result the United States was forced by necessity to come to accommodations with its European allies. Taking unilateral action against North Korea or China with atomic weapons would have opened a serious rift between the allied states, potentially threatening the bonds of both the UN and NATO. Foreign opinion and foreign relations were, therefore, both great restraining influence on the decision making process during this time of great crisis.

Timothy Botti stated that Truman's private comments to Attlee during the conference were another gaffe that required resolution by Acheson and others. ${ }^{89}$ While Truman may have mis-spoken to a certain extent, it shows a lack of critical thinking to simply position his remarks as foolishness. They offer a valuable insight into his mindset at the time-something which Botti comprehensively ignored in his largely non-analytical account of the period-and expose the underlying 'terrain' of non-use that existed beyond the public consciousness.

The entire episode serves to give another example of the paradoxical situation that Truman was attempting to resolve in his own mind. His outburst told the world that he was thinking of atomic weapons. However, he was still desperately trying to avoid using them. His previous press conference statements show not a desire for government secrecy, but a desire not to confront the issue of atomic weapons. On November 30, with his explosive outburst, Truman demonstrated how much the issue bothered him.

The fracas surrounding Truman's wayward words led to something new. For the opening months of the war, the United States was firmly in charge. After, they found themselves under even greater scrutiny and pressure from other nations. Gaddis posited that the ill-considered remarks by Truman acted as a 'trial balloon' for the administration, demonstrating to Truman, Acheson and others what the response to A-bomb use would be before any serious consideration of use took place. ${ }^{90}$ The role of the bomb had been considered in the opening stages of the war, exemplified by the move of atomic-capable bombers to the UK and Guam. The period where Truman came closest to actual use would come in April 1951, by which time the administration had absorbed many of the lessons taught to them by the 'consideration' debacle. In this, Gaddis is correct in his assertion: the

88 Tannenwald, The Nuclear Taboo, p.130

89 Botti, Ace In The Hole, p.34.

90 Gaddis, The Long Peace, p.120. 
comments by Truman served as the starkest form of lesson for the US government.

Fear of World War III was a major influence on restraint. The idea that the world was about to run headlong into a another conflict, possibly even more destructive than World War II, frightened not only the government and military of the United States, but affected people around the world. It is important to stress, however, that another global war would not have been the nuclear holocaust that was feared from the nineteen-sixties onwards. With limited atomic weapons on both sides, the war would have been largely conventional in nature. It would, as Marc Trachtenberg asserted, be a long war of attrition between the Soviet and NATO forces with atomic weapons being a destructive, but limited, part of the conflict. ${ }^{91}$ However, the atomic bomb still loomed large in the public consciousness. It was the incredible secret weapon that had defeated Japan in 1945 and was touted as the first line of defence against the evils of Soviet expansionism. Public fear of the weapon and its destructive potential was entirely understandable, if somewhat at odds with the reality of a potential USUSSR confrontation. Truman, Acheson and Bradley had a greater understanding of what a major war with the USSR entailed for the United States and consequently held back from taking that step across the brink.

There were also other forces at work. The word 'appeasement', burdened with all the baggage of Munich, Chamberlain and the Nazis, began to crop up in the public and private discourse: administration officials, members of Congress and the general public all used the term. Truman and Acheson tried to appear 'tough' to fend off accusations of appeasement, especially in response to Republican attacks on their policy in China during the Civil War and their handling of the Korean conflict. The desire not to be seen as an 'appeaser' is amply illustrated by the discussions that took place prior to the Truman-Attlee meetings. Transferring the responsibility to Attlee would take the pressure off the administration and allow them to get on with the business of running the war.

The conjunction of the accusation of appeasement and the question of non-use or use of the atomic bomb is an interesting one, unexamined in the existing scholarship apart from a brief mention in passing by Tannenwald. ${ }^{92}$ In the eyes of many Americans, unaware of

91 Trachtenberg, 'A "Wasting Asset"', pp.21-22.

92 Tannenwald, The Nuclear Taboo, pp.130-131. 
the wider ramifications of the weapon, not using the bomb amounted to appeasement. Appeasement also connected those who engaged with it directly to communism: to appease was to become one with the communists, selling out America and the very ideals that the United States had gone to war for. The accusation provoked the administration to find ways around using the bomb and trapped Truman in the middle of two conflicting situations that had potentially identical outcomes, further contributing to the stressful mental situation he found himself in. Many who shouted the loudest about appeasement claimed that, based on the evidence of World War II, it only led to a global war. But it was also recognised within political and military circles that using the A-bomb would also lead to World War III. Appeasement accusations on the one hand, and the atomic bomb on the other, gave rise to the view that in order to avoid an expanded conflict, the war must continue to be fought, but fought on a limited scale. Rather than pushing the administration towards use, catcalls from the public galleries had the opposite effect and contributed to the push away from nuclear use by forcing them to limit the war while still aggressively confronting the communists.

On November 30, 1950, Truman-the individual-provided the catalyst for an outpouring of fear. In the final analysis, it was the reaction of massive groups, the people of Asia, Europe, the Middle East, and their representatives, that drove home the importance and significance of what was said. This episode is hugely significant as it exposed to public gaze the underlying discussions and tension regarding non-use. It also brought home to the administration the consequences of even mentioning the A-bomb and offered a glimpse of the denunciation that would come with actually using the weapon. 


\section{Chapter 3: 'Top Secret Malarky'}

The aftermath of the global outcry surrounding the November 30 press conference saw continued confusion over how to utilise US atomic superiority in Korea. The Chinese offensive pushed the UN forces back down the peninsula, inflicting upon American troops the worst defeat in their history. It was only in January 1951 that the allied forces halted, and then reversed, their retreat. Throughout this period the Truman administration exhibited enhanced awareness regarding the implications of loose talk about nuclear weapons. The State Department commissioned studies to examine in detail the attitudes of key allies in an effort to achieve greater understanding and avoid any repetition of the December débâcle. Senior officials in Washington also attempted to avoid sending out signals that might have indicated that atomic weapons would be used in and around Korea. And, an increasingly un-cooperative General MacArthur antagonised the administration by once more involving himself in the nuclear debate.

Scholars have given little attention to this period. Calingaert, Dingman, and Tannenwald all moved relatively swiftly from the fallout of Truman's press conference to his dismissal of MacArthur and the contemporaneous movement of nuclear weapons beyond the borders of the United States. However, examining in detail the broader picture of political, public, and foreign views shows that this period was of great importance. The opinions of influential scientific figures such as J. Robert Oppenheimer and Vannevar Bush only started to achieve traction in the popular consciousness from January 1951 onwards. For Dingman, the key months of December 1950-January 1951 and April-June 1951 dominated the debate. In many ways Dingman was correct in his assertion that these periods are important to comprehending why the atomic bomb was never used in Korea. However, the times before, during, and after these periods help to enhance our understanding of what takes place, showing a continuous thread of debate and analysis.

This chapter examines the period from mid-December 1950 until the end of March 1951, the phase of the war immediately between the outcry of early December and the dramatic firing of MacArthur in April 1951. It demonstrates that although the Truman 
administration had learned much about the international consequences of speculation about atomic weapons, they continued to strive for a way to use the A-bomb to bring about a resolution of the Korean War.

\section{INSIDERS}

\section{Gloom and Panic}

In mid-December, CIA intelligence briefings painted a gloomy picture of world events. The Soviets not only saw themselves as being in a position of great strength, it also appeared that Moscow and Beijing were conspiring to completely eliminate US influence in the Far East. The NIE of December 11, 1950 warned that the communist bloc had two goals: the establishment of China as the pre-eminent Asian power; and the reduction and eventual removal of Western influence in Japan. ${ }^{1}$ Intelligence analysts further estimated that it was the Soviet plan to undermine the 'Western will to use atomic weapons.'2

In the State Department, the grim news from Korea dominated discussions. Acheson wanted to see an end to the fighting and strove for some means to achieve this. Rusk had suggested on December 27 that there were three options facing them:

1. To win a military victory in Korea and stabilize the situation. This was not within our capabilities.

2. To make it in the interest of the Chinese Communists to accept some stabilization by making it so costly for them that they could not afford not to accept.

3. To get out in defeat voluntarily or under pressure and to continue our harassing tactics. ${ }^{3}$

Option two was preferred by Rusk but Acheson raised concerns about bringing the USSR into the war. Philip Jessup doubted that the Soviets would bring in air and sea forces to act against the UN unless they were willing to replicate this action on a worldwide basis, something that would precipitate a global war. ${ }^{4}$ Jessup also asked if it were possible to knock out the military installations at Port Arthur in China and Vladivostok in Russia. Rusk, echoing statements made by General Vandenberg on the first day of the war, said that it was only possible to do

1 NIE-15, 'Probable Soviet Moves to Exploit the Present Situation', December 11, 1950, DNSA, p.1.

2 Ibid.

3 Memorandum of Conversation, December 27, 1950, Papers of Dean Acheson, HSTL, p.4.

4 Ibid. 
so by using the atomic bomb. ${ }^{5}$

The President also received counsel from Admiral Alan G. Kirk, US Ambassador to the Soviet Union. Kirk's prognostication, based on his distinguished naval career and experience working in the political heart of the USSR, was less gloomy than most. He suggested that the chance of the Soviets provoking a global war was ' 3 to 2 against'. ${ }^{6} \mathrm{He}$ outlined the moves that might reduce these odds: the bombing of Chinese cities or the conspicuous weakening of US power and prestige by a defeat in Korea were two situations where the 'wise and canny' Stalin might see fit to precipitate a wider confrontation. ${ }^{7}$ Kirk concluded by saying that what the Soviets understood best was strength and determination. Truman replied that that was what he had been trying to display throughout his Presidency. ${ }^{8}$

In Tokyo, MacArthur grew increasingly panicky as the Chinese forces thrust down the Korean peninsula, with the UN armies retreating before them. Concerned that a communist victory in Korea would threaten vital US interests in Japan, he cabled Washington for additional forces. ${ }^{9}$ The General's feelings about the vulnerability of Japan were echoed by George Marshall, now Secretary of Defense, who acknowledged that the American people were aware of the difficulties of defending European interests, but would be shocked if they became aware of similar difficulties in Asia. ${ }^{10}$ Concurrently, General Vandenberg recommended that the U.S. initiate general hostilities with the USSR to pre-empt an inevitable global conflict: he felt that it was better for an expanded war to begin before the Soviets had time to build up their atomic stockpile. ${ }^{11}$

Despite the fact that the recommendations of Vandenberg gained little support, the prospect of a third world war dominated thinking. The worsening situation in Korea raised the possibility of a complete withdrawal of US troops from the peninsula. In the event of general war, the assembled politicians and soldiers wondered, would US forces be able to move safely and quickly to Japan? Furthermore, would the A-bomb be available to play any role in an

5 Ibid.

6 Memorandum of Conversation, by the Ambassador to the Soviet Union (Kirk), Temporarily in Washington, December 19, 1950, FRUS 1950, Vol.4, p.1278

7 Ibid.

8 Ibid.

9 Memorandum of Conversation, by the Assistant Secretary of State for Far Eastern Affairs (Rusk), December 19, 1950, FRUS 1950, Vol.7, p.1570

10 Ibid, p.1570-1571.

11 Ibid, pp.1572-1573 
expanded war in the Japan-Korea area ${ }^{12}$ The discussion raised more questions than it answered but foreshadowed the soon to be canvassed notion of having nuclear weapons ready and available for use in Asia.

\section{MacArthur Requests the Bomb}

MacArthur was not put off from his pessimistic analysis of the situation and on December 24 he issued his most explicit request yet for atomic weapons. He submitted to the JCS a list of 'retardation targets' that would require twenty-six bombs plus eight additional bombs for striking invasion forces and targets of opportunity. ${ }^{13}$ A great deal of debate has taken place over this move and the request has often been put forward as definitive proof of MacArthur's willingness to consider, and demand, the use of atomic weapons. John Lewis Gaddis argued-based on evidence from the official history of the US Army in Korea and the accounts given by D. Clayton James in his biography of MacArthur-that the assertion that MacArthur aggressively recommended their use is false and that he was merely reacting to requests from the JCS as to how such weapons might be used in the conflict. ${ }^{14}$ Yet the JCS response of December 29 does not explicitly mention the atomic issue but does state that 'Korea is not the place to fight a major war. ${ }^{15}$ However, MacArthur was reacting to JCS requests, dating back as far as the Bolte-Gruenther-Collins memo sequence of July-August (see Chapter One) and the visit of General Collins in early December (see Chapter Two). General Bolte had, in late July, wanted to gain the opinion of-and in fact supportMacArthur, stating 'it may be desirable that G-3 prepare a new cable to General MacArthur along the same lines as that originally forwarded to General Collins. ${ }^{16}$

Evidence uncovered while researching this thesis suggests that MacArthur was also influenced by another outside agency. On December 22 the Operations Research Office (ORO) at Johns Hopkins University, operating under contract to the US Army, submitted a report entitled 'Tactical Employment of the Atomic Bomb in Korea.' Produced for the

12 Ibid, pp.1575-1576

13 Records of the Army Staff, quoted in Foot, The Wrong War, pp.114-115. See also Crane, American Airpower Strategy, p.71.

14 Gaddis, The Long Peace, p.116n.

15 The Joint Chiefs of Staff to the Commander in Chief, Far East (MacArthur), December 29, 1950, FRUS 1950, Vol.7, p.1625.

16 Gruenther from Bolte, 'Use of the Atomic Bomb in Korea', p.2. 
Commander in Chief, Far East (MacArthur), this 183 page document demonstrates, in great detail, how, when, and why atomic weapons might be used in Korea. The bomb was categorised as 'a new, exceedingly powerful, and unique type of tactical weapon' that 'could be decisive in offense, defense, or disengagement. ${ }^{17}$ Paragraph twenty-nine of the report summary goes on to say that:

For decisive effect as an aid to withdrawal from a perimeter defense, such as the Pusan inner defense line, planning should be based on the allocation for possible use and shipment to the Command, but not necessarily the actual use, of 25 atomic bombs. ${ }^{18}$

The recommended number of bombs correlates closely with the figures given in the MacArthur memo of December 24. Given his fearsome work ethic, MacArthur could well have received and digested at least the basics of this report and therefore utilized its recommendations in his request to the JCS. This suggests that the General was influenced by the findings of 'defence intellectuals' such as those at ORO and therefore based at least some of his requests on what he perceived as scholarly, thoughtful analysis, as opposed to his own instinct to pursue an aggressive policy. Given the desire for his opinion expressed in the BolteGruenther-Collins memos and the December Collins visit, it can be speculated that there were at least two external influences acting on MacArthur: analysts in the United States providing pro-use intelligence; and the JCS in Washington scrambling to gain his views.

Tannenwald mentioned a similarly titled ORO report dating from March 1, 1951 but appears not to have consulted the original document and instead quoted Peter Hayes' reference in Pacific Powderkeg. ${ }^{19}$ Hayes gave little space to analysis of the document in his brief, and somewhat flawed, overview of nuclear issues during the Korean War. Only Timothy Botti took account of the December report, but failed to attach any significance to its timing, influence or the fact that it was compiled at the specific request of MacArthur's command. ${ }^{20}$ He offered a narrative of the contents but, as in the majority of his examination of the Korean conflict, failed to delve deeper into the implications of the document and give any

17 Ellis A. Johnson et al, 'Tactical Employment of the Atomic Bomb in Korea', Report to the Commander in Chief, Far East by the Operations Research Office, Johns Hopkins University, December 22, 1950, RG319, NARA, pp.6-7.

18 Ibid, p.8.

19 Tannenwald, The Nuclear Taboo, p.134n81; Peter Hayes, Pacific Powderkeg: American Nuclear Dilemmas in Korea, Lexington, 1991.

20 Botti, Ace In The Hole, p.36 
analysis. Viewing the December 1950 report in its context reveals, however, that key interests in Washington were influencing MacArthur immediately after the Chinese intervention.

MacArthur's request for atom-bombs on 24 December was closely followed by an equally forthright communiqué on December 30. The General was keen to involve Chinese Nationalist forces and chafed under restrictions which meant 'our naval and air potential are being only partially utilized and the great potential of Chinese Nationalist force on Formosa and guerrilla action on the Mainland are being ignored [sic]. ${ }^{12}$ Furthermore, he continued to advocate for action against China proper, a course which would lead to a general war. He called for a blockade of the Chinese coast and the destruction of 'China's industrial capacity to wage war' through naval gunfire and aerial bombardment. ${ }^{22}$ Given the massive land area and huge population of the PRC, only atomic bombardment could achieve what MacArthur was proposing. Conventional bombardment required immense numbers of planes, missions and bombs, making the A-bomb the only weapon that could economically deliver the desired results.

In Washington, Acheson reacted furiously to MacArthur's increasingly aggressive memos, characterising the General as 'incurably recalcitrant and basically disloyal to the purposes of his Commander in Chief. ${ }^{23}$ On the other side, MacArthur later characterised Truman, the administration, and the JCS as having lost the 'will to win'. To the veteran soldier, the orders coming from Washington amounted to nothing less than defeatism. ${ }^{24}$

\section{NSC-100}

As 1951 began, sabre rattling over Korea continued at the highest levels of government. On January 11, the famously aggressive chairman of the National Security Resources Board (NSRB), W. Stuart Symington, submitted NSC-100 to the administration. ${ }^{25}$

21 The Commander in Chief, Far East (MacArthur) to the Department of the Army, December 30, 1950, FRUS 1950, Vol.7, p.1631.

22 Ibid.

23 Acheson, Present at the Creation, p.515.

24 MacArthur, Reminiscences, p. 378.

25 Prior to heading the NSRB, Symington was the first Secretary of the Air Force from September 1947, until his resignation in April of 1950.His departure was in protest at the perceived lack of funding for the USAF in the face of new Soviet atomic capability. Symington was head of the NSRB when war broke out and participated in cabinet meetings. The NSRB was established by the National Security Act of 1947, the same act that established the CIA, JCS and NSC, to conduct long range economic and industrial planning and to co-ordinate military and civilian activities in the face of imminent Cold War crises. 
The paper presented a downbeat world-view, stating that the United States was in a 'war of survival'- both political and military-that it was losing. ${ }^{26}$ In order to begin winning this war and ensure the survival and dominance of the United States, NSC-100 baldly concluded that the way to re-assert American authority and help Western Europe to defend against Soviet expansionism was through the threat of atomic bombardment. Echoing MacArthur's requests from Tokyo, Symington recommended that the US should eschew the wasteful use of manpower in Korea, and instead use its naval and air supremacy to achieve victory. ${ }^{27}$ Symington advocated unilateral action by America if the UN refused to agree that China was the aggressor in Korea and give assent to retaliation against the PRC.

NSC-100 suggested Western Europe could be best defended by a doctrine indicating that any further Soviet aggression would result in direct atomic bombardment of the USSR. ${ }^{28}$ The results of this warning would supposedly be fourfold: it would demonstrate US leadership on behalf of the 'free world'; it would act as a deterrent to Soviet aggression; it would 'establish moral justification for use of United States' A-bombs in retaliation against Soviet aggression'; and finally it would 'afford the United States a measure of moral freedom that it does not now have to use the atom bomb under circumstances other than retaliation out of what might be left of this country after an initial Soviet atomic attack. ${ }^{29}$

Symington was unstinting in his praise for the atomic arsenal and its power to defeat or coerce enemies. If allies were lost because of this, then so be it: the United States would have established itself upon the moral high ground through action, rather than reaction. As scholar of atomic issues Gregg Herken accurately points out, NSC-100 was 'essentially an ultimatum to Russia and a prescription for a preventative war with China. ${ }^{130}$

Within the upper echelons of the government, there was little, if any, support for such extremism. Symington was seen by influential policy planners like Nitze as nothing more than a 'doom and gloom prophet'. ${ }^{31}$ In discussions about NSC-100 Acheson argued that any actions of the kind Symington recommended would immediately bring about World War III,

26 NSC-100, 'Recommended Policies and Actions in Light of the Grave World Situation', January 11, 1951, President's Secretary's Files, Papers of Harry S. Truman, HSTL, p.1.

27 Ibid, p.2.

28 Ibid, p.4.

29 Ibid.

30 Herken, The Winning Weapon, p.335.

31 Nitze, From Hiroshima to Glasnost, p.109. 
something that the administration had been desperately trying to avoid for the past six months. ${ }^{32}$ The Secretary of State then went further, categorising the atomic bomb not as an advantage or an asset, but a political liability. Mindful of the wavering state of foreign opinion, he argued that the threat of A-bomb use would not worry enemies of the United States-as was amply demonstrated by China's intervention in Korea — but it would 'frighten our allies to death. ${ }^{33}$

Symington attempted to shore up his weakening position by pointing out that, thanks to propaganda—such as the Stockholm Peace Petition—coming from the USSR, many Americans were beginning to believe that the atomic bomb was somehow immoral. In a notable piece of circumlocution, he stated that the 'bomb doesn't have to be a political threat, but it could well be a political ace. ${ }^{134}$ Symington received limited support from General Bradley, who had some sympathy—-tempered by his habitual caution—for the views expressed in NSC-100. He wondered-no doubt thinking of the last paragraph of the Truman-Attlee communiqué - if the United States had not been placed in a disadvantageous position by announcing that it would not use atomic bombs. ${ }^{35}$ Acheson and Truman were firm in their belief that no such definitive statement had been made. ${ }^{36}$ At the end of the meeting, it was decided that NSC-100 should be referred to the Secretaries of State and Defense for their consideration in joint meetings, a euphemistic way to pass the paper into bureaucratic obscurity.

Dean Acheson played an important role in consigning NSC-100 to the policy-making waste-paper basket. He understood very well that the atomic bomb was a decisive and critical issue in diplomacy that transcended military considerations. His comment that the A-bomb would 'frighten allies to death' offers a critical insight. It is as firm a statement of the influence that foreign opinion had on the Truman administration as any that has been discovered. It also amply illustrates that key individuals, such as Acheson, were only too aware of the complexities and subtleties of the nuclear issue. However, his position may reveal other underlying elements. Arguing that nuclear threats would cause irreparable rifts between the

32 Memorandum for the President, January 25, 1951, President's Secretary's Files, Papers of Harry S. Truman, HSTL, p.2.

33 Ibid.

34 Ibid, p.3.

35 Ibid.

36 Ibid, p.5. 
United States and vital allies could allow the Truman administration to shift the 'blame' for nuclear inaction on to foreign governments. It is not inconceivable that this strategy could have been used as an 'out', given its resemblance to the discussions prior to the Truman-Attlee summit, at which Acheson, Baruch, and Marshall suggested pinning the blame for 'appeasement' on the British Prime Minister.

Despite NSC-100 being blocked by Acheson, Symington continued to promote his aggressive thinking. In late January, he submitted a rambling paper to Truman that covered the history of national planning policy, the supposed failure of containment, the atomic stockpile, and many other subjects besides. ${ }^{37}$ He pointed out that containment had given the USSR the ability to dictate the time and direction of confrontations with the United States. He then continued to categorise the entire policy as 'dangerous and extravagant', inevitably leading to general war. ${ }^{38}$ At the end of the document, Truman scribbled 'My dear Stu, this is as big a lot of Top Secret malarky as I've ever read. Your time is wasted on such bunk as this. ${ }^{139}$

Symington became an increasingly marginalised figure after the failure of his proposals. However, as Gaddis noted, his comments should not be ignored as they 'did reflect a widespread sense within the government that the United States had failed to devise strategies for deterring limited aggression at a limited cost. ${ }^{140}$ Symington personified the fear and confusion within the administration at this time and is, therefore, a perfect example of why this period, when the position of non-use was never cut and dried, is vital to understanding future developments in planning and policy regarding the atom bomb.

\section{Ongoing Sensitivity and a Change in Fortunes}

More seriously than the near hysterical tone of Symington, participants in ongoing Department of State-JCS meetings fretted about Soviet capabilities. ${ }^{41}$ Could the USSR translate an atomic test explosion into a production programme substantial enough to threaten

37 Memorandum by the Chairman of the National Security Resources Board (Symington) to the President, undated, FRUS 1951, Vol.1, pp.22-33. This memorandum was unsigned and undated, but apparently passed to the President early in 1951. The compilers of the FRUS volumes have seen fit to place it between documents from January 23 and 24.

38 Ibid, pp.22-24.

39 Ibid, p.33.

40 Gaddis, The Long Peace, p.121.

41 Memorandum for the Record of State-Joint Chiefs of Staff Meeting Held in the Pentagon Building, January 24, 1951, FRUS 1951, Vol.1, p.34. 
the United States? Further intelligence on this matter was most certainly needed. ${ }^{42}$ Aside from the nuclear issue, the Soviet Union had more than enough conventional military force to overrun Western Europe, highlighting the understanding that any major war would be largely nonnuclear. Nervous allies were commented on, with the participants in the meeting agreeing that there was a view amongst nations aligned to the US that they were 'moving towards actions, particularly in Asia, which would greatly increase the danger of [global] war. ${ }^{\prime 43}$ Thus, the case for non-use was again reinforced by foreign opinion. And, related to the allied position, it was felt that foreign propaganda must be connected to a similar domestic policy in order to reassure the American public. ${ }^{44}$

The sensitivity of the atomic issue was highlighted on January 12 when Acheson was confronted with the possibility of General Curtis LeMay, head of SAC, making a visit to Korea. Vandenberg was planning a tour of inspection and proposed taking LeMay to garner his expert opinion on the situation. LeMay, as professional head of the atomic strike force, suggested that it would be wise to gain the approval of the Secretary of State. ${ }^{45}$ Acheson hurriedly summoned Vandenberg and made it plain that taking LeMay would send the wrong signal to the rest of the world. ${ }^{46}$ The SAC commander was known as 'something of a "Mr. Atom Bomb"' and that his presence in Korea would 'excite people unduly. ${ }^{17}$ Vandenberg agreed and departed without his subordinate. While LeMay did not go, the possibility that he might have illustrates the hold that atomic issues had over the imaginations of senior officials, particularly Acheson. After the fracas surrounding the 'consideration' press conference, anything that might provoke further worldwide opprobrium was pounced on before it got out of hand. The State Department was determined to keep the atomic bomb issue firmly under wraps.

By January 17, Vandenberg, in the company of Collins, had returned from his LeMayless trip to Korea and reported that the situation was much improved and the morale of the

42 Ibid, p.35.

43 Ibid.

44 Ibid, p.36.

45 Memorandum of Telephone Conversation, by Mildred Asbjornson of the Office of the Secretary of State, January 12, 1951, FRUS 1951, Vol.7, p.67.

46 Memorandum of Conversation, by Lucius D. Battle, Special Assistant to the Secretary of State, January 12, 1951, FRUS 1951, Vol.7, p.68.

47 Ibid. 
troops in a far better condition than MacArthur had suggested. ${ }^{48}$ By the end of March, with the re-invigorated UN troops once more reversing the flow of the conflict, the ROK returned to its pre-war boundaries. ${ }^{49}$ This advance, which continued slightly beyond the $38^{\text {th }}$ parallel, countered feeling that the Korean War could suddenly become a world war.

In terms of individual contribution to the evolving situation, it is vital to highlight the singular influence of General Matthew Ridgway. Upon assuming field command at the end of December, he had a freedom of action under MacArthur that his late predecessor, General Walker, never enjoyed. Ridgway was also blessed with an iron determination, considerable charisma, and great competence in command. His stabilisation of the situation in Korea and eventual switch from a retreating, defensive posture to aggressive, but thoughtful, offence gave hope to the troops on the ground and the administration in Washington. His achievement in turning around the fortunes of the battered UN armies and rebuilding their fighting spirit has been characterised as one of the 'great leadership accomplishments in military history. ${ }^{150}$ It is important to recognise that Ridgway was by no means anti-nuclear. As the war dragged on, he would be open to discussing the use of the A-bomb in extreme situations. However, this aspect is not relevant to his contribution during this period and will be discussed in Chapter Four.

This period, of a little over one hundred days, demonstrates how much the events of early December had influenced attitudes and positions within the administration. Extreme views, such as those of Symington, were sidelined. Potential publicity disasters, for example sending LeMay to Korea, were hurriedly quashed. And another vital actor in the form of Matthew Ridgway stepped onto the stage, thereby demonstrating yet again the power of the individual to influence decisions on atomic use or non-use.

\section{OUTSIDERS}

The opinions expressed by a range of groups and individuals outside the Truman administration showed a trend common across the entire period under study. Examining this

48 Acheson, Present at the Creation, p.516.

49 Stueck, Rethinking the Korean War, p.129-130.

50 Crane, American Airpower Strategy, p.67. 
trend, however briefly, is important to the overall understanding of non-use. In light of comments by senior government figures, such as Acheson and his concern that nuclear threats would 'frighten our allies to death', there is an obvious and important connection between insiders and outsiders that deserves further examination. ${ }^{51}$

\section{Congressional Opinion}

In the midst of defeat, a famous voice from America's past decided to pontificate on the perilous world situation. Former President Herbert Hoover, notable mainly for his failure to prevent a worsening of the great depression of the 1930's, addressed the nation with plans for preserving the western hemisphere. His December 20 address came at the time of comprehensive disaster for the UN forces in Korea, suffering ignominy after ignominy as they were pushed down the peninsula. The former president declared that 'the atomic bomb is a far less dominant weapon than it was once thought to be', tacitly criticising the vast expenditure on the atomic arsenal and SAC, and offering what seemed to be a covert endorsement of nonuse. ${ }^{52}$ Nonetheless, he called upon the UN to utterly condemn Chinese actions and support the United States in its fight to defeat communism. ${ }^{53}$ Furthermore, the 'feeble' nations of Western Europe should be encouraged and aided to defend themselves rather than being propped up by the crutch of American combat forces. ${ }^{54}$ Finally, he was a trenchant critic of 'appeasement'. For the ageing politician, 'appeasement contains more dangers than Dunkerques [sic]. ${ }^{155}$

Hoover's remarks received a mixed reception on Capitol Hill. Republican representatives, for example Howard Alexander Smith (R-NJ) and Clare Eugene Hoffman (RMI), lauded his comments. ${ }^{56}$ Others were less supportive. The ubiquitous Brien McMahon was quick to leap on the former president's assertion that the atomic bomb did not amount to very

51 Memorandum for the President, January 25, 1951, President's Secretary's Files. Papers of Harry S. Truman, HSTL, p.2.

52 Herbert Hoover, 'Text of Hoover's Speech on Preserving the Western Hemisphere', New York Times, December 21, 1951, p.22.

53 Ibid.

54 Ibid.

55 Ibid.

56 Howard A. Smith, December 22, 1950, CRS, 81/2, Vol.96, Pt.12, p.16956; Representative Clare E. Hoffman, December 22, 1950, CRH, 81/2, Vol.96, Pt.12, p.17017-17018. 
much, and expressed exasperation at Hoover's comment. ${ }^{57}$ Furthermore, he castigated Hoover for making a statement that was simply not the form of assurance that should be given to the American people. ${ }^{58}$

McMahon also lambasted scientist Vannevar Bush for publishing comments warning of America's lack of defence against a Soviet atomic bomb. Bush had been wartime head of the Office of Scientific Research and Development that administered the development of the atomic bomb until it was subsumed under Army control, and continued to advise the government on scientific issues. He claimed that new Soviet defences might be able to prevent US atomic bombers from reaching their targets. ${ }^{59}$ 'I do not think he knows what he is talking about' said McMahon from the floor of the Senate. ${ }^{60}$ These criticisms of Hoover and Bush received wide coverage in the news media.

Senator Frank P. Graham (D-NC), in a gloomy Christmas message published in the Washington Post, couched his thoughts on potential nuclear Armageddon in appropriately apocalyptic terms. In an article laid out in the manner of Bible verse, Graham offered up a plea for world peace, determination in the face of aggressive communism, and faith in the UN. ${ }^{61}$ Like many others before him, he also linked the events in Korea to the chances for global war and the long shadow of appeasement:

In the present complex world situation resistance to aggression in Korea or anywhere else may lead to global war. Appeasement of aggression leads no less surely and even more disastrously into another world war. ${ }^{62}$

As we have seen, the accusation of appeasement was one which had particular influence on the Truman administration. It was an allegation that Truman attempted to refute when, on December 15, he addressed the nation on the 'national emergency', stating:

We will continue to take every honorable step we can to avoid general war. But we will not engage in appeasement. The world learned from Munich that security cannot be bought by appeasement. ${ }^{63}$

57 Brien McMahon, December 22, 1950, CRS, 81/2, Vol.96, Pt.12, p.16961.

58 Ibid, pp.16961-16962.

59 NA, 'A-Bomb Strike May Be Near, Dr. Bush says', Washington Post, December 22, 1950, p.25.

60 Brien McMahon, December 22, 1950, CRS, 81/2, Vol.96, Pt.12, p.16962.

61 Frank P. Graham, 'Now Is UN's Time To try For Peace', Washington Post, December 25, 1950, p.9.

62 Ibid.

63 Truman, Radio and Television Report to the People on the National Emergency, December 15, 1950, PPHST, accessed on August 10, 2009. 
That those who wished to criticise the government continued to use such terms is unsurprising and serves to illustrate a trend that was apparent for some time to come.

The Hoover speech was also supported by Senator Robert A. Taft, a scion of the powerful political family and son of another former president, William Howard Taft. An opponent of Democratic progressive policies such as Roosevelt's New Deal and Truman's Fair Deal, of US entanglement in other people's quarrels, and an uneasy ally of anticommunist ideologue Joseph McCarthy, Taft was widely critical of Truman's handling of Korea. However, he was not a proponent of the atomic bomb as a means to 'win' the war. In public statements and private letters, he maintained the folly of use and the primacy of Europe as the theatre in which communism should be confronted: 'I think it would be a tragic error to use it against China, and I don't believe it would be successful in a land war operating over a 200-mile front. If we use it and it fails, we would be inviting Russian aggression in Europe. $^{164}$

Truman and his Cabinet received a jolt during the New Year in the form of a seemingly vituperative speech by Taft. In his January 5 remarks to the Senate, he declared that the atomic bomb provided a powerful deterrent to the USSR, but that the United States must not use the considerable power afforded by the weapon aggressively. ${ }^{65}$ Here was the most influential Republican essentially agreeing with the administration position on nuclear weapons. Unlike many outspoken GOP members, he was at the same time criticising and subtly supporting Truman's position and reinforcing the administration's inclination towards non-use.

Taft also refuted the position that the United States had found itself in by adopting the strategy laid out in NSC-68 (a paper he was unaware of the existence of). The lesson to be taken from Korea, he stressed, was that America could not afford to fight her enemies on battlegrounds of their choice. ${ }^{66}$ He saw US policy as being proactive against communist influence and threats, rather than being reactive, as was the case in Korea-a Republican parallel to the views espoused by Symington in his rambling late-January paper. The Senator was not advocating total withdrawal from European affairs, but did speak in favour of a quasi-

64 Robert A. Taft to Basil Brewer, Letter, December 6, 1950, in Clarence E. Wunderlin, Jr., The Papers of Robert A. Taft, Vol.4: 1949-1953, Kent (OH), p.221.

65 Senate Speech, January 5, 1951, in Wunderlin, The Papers of Robert A. Taft, Vol.4, pp.240-241.

66 Ibid, p.241. 
isolationist stance. Taft spoke for an important constituency within Republicanism, that of the conservative wing of the party. It was this wing that, aided by the election victories of the previous November and the outspoken anti-communism of the 'conspiracists' such as McCarthy and Kenneth S. Wherry (R-NE), was firmly in the ascendant. ${ }^{67}$

The speech provoked a vigorous debate. Taft himself suggested that the atomic bomb was not a useful tactical weapon in Korea. ${ }^{68}$ William Knowland brought up the by now familiar charge that UN forces in Korea were being forced to fight with 'one hand tied behind their backs. ${ }^{169}$ Wayne Morse once more latched on to the atomic issue, just as he had done in December of 1950, raising the worrying proposition that the USSR might eventually be able to produce more atomic bombs than the United States and hence wipe out American production facilities in the first stages of a war. ${ }^{70}$ Taft responded to this by firmly asserting that US bombers were longer ranged than Soviet bombers and atomic bomb production could easily keep ahead of the communists. ${ }^{71}$ He was broadly correct in this assertion. The USSR did lack an effective long-range bomber force, whereas American forces could rely heavily on forward air bases in Europe and the massive B-36 intercontinental bombers then coming in to service with the USAF.

Taft is an exemplar of how non-use cut across party lines. Although he was a critic of the Truman administration, he held views that were similar to those espoused by his targets. As acknowledged leader of the Republicans, he had genuine authority and influence. It is therefore significant, and informative, that his position aligned with that of the Truman administration.

Brien McMahon was as concerned as ever about the atomic issue. On March 7 he wrote to Acheson and asked whether or not 'the United States has made any commitment to any other nation which might serve to delay the employment of US atomic weapons after the President had decided in his own mind that he wished to use them. ${ }^{72}$ The continued influence of the Truman-Attlee communiqué and its ambiguous paragraph about decision-making over

67 Caridi, The Korean War and American Politics, p.101.

68 Robert A. Taft, CRS, 82nd Congress, 1st Session (hereafter 82/1), January 5, 1951, Vol.97, Pt.1, p.61-62.

69 William F. Knowland, Ibid, p.63.

70 Wayne Morse, Ibid, p.65-66.

71 Robert A. Taft, Ibid, p.66.

72 The Chairman of the Joint Congressional Committee on Atomic Energy (McMahon) to the Secretary of State, March 7, 1951, FRUS 1951, Vol.1, p.808. 
use of the atomic bomb was obviously still felt. Acheson responded in unequivocal terms: 'I wish to assure you that no such commitment exists.'. ${ }^{73}$

\section{Foreign Relations}

The State Department, after the outcry over November 30 and influenced from the top down by the position of Acheson, continued to demonstrate a keen interest in the European mood. The US was now aware that unilateral nuclear action in Korea, or against China, would trigger a worldwide backlash. The events of early December focused foreign opinion on the atomic issue to such an extent that American government officials were now required to pay much greater attention to the $\mathrm{UN}$ as an authorising agency for any expanded military action. The State Department therefore commissioned reports to ascertain the level of pro and anti-bomb sentiments in Europe.

On February 13, 1951, the Office of Intelligence Research (OIR) submitted a report to the State Department entitled 'Survey of Western European Opinion on the Atom Bomb as an Immoral Weapon'. The very title of this document is significant: the moral element of A-bomb usage was again brought to the fore and seen as a defining factor in the debate.

The report highlighted the perceived pernicious influence of communism in delegitimising atomic weapons, particularly through the attraction of the Stockholm Peace Appeal, which had gained far greater traction in Europe than in the United States. ${ }^{74}$ It also indicated that Western Europeans opposed the use of the atomic bomb because they feared widespread and indiscriminate destruction in a global war. ${ }^{75}$ For example, France was seen as exhibiting 'broad public repugnance' regarding use of atomic weapons and West Germany exhibited little faith in American ability to make a 'wise' decision regarding use. ${ }^{76}$ Austria, the Netherlands and the Scandinavian nations all saw the bomb as something horrific that, if used against China or in Korea could provoke World War III. ${ }^{77}$ Finally Italy was broadly against use, with the report citing the Italian newspaper Messaggero as expressing a hope that the bomb

73 The Secretary of State to the Chairman of the Joint Congressional Committee on Atomic Energy (McMahon), March 14, 1951, FRUS 1951, Vol.1, p.809.

74 'Survey of Western European Opinion on the Atom Bomb as an Immoral Weapon', Office of Intelligence Research Report No. CS 5.6, February 13, 1951, RG59, NARA, p.i.

75 Ibid.

76 Ibid, pp.6-9.

77 Ibid, pp.10-13. 
would not be used in the Far East due to 'elementary reasons of humanity. ${ }^{178}$ Thus, 'Europeans generally look upon the atom bomb as an immoral weapon to be used only when their very existence is clearly threatened'. ${ }^{79}$

As America's most important European partner, Britain received particular scrutiny in the report. Despite the close UK-US alliance, the British were politically and publicly against using the bomb in Korea, for reasons mainly of morality and fear of an expanded war, on account of the UK's extreme vulnerability to nuclear attacks from the USSR. ${ }^{80}$ They had good reason to be fearful: unlike the US, Britain was well within the range of Soviet bombers based in Eastern Europe. Part of Britain's antipathy towards the A-bomb was traced to the country's Labour government, which it characterised as 'extremely sensitive to the widespread popular alarm concerning the possible use of the A-bomb. ${ }^{81}$ The compilers of the report further drilled down in to the fine divisions of the Labour Party, noting that its pacifist and 'socialist left-winger' factions felt strongly that the atomic bomb was immoral and should be banned. Furthermore, these factions within the governing party doubted the ability of the United States to hold back from using the bomb due to America's 'militant political and military crusading spirit directed against Soviet communism and its allies. ${ }^{182}$

The survey thus gave the Truman administration a snapshot of European feeling about the atom bomb, and the response was overwhelmingly negative. This report offers a crucial insight into the seriousness with which world opinion was taken. In particular it demonstrated the general repugnance on the part of key allies regarding potential use of the atomic bomb. Faced by these dissenting views from America's closest friends, Truman had to think twice before deploying the atom bomb. The mere fact that the survey was compiled illustrates that in the post 'consideration' era the administration was keenly aware of world opinion and sought to modify its policy and behaviours based on external factors.

\section{Scientific Opinion}

From December 1950 to March 1951, scientists of many different stripes continued to

\footnotetext{
78 Ibid, p.14.

79 Ibid.

80 Ibid, p.4.

81 Ibid, p.1.

82 Ibid.
} 
make their feelings on the atomic issue known. An examination of some key cases demonstrates that debate on non-use was ongoing, and that the views of at least some scientists gained widespread attention.

The February 1951 issue of The Bulletin saw the publication of two significant articles on the tactical—that is, use on the battlefield against military targets—applications of the atomic bomb, an issue that had come to prominence as a result of events in Korea. Both articles were written by men of vastly different character and experience. Appearing first was 'Comments on the Military Value of the Atom' by J. Robert Oppenheimer. ${ }^{83}$ The second article was a reprint of General Gavin's December 1951 article on battlefield use of the atomic bomb that criticised the administration approach to tactical nuclear weapons in Korea. ${ }^{84}$ The timing of these articles—or in the case of the Gavin piece, the re-appearance of the article- highlights the importance of studying this period. Early December had brought the notion of the potential use of the A-bomb firmly into the public arena. The weeks following saw the rise of discussion on tactical uses of the bomb in public, as well as private, discourse.

Oppenheimer, then the Director of the Institute of Advanced Study at Princeton University, Chairman of the General Advisory Committee (GAC) to the AEC and advisor to the State Department on atomic energy matters was, as David Caute asserted, 'the most politically influential scientist in the nation. ${ }^{85}$ Oppenheimer stated that while atomic policy should not be dictated by the general public, it would be impossible for the President, NSC, and JCS to ignore public opinion related to the use of nuclear weapons. ${ }^{86}$ He endorsed the atom bomb as a tactical weapon for use in support of ground troops, a strong contrast to his outspoken anti-hydrogen bomb views. ${ }^{87}$ His abhorrence of strategic nuclear weapons use stemmed from several sources: a 'deep conviction that the Russian people are essentially victims of a tyrannical... government'; a distaste for the killing of civilians; and a feeling that

83 The Oppenheimer article was excerpted from an address given to the Association of the Bar of the City of New York on January 11, 1951.

84 The Gavin article has been covered in detail on pages 51-52.

85 Caute, The Great Fear, p.474.

86 J. Robert Oppenheimer, 'Comments on the Military Value of the Atom', The Bulletin of the Atomic Scientists, Vol.7, No.2 (February, 1951), p.44.

87 Ibid, pp.44-45. 
strategic bombing was crude and clumsy. ${ }^{88}$ Oppenheimer concluded by dwelling on the capability of the A-bomb to deter major war, noting the 'obvious horror' that an expanded war held for all people and emphasised that the atom bomb was, at least partially, a public and not simply governmental or military issue. ${ }^{89}$

Both Oppenheimer and Gavin endorsed the tactical use of atom weapons, but approached them in radically different ways. Gavin offered the practical, hard-headed opinion of a man who had seen combat during World War II and saw the A-bomb as a tool to save the lives of his fellow soldiers. Oppenheimer-arguably more than anyone the 'father' of the atomic bomb—was morally conflicted by its use to a far greater degree. While supporting the idea of tactical use under strict military circumstances, the thought of what he had unleashed on the world repelled and horrified him. Oppenheimer, like Brien McMahon, straddled the line between 'insider' and 'outsider'. His political influence and public standing made his a voice that was listened to. These cases, Gavin's positive stance and Oppenheimer's horror, demonstrated to the Truman administration that expert opinion could not be counted on to give wholehearted support to a particular position.

Comparison of these two cases also helps to illuminate another area: that of the material concern regarding the lack of targets in Korea. Tannenwald contended that those in favour of nuclear weapons (including weapons specialists such as Gavin) tended to see targets for nuclear weapons in Korea, whereas those who were anti-use tended not to see targets. ${ }^{90}$ The Oppenheimer position challenges this assumption. He saw a use for tactical weapons in Korea, but was massively conflicted at the same time (the December 1950 ORO report offers another example. The Johns Hopkins specialists were, it is argued, very much pro-use. However, they recognised that targets in Korea were practically non-existent and must be created by deliberate tactical manoeuvres on the ground). ${ }^{91}$

Oppenheimer was not the only scientist involved in the Manhattan Project to offer public statements on nuclear weapons. Despite his December mauling at the hands of Brien McMahon, on March 4, 1951, Vannevar Bush addressed the nation by radio in a speech that

88 J. Kenneth Mansfield, quoted in Kai Bird and Martin Sherwin, American Prometheus: The Triumph and Tragedy of J. Robert Oppenheimer, London, p.442

89 Oppenheimer, 'Comments on the Military Value of the Atom', p.45.

90 Tannenwald, The Nuclear Taboo, p.133.

91 Johnson et al, 'Tactical Employment of the Atomic Bomb in Korea', p.13. 
covered the defence of the 'free world', technological change, and the ability of the US atomic arsenal to prevent World War III. ${ }^{92}$ Bush stressed the deterrent power of the atomic bomb in the ongoing confrontation with the USSR, and credited the successful conclusion of the Berlin Blockade of 1948-1949 to confronting the Soviets with a show of strength. ${ }^{93}$ Strength, determination, and the threat of atomic attack, Bush contended, would continue to provide a barrier against Soviet expansionism and the threat of war. ${ }^{94}$ Headlines appearing in the Washington Post and New York Times focused on Bush's statements that the United States could, if provoked, defeat the USSR with its nuclear weapons: 'US Could Destroy Russia Now With A-Bombs, Dr. Bush Says' and 'Bush Says A-Bomb Can Wreck Soviet[s]' shouted the mastheads. $^{95}$

Throughout the coming month, Bush continued to receive publicity for his views, mostly variations on his March 4 address. Speaking in Philadelphia on March 14, he stated that the atomic bomb was the chief reason that there had been, since 1945, 'stalemate as far as all out war is concerned..$^{96}$ And, in Washington on March 21, he returned to the idea that nuclear bombs were a tactically viable battlefield option. He stated 'we can use the A-bomb tactically— that is, against enemy troops—-delivered by aircraft, guns, and guided missiles. ${ }^{97}$

While in public Bush upheld the notion of US atomic superiority as a bulwark against the Soviet threat and deplored the idea of a preventative, unprovoked strike against the USSR, it has been asserted by Steven Casey that in private, he held different views. Casey notes that Marshall, Nitze and others believed that the scientist was part of a group convinced that the US should use its nuclear superiority during 1951 due to the fading 'edge' it represented. ${ }^{98}$

The scientific discourse at this time is informative in that it demonstrates a clear split amongst influential figures whose views impacted on government policy. For example, as mentioned above, Bush was seen by key decision makers such as Nitze as having an extreme

92 Vannevar Bush, 'Text of Vannevar Bush's Address on Defense of the Free World', New York Times, March 5, 1951, p.9.

93 Ibid.

94 Ibid.

95 NA, 'U.S. Could Destroy Russia Now With A-Bombs, Dr. Bush Says', Washington Post, March 5, 1951, p.1; NA, 'Bush Says A-Bomb Can Wreck Soviet', New York Times, March 5, 1951, p.1.

96 Vannevar Bush, quoted in 'A-Bomb Fear Slows Russians, Dr. Bush Says', Washington Post, March 15, 1951, p.A3.

97 Vannevar Bush, quoted in 'Bush Says U.S. Can Use A-Weapons In Combat', New York Times, March 22, 1951, p.3.

98 Casey, Selling the Korean War, p.191. 
position, pushing for pre-emptive use of the A-bomb. The discussion was one that had been taking place within the scientific community ever since Hiroshima, but Korea had now forced that debate into the public domain.

\section{Public Opinion}

Letters to the major newspapers showcased the sometimes aggressive views of the American public. A correspondent writing to the Washington Post on December 16, in the midst of rout and retreat in Korea, recommend that the United States sell the Chinese Nationalists as many atomic weapons as they could use in order to have them drop the weapons on 'the Reds. ${ }^{199}$ Vannevar Bush's stance was warmly endorsed on March 9, where the views of the eminent scientist were contrasted with those of politicians, who had, the writer commented, brought the general public to 'the verge of near hysteria by cultivating fear of the big, bad Russian wolf.' ${ }^{100}$ Bush, on the other hand, was praised for offering 'warming reassurance' that the United States could destroy the Soviet Union with its nuclear arsenal. ${ }^{101}$

Fear of general war with the Soviet Union, and the opposing view that such notions were risible, was apparent in newspaper correspondence from December 1950 until March 1951. Some citizens thought that the USSR was not deterred by fear of the atomic bomb or by the build up of Western forces in Europe. ${ }^{102}$ Others opined that a statement should be issued to the Soviet Union that 'any further advance on her part in western Europe or in the Far East means war with the United States. ${ }^{103}$ The administration was called upon to hit the USSR before the opposite happened: 'That if we do not soon prepare and then launch our offensive,' a correspondent concluded 'an offensive on our terms and on battlefields selected by us and not the enemy, we may lose the war. ${ }^{104}$

Some displayed less militant attitudes, criticising Hoover and Taft for driving the world closer to a general war. ${ }^{105}$ The attitude that negotiating for peace represented weakness was attacked: 'Is compromise appeasement? Is a quid pro quo appeasement? Is common sense

99 I.H.F, "'Volunteer" War', Letter, Washington Post, December 16, 1950, p.10.

100 'Observer', 'Curb On Hysteria', Letter, Washington Post, March 9, 1951, p.B22.

101 Ibid.

102 H.E. Yarnell, 'Consolidating Our Defenses', Letter, Washington Post, December 29, 1950, p.18.

103 Ibid.

104 Nathan Siegel, 'On Losing The War', Letter, Washington Post, January 4, 1951, p.12.

105 Arthur Dunn, 'Confusion Over China', Letter, Washington Post, January 26, 1951, p.22. 
appeasement? ${ }^{106}$ And, the belief that the USSR was capable of a concerted atomic attack was vigorously disputed, with comments such as 'the danger of Russia invading America is infinitesimal' and 'the possibility of an atomic attack has been grossly exaggerated. ${ }^{107}$

Opinion polls once more demonstrated that public opinion was highly variable across time. In early January 1951, sixty-six percent of respondents thought that with China now fully involved in Korea, the United States should pull out completely. ${ }^{108}$ Yet at the end of January, with an improvement in battlefield conditions, public opinion underwent a remarkable turnaround: now, only twenty percent of those polled desired a pullout from Korea. ${ }^{109}$ A month later, another poll indicated that seventy-seven percent of the general public thought that America should not start an all-out war with China. ${ }^{110}$

But at the same time as Americans were expressing a desire not to get involved in an expanded war with China, two-fifths of them firmly believed that sometime over the coming year the United States would become involved in an 'all-out shooting war' with the USSR, even though Asia was still seen as a subsidiary battleground. ${ }^{111}$

Public attitudes towards use of the atomic bomb during the same period serve to highlight the belief that nuclear weapons were the cornerstone of US power. Should an 'allout shooting war' erupt between the two superpowers, sixty-six percent of Americans believed in pre-emptive atomic strikes against the USSR. ${ }^{112} \mathrm{~A}$ mere twenty percent believed that the Abomb should only be used in retaliation against an enemy atomic attack. ${ }^{113}$

These attitudes bear a remarkably similarity to those polled in mid-1950, before the PRC had become involved in the war. A substantial majority still believed that nuclear weapons should be used in the event of an expanded war, even to the extent of believing in pre-emptive usage. Further correlation can be found in the desire not to use the A-bomb in Korea. In December 1950, there was an edge of belligerence that had not been apparent in the early stages of the war. By January 1951, with things going very badly for the UN forces,

\footnotetext{
106 Ibid.

107 Frank E. Hess, 'Russian Bugaboo', Voice of the People, Chicago Daily Tribune, February 24, 1951, p.8.

108 Mildred Strunk, 'The Quarter's Polls', The Public Opinion Quarterly, Vol.15, No.2 (Summer, 1951), p.386.

109 Mueller, War, Presidents, and Public Opinion, p.76.

110 Ibid.

111 Strunk, 'The Quarter's Polls', p.393, 398-399.

112 Hazel Gaudet Erskine, 'The Polls: Atomic Weapons and Nuclear Energy', The Public Opinion Quarterly, Vol.27, No.2 (Summer, 1963), p.182.

113 Ibid.
} 
the number of respondents advocating withdrawal from the peninsula jumped dramatically. However, in the wider context of expanded hostilities, there was recognition that the bomb might have to be used.

John Mueller indicated that the December 1950/January 1951 period engendered the greatest expectations of world war during the entire three years of the Korean conflict. ${ }^{114}$ More than eighty percent of the population expected a major war within a decade, over sixty percent within five years, fifty-seven percent within two years, and forty-one percent within a year. ${ }^{115}$ According to Mueller, the Korean War caused 'the greatest fears of World War III' during the entire Cold War. ${ }^{116}$ Clearly, the fear and tension apparent since the outbreak of war had not abated and had only been reinforced by the Chinese intervention and the public discussion of nuclear weapons provoked by Truman's 'consideration' comments.

Examining domestic public opinion on use and non-use during this period is informative, as it demonstrates that the issue remained a constant in the public discourse. It is hard, however, to say that it was a major factor at this time. While no politician could afford to ignore public opinion, the relationship with foreign allies, such as the UK and France, was far more significant in determining US strategic policy. This makes for an interesting contribution to the overall picture of non-use. US politicians took far more account of foreign opinion than they did of domestic opinion when making vital decisions regarding nuclear weapons.

\section{CONCLUDING REMARKS}

If the period surrounding Truman's ill-timed 'consideration' comments can be characterised as the point in the Korean War when discussion of the atomic bomb burst fully in to the public domain, the aftermath, from mid-December 1950 to the end of March 1951, can be seen as a time of fear over the Chinese involvement in the war and increased awareness of the importance of foreign opinion. Criticism of the administration by the Republican Party—typified by the comments of Robert Taft—served to increase the pressure on Truman and his advisors. These three months also saw an increased emphasis on the tactical potential of the A-bomb, an emphasis that would become even more pronounced during the rest of

114 Mueller, 'Public Expectations of War During the Cold War', American Journal of Political Science, Vol.23, No.2, (May, 1979), p.304.

115 Ibid.

116 Ibid, p.315. 
the war.

The 'morality' of the bomb was analysed by domestic and foreign politicians and members of the public. As has been demonstrated, notions of morality penetrated the highest levels of the Truman administration. The State Department exhibited great concern about foreign attitudes towards the moral question, yet figures such as Stuart Symington argued that only through use of the bomb could the United States establish a moral legitimacy for the weapon. Symington's view failed to win the day because the President, heavily influenced by Dean Acheson, thought his policies far too extreme.

The fact that the State Department so heavily invested in ascertaining the views of other nations refutes the assertion by Calingaert that '[T] he Korean War confirmed the US policy of not allowing any outside restraints to limit American freedom of action in using atomic weapons.' On the surface, this is indeed true: there were repeated assertions that the Truman-Attlee communiqué had not restricted US freedom. However, looking beneath the surface shows that there were restraints acting on US policy, restraints that severely limit ed freedom of action.

The concept of appeasement and the use of the term by critics of the Truman administration are again worth noting. Republican attacks, such as that launched by former President Hoover, were once more couched in anti-appeasement language that tied compromise to pro-communist attitudes and the rocky road towards another global war. Conversely, some more nuanced views appeared from the general public, questioning and criticising the rightist linkage between fair compromise and Munich style appeasement of a wily enemy. In a manner similar to the fear of global war and questions of the morality of the A-bomb, the notion of appeasement and the use of the term to attack Truman and his allies show that threads of debate ran through the discourse of the entire war, little recognised by the existing scholarship.

The horrific spectre of an expanded war continued to dominate thinking. Fear influenced politicians, pundits, and public alike. The general feeling that atomic bomb use would lead to global war was only heightened by the military disasters of December and January. Yet at this stage, dealing with the greatest military defeat in American history, Truman chose to accept what would become a 'demoralising and bloody stalemate', rather than plunge 
the word into an atomic conflict. ${ }^{117}$ Only with the stabilising of the situation by Ridgway did fears that a larger conflict was on the horizon begin to diminish.

Reports and memoranda percolating through the State Department showed how the events of early December impacted governmental thinking and would go on to influence the handling of matters during the key period of April-June 1951. The violence of the world-wide reaction to the 'consideration' statements forced key groups and officials to re-assess the US position. Reports such as the February 13 paper on Western European opinion forcefully illustrate that the education of the U.S. government in how to handle atomic issues was an ongoing process. Furthermore, increased awareness of the provocative nature of atomic matters is clearly demonstrated by the internal 'flap' over the potential Vandenberg-LeMay trip to Korea. Dean Acheson showed a nuanced understanding of what message would be sent to allies and enemies if LeMay were allowed to visit the war zone. Despite Truman's gaffe, the US had not made any explicit threats to use the bomb. Sending the head of SAC to Korea would be another step closer to a direct warning of intent.

This chapter has also demonstrated that there were many external influences acting on Douglas MacArthur that have not been captured in previous work. The traditional position has been that MacArthur was highly aggressive when it came to use of the atomic bomb. In many ways, this is true. His remarks about using the A-bomb against Vladivostok in the very early stages of the conflict show a man willing to use all the forces at his disposal to win a war. Yet, the evidence presented in this chapter also shows that, despite the fact that his attitude towards the war was fundamentally at odds with that of the administration he served, that difference in view did not always extend to the atomic bomb.

Study of this 'interregnum period' repays close attention, as has been accorded it in this chapter. This attention demonstrates that the possibility of use was never entirely 'off the table' while also illuminating the complex mesh of outlooks and attitudes. Looking in detail at this period illustrates that there were serious moves to try and find ways to use the weapon, as well as moves to reinforce a position of non-use. Given the military disaster facing the UN forces, and the potential for being driven from the peninsula, the atomic bomb can be seen as

117 James Carroll, House of War: The Pentagon and the Disastrous Rise of American Power, New York, 2006, p.194. 
a likely response to such events. However, the case of Stuart Symington-to cite one key example-shows how little influence extreme positions on potential use had at this time. It is vital therefore, to look at this period as one where there was a crystallising of attitudes at the highest level, attitudes that were tending towards non-use. This can be coupled to the extreme public fear, the greatest level of fear measured during the entire war, that global conflict was about to break out. These facts make the events of April 1951, where potential use again came to the fore, even more startling. 


\section{Chapter 4: 'Prepare for Armageddon'}

Throughout his political career Harry Truman made some unpopular, but necessary, decisions. His public persona as the 'buck stops here' president positioned him as the man who bore ultimate personal responsibility for American actions. Arguably the decision that led to the greatest disapproval was the firing of General Douglas MacArthur on April 10, 1951. Terminating the five-decade career of a man seen by many Americans as their greatest living soldier saw public ire heaped upon Truman and his administration.

The period surrounding the dismissal of MacArthur has been the subject of considerable scholarly and popular debate. ${ }^{1}$ In any exploration of the question of use or nonuse during the Korean War, it is not so much the dismissal of MacArthur, but the circumstances surrounding it that loom large. Most importantly, this was the period when, for the first time since 1945, fully operational nuclear weapons were deployed beyond the borders of the United States. And how significant was it that Britain, the key American ally, underwent a subtle change of position on nuclear weapons use and, unlike the absolute opposition to use seen in December, tacitly agreed to using the A-bomb under certain circumstances? The United States and Britain could no longer simply be distinguished on the basis of an extreme British non-use posture.

This chapter covers the period from April to June 1951. It analyses the plans that moved the US to a position between use and non-use and how the administration navigated its way through this fraught period. In light of the administration's willingness to acquiesce to greater international scrutiny after the fracas surrounding the November 30 press conference, it also examines how the Truman administration and the US military reacted to foreign and domestic pressures.

1 For example, see: Richard Lowitt, The Truman-MacArthur Controversy, Chicago, 1967; John Spanier, The Truman-MacArthur Controversy and the Korean War, Cambridge (MA), 1959; Stanley Weintraub, MacArthur's War: Korea and the Undoing of an American Hero, New York, 2000. 
INSIDERS

\section{The Soviet Threat and the Firing of MacArthur}

In April 1951, UN forces prepared to cross the 38th parallel for the second time. Bolstered by General Ridgway, the allied armies pushed the communist forces back up the peninsula. There were, however, disturbing reports of Chinese plans for yet another offensive, backed by Soviet preparations to bring increased combat forces into the Asian theatre. ${ }^{2}$ This intelligence worried planners in Washington, with high ranking officers convincing the President that the USSR might take steps to ensure the US was expelled from Korea. ${ }^{3}$ Not only did the administration have to cope with the possibility of a massive Chinese attack, possibly with Soviet support, but they also needed to deal with the continued insubordination of MacArthur.

The General had toyed with the idea that the by-products of atomic weapons development could be used in place of A-bomb itself. In his memoirs, he recalled a midFebruary 1951 plan to 'sever Korea from Manchuria by laying a field of radioactive wastesthe by-products of atomic manufacture-across all the major lines of enemy supply. ${ }^{4} \mathrm{He}$ also made further controversial statements to the press. On March 23, in a comment that was bound to give the Chinese pause for thought, he stated:

The enemy must by now be painfully aware that a decision of the United Nations to depart from its tolerant effort to contain the war to Korea thru [sic] an expansion of our military operations to his coastal area and military bases, would doom Red China to the risk of imminent military collapse. ${ }^{5}$

By early April, MacArthur had taken the final steps that would lead to his dismissal. On April 5, Congressman Joe Martin (R-MA) read in Congress a private letter he had received from MacArthur. The letter called for expanded war bringing the Chinese Nationalists into the fight and using all the power of the United States to win the conflict. ${ }^{6}$ On the same day, MacArthur made inflammatory comments from Tokyo in which he protested against 'political interference' in the Korean campaign and that it 'was not the soldier who had encroached on

2 Gordon E. Dean, Office Diary, April 5, 1951, in Roger M. Anders (ed.), Forging the Atomic Shield: Excerpts from the Office Diary of Gordon E. Dean, Chapel Hill, 1987, p.127.

3 Crane, 'To Avert Impending Disaster', p.78.

4 MacArthur, Reminiscences, p.384.

5 NA, 'Gen. M'Arthur Opens Peace Door To Reds', Chicago Daily Tribune, March 24, 1951, p.1.

6 Acheson, Present At the Creation, p.520. 
the realm of the politician; the politician had encroached on that of the soldier. ${ }^{17}$ Faced with this insubordination, Truman catalogued a litany of abuses-such as an incendiary letter to the Veterans of Foreign Wars annual conference during the summer of 1950-in his diary on April 6. ${ }^{8}$ The comments of April 5, Truman bitterly noted, were 'the last straw.'

This latest development in his relations with MacArthur could not have come at a worse time. On the same day that Truman expressed his fury about the wayward general, he was also meeting with Chairman of the AEC Gordon E. Dean, to discuss the transfer of fully operational nuclear weapons into military custody and thence to Guam. Truman told Dean that the situation in the Far East was 'extremely serious', with huge numbers of Chinese soldiers massed on Korea's northern border. ${ }^{10}$ Intelligence indicated that aircraft were lined up, wing-tip to wing-tip on numerous airfields, awaiting the order to strike. The same reports suggested that there were concentrations of Soviet submarines around Vladivostok and Sakhalin. ${ }^{11}$ Truman thought that this intelligence clearly showed that 'not only are the Reds and the Russians ready to push us out of Korea, but [that they] may attempt to take the Japanese islands and with the submarines cut our supply lines to Japan and Korea. ${ }^{12}$

Fear that the USSR might be about to involve itself led directly to the first movement of complete nuclear weapons beyond the borders of the United States since 1945. Prior movements— such as the dispatch of weapon components to the UKnuclear elements of the weapons. Following the discussion with Dean, and in the face of what was perceived as a prelude to expanded war, Truman signed an order to transfer nine fully functional bombs from the AEC to the military in preparation for overseas deployment. ${ }^{13}$ Dean managed to obtain an assurance from the President that a 'decision to transfer was not a decision to use' and that any such decision was subject to discussion by the special atomic energy subcommittee of the NSC, made up of the President, the AEC Chairman, the Secretary of State and Secretary of Defense. ${ }^{14}$

During the weapons transfer process, Truman wanted to ensure that news of it not

7 NA, 'M'Arthur Urges End of Political War Meddling', Chicago Daily Tribune, April 6, 1951, p.3.

8 Truman, diary, April 6, 1951, in Ferrell (ed.), Off the Record, p.210.

9 Ibid.

10 Dean, diary, April 6, 1951, in Anders (ed.), Forging the Atomic Shield, p.137.

11 Ibid; The Secretary of State to Certain Diplomatic Offices, April 9, 1951, FRUS 1951, Vol.7, p.317.

12 Dean, diary, April 6, 1951, in Anders (ed.), Forging the Atomic Shield, p.137.

13 Ibid.

14 Ibid. 
reach the public. One potential conduit for such a 'leak' was the JCAE, to which Dean was obliged to report regarding the movement of weapons. Truman thought it 'highly important that word of this transfer not get to the full Committee at this time, as it was a highly sensitive military move designed to secure readiness and it was not something that should become subject to Congressional review. ${ }^{15}$ The President suggested calling Brien McMahon, chairman of the JCAE, to request discretion. Dean subsequently met with the Committee, informing them of Truman's assurances on non-use. ${ }^{16}$

On April 9, Marshall informed Truman that Bradley and the JCS-having been canvassed for their opinions on any potential action against MacArthur-had unanimously recommended the removal of MacArthur. ${ }^{17}$ The President, Acheson and Marshall all agreed this was the wisest course of action and selected Acheson to issue the fateful communication. A convoluted chain of communication disintegrated and the orders were transmitted through regular Army communications network, leading MacArthur and his supporters to feel that this was a deliberate slight. ${ }^{18}$ Ridgway was put in overall command, to the delight of many in Washington, and was succeeded as field commander by General James A. Van Fleet. ${ }^{19}$ MacArthur's perverse and often baffling relationship with civilian authority had come to an end as, for the first time in fourteen years, he returned to the United States.

\section{Clarifications}

Significantly, when Truman attempted to explain to an angry public the reasons for MacArthur's sacking, the issue of the atomic bomb was not mentioned. His press statement of April 11 detailed numerous examples of MacArthur's deliberate disobedience of direct Presidential orders placing strict limitations on what officials and officers could say in public, but did not reference the A-bomb. ${ }^{20}$ Truman had learned from the furore of early December.

On the same day Truman also delivered a lengthy national radio address on America's

15 Dean, diary, April 7, 1951, April 9, 1951, in Anders (ed.), Forging the Atomic Shield, pp.138-139.

16 Dean, diary, April 9, 1951, in Anders (ed.), Forging the Atomic Shield, p.140.

17 Acheson, Present At The Creation, p.522. At the time of his dismissal, MacArthur held the positions of Supreme Commander, Allied Powers in Japan; Commander in Chief, United Nations Command; Commander in Chief, Far East Command; and Commanding General, Army Forces Far East.

18 Ibid; Schnabel \& Watson, The Joint Chiefs of Staff and National Policy, Vol.3, Part 1, Wilmington, 1979, pp.544546.

19 Acheson, Present at the Creation, p.522; Hermes, Truce Tent and Fighting Front, p.13.

20 Truman, 'Statement and Order by the President on Relieving General MacArthur of His Commands', April 11, 1951, PPHST, accessed on July 29, 2009. 
Far Eastern policy. This did not mention the deployment to Guam either, but rather discussed the danger of an expanded war and his desire to prevent such an event no fewer than eleven times. He clearly wanted to frame his policy in Korea and the dismissal of MacArthur in terms of non-expansion and prevention of general hostilities: 'A number of events have made it evident that General MacArthur did not agree with that policy' he stated in relation to limited war and the prevention of expansion. ${ }^{21}$ Furthermore, the President stated that 'I have therefore considered it essential to relieve General MacArthur so that there would be no doubt or confusion as to the real purpose and aim of our policy. ${ }^{122}$

The concurrent decisions to relieve MacArthur and move complete atomic weapons from the AEC to the military are suggestive of the administration's intention to potentially utilise the weapons. Dingman argued that the firing of MacArthur and the atomic bombs were linked by matters other than coincidental timing. He maintained that the transfer of nuclear weapons to the military was essential for Truman to gain the support of the JCS in the dismissal of MacArthur. ${ }^{23}$ Certain parts of this are true: once the JCS had agreed to the sacking, the firing of MacArthur became intrinsically connected to the atomic bomb. However, given the professionalism and habitual caution of Bradley, the most senior of the Joint Chiefs, the thought of a 'bribe' being used to influence the situation seems remarkable. The dismissal was now, however, a matter of high policy, rather than Truman simply reaching the end of his tether. The JCS reached their decision as professional soldiers with an awareness of the global situation: MacArthur, with his unreliability and desire to expand the war, was not the best commander if the bombs were to be used. Ridgway was far more reliable, both politically and militarily.

Nonetheless, should Truman decide to use the bomb, whether tactically or strategically, he now had the weapons in place and a man in charge on whom he could rely. This demonstrates that, even in the mind of someone so ostensibly dedicated to non-use as Truman, the issue was never finally decided. It is an irony that when the man most likely to expand the war was removed from his position, the administration that was so concerned about global conflict was seriously examining options for just such an expansion.

21 Truman, 'Radio Report to the American People on Korea and on US Policy in the Far East', PPHST, accessed on July 29, 2009.

22 Ibid.

23 Dingman, 'Atomic Diplomacy', p.74. 


\section{New Orders and Covert Communications}

With Ridgway in overall command, Washington was determined to exercise an influence that it had signally failed to achieve with his predecessor. On April 18, Bradley and Collins were firm in their resolution to guide Ridgway on political matters, especially in respect of how far north to proceed, the very issue that had prompted Chinese intervention in the first place. ${ }^{24}$ Senior military figures were in total agreement with the civilian officials that, this time round, they should have a firm grip on the reins of command.

During the same discussion, the implications of an expanded war for relations with allies was also discussed. Nitze-supported by Bradley and Collins—noted that in the event of a major Chinese or Soviet air attack in Korea, the US should reserve the right to make a swift decision on retaliation, whilst maintaining the co-operation of the $\mathrm{UK} \cdot{ }^{25} \mathrm{He}$ commented that if the US chose to act alone, then they would 'have to face the consequences of unilateral decision and action'; without the UK, the United States would be left with few viable sites from which to launch attacks against any Soviet thrust into Western Europe. ${ }^{26}$ Thus, the relationship between the US and the UK continued to influence American nuclear strategy. As we will see, influence also went the other way.

In Tokyo, Ridgway was wrestling with similar issues. In a telegram to the JCS on April 27 , he requested permission that, in the 'event of a major enemy air attack from outside of Korea against United Nations Forces in the Korean area', he would be authorised to hit back at the bases from where the attacks originated. ${ }^{27}$ Ridgway was acutely aware of the chain reaction that could be started by expanding the war: in his orders to senior officers, he warned them of the 'grave and ever present danger' of expansion and stressed 'that every commander be constantly aware of this possibility'. ${ }^{28}$ The JCS responded with an April 28 directive giving Ridgway permission to carry out retaliatory attacks. They noted, however, that such attacks might 'set in chain a course of events making it of the utmost importance to have the support

24 Memorandum on the Substance of Discussion at a Department of State-Joint Chiefs of Staff Meeting, April 18, 1951, FRUS 1951, Vol.7, p.355.

25 Ibid, p.358.

26 Ibid, p.361.

27 The Commander in Chief, Far East (Ridgway) to the Joint Chiefs of Staff, April 27, 1951, FRUS 1951, Vol.7, p. 386.

28 Schnabel and Watson, The Joint Chiefs of Staff and National Policy, Vol.3, Part 1, p.483. 
of the other countries and the right to use facilities and bases controlled by them. ${ }^{29}$ It seemed obvious to the JCS and Ridgway that strikes on mainland China or the Soviet Far East would precipitate an expansion of the war, something that required the use of European bases to strike at the USSR. The directive to Ridgway, as Dingman rightly argued, gave him 'qualified authority to launch atomic strikes in retaliation for a major air attack originating beyond the Korean peninsula, yet the knowledge of what the consequences would be again created a situation that predicated non-use. ${ }^{130}$

The JCS re-stated their orders on May 1, laying out, in unequivocal terms, that under normal circumstances Ridgway had no authority to attack Chinese or Soviet territory. ${ }^{31}$ Nor was he to allow his armies to advance beyond what were known as the Kansas and Wyoming lines situated just beyond the 38th parallel. These two defensive lines, running from coast to coast across the peninsula, became heavily entrenched and fortified as the stalemate continued. ${ }^{32}$ Furthermore, in the event of massed air attacks from beyond Korea, the orders of April 28 were qualified by notification that Ridgway should inform the JCS of all facts pertaining to an attack and await approval before launching retaliatory strikes. ${ }^{33}$ With nuclear weapons now in deployment range of Korea and Ridgway in possession of strict orders regarding the extent of his retaliatory powers, the JCS were clearly making sure that, if the decision were taken to launch an atomic strike, the chain of command would function as intended.

As orders were flowing to Ridgway, the Joint House-Senate Committee on the MacArthur affair was beginning two long months of inquiry in Washington. The hearings took place in front of many familiar figures: Brewster, Flanders, Hickenlooper, Knowland, McMahon, Morse, and Wiley. During the hearings senior figures such as Bradley contended that MacArthur's belligerent actions — such as demanding the use of Nationalist Chinese forces and the atomic bomb-would have caused an expansion of the war and engaged too much US

29 The Joint Chiefs of Staff to the Commander in Chief, Far East (Ridgway), April 28, 1951, FRUS 1951, Vol.7, p.386.

30 Dingman, 'Atomic Diplomacy', p. 76.

31 The Joint Chiefs of Staff to the Commander in Chief, Far East (Ridgway), May 1, 1951, FRUS 1951, Vol.7, p.395.

32 Hermes, Truce Tent and Fighting Front, pp.73-76.

33 The Joint Chiefs of Staff to the Commander in Chief, Far East (Ridgway), May 1, 1951, FRUS 1951, Vol.7, p.396. 
power in an area of limited strategic importance. ${ }^{34}$ Some members of the investigating committee were also part of the JCAE and were aware of the bomb transfer to Guam. The potential for attacks on the officials testifying on behalf of the administration was doubtless coloured by the secret knowledge that Truman had readied his ultimate weapon.

At the same time as the hearings were taking place, the United States attempted to subtly inform China that the atomic option was still on the table. The State Department dispatched Charles Burton Marshall to Asia in order to find ways of delivering a covert message to the Chinese leadership. Marshall was kept in the dark regarding the nuclear deployment, but nonetheless, his language was, to those looking out for hints as to American intentions, brutally frank. ${ }^{35}$ He explained to intermediaries that the United States did not seek World War III. If, however, the situation became dire, America would exhibit 'no disposition to show mercy or consideration to any nation which had helped our adversary. ${ }^{16}$ Furthermore, 'If China were caught in the camp of our adversary at the outbreak of a world war it would have to suffer the consequences to the bitter end. ${ }^{37}$ According to Marshall, such a war would set Chinese progress back by one hundred years. ${ }^{38}$ Nitze recalled that Marshall managed to make indirect contact with no less a figure than Zhou Enlai. ${ }^{39}$ Dingman asserted, and circumstantial evidence backs this up, that Marshall's mission successfully hinted to the Chinese that the US might be willing to go farther than it had, but that this subtle, covert transfer of information did not constitute an overt atomic threat. ${ }^{40}$ The threat was covert, but manifestly there: anyone studying the words of Marshall would be immediately mindful of US atomic supremacy.

The Marshall communications represented another effort to gain leverage from the atomic arsenal short of overt threats of use. Timed as they were, it can be argued that they could have contributed to the PRC's willingness to begin serious peace negotiations in July. Even more importantly for the purposes of this study, they demonstrate that the Truman administration was learning from its previous attempts to use the atom bomb as a coercive or diplomatic tool. Rather than aggressively touting the potential for use, actions were subtle and

34 Schnabel \& Watson, The Joint Chiefs of Staff and National Policy, Vol.3, Part 1, p.554.

35 Dingman, 'Atomic Diplomacy', p.76.

36 Memorandum of Conversation, by Charles Burton Marshall of the Policy Planning Staff, May 9, 1951, FRUS 1951, Vol.7, p.1659.

37 Ibid.

38 Ibid.

39 Nitze, From Hiroshima to Glasnost, p.112.

40 Dingman, 'Atomic Diplomacy', pp.76-77 
nuanced, anticipating the doctrine of deterrence that would evolve during the Cold War.

Did Washington engage in a 'flirtation with MacArthurism', in the words of John Lewis Gaddis, in May with the approval of another significant policy paper, NSC-48/5? ?11 $^{41}$ This paper was an endorsement of the limited war policy that also stressed strong measures in the event of increased Chinese pressure in other parts of Asia. Many of the ideas contained within NSC48/5 were strikingly like MacArthur's, such as attacking mainland China and bringing Nationalist forces into the fight. However, the paper asserted the primacy of a negotiated settlement and an avoidance of expanded war. ${ }^{42}$ In relation to the possibility of a Soviet attack on Western Europe, the key position of allies was stressed. This was a vital point for, as Gaddis stated, NSC-48/5 did not adopt the MacArthurian stance that Asia should be the primary battleground with communism. ${ }^{43}$

Non-use, as it related to the Korean situation, continued to resonate, even after the dismissal of MacArthur. At a major conference of staff officers concerned with atomic weapons development, the Army wrestled with how the atomic bomb could be deployed. The pervasive influence of the emerging caste of 'defence intellectuals' can be detected in the transcripts. Dr. Ellis Johnston, one of the authors of December 1950 ORO report that provided MacArthur with so much analysis, received high praise. The officers around the conference table stated that:

If the Army is able to use the atomic bomb tactically in reasonable numbers in support of its operations, it can lick anybody and that is the opinion of a civilian [Johnston] who has been working for us for a couple of years now and who has seen the operations in Korea. ${ }^{44}$

Furthermore, despite the fact that 'the scientist' as an idealised figure was seen as deploring the use of the atomic bomb against civilians—-for example, Oppenheimer and his February article in The Bulletin — he was also positioned by the Army as 'anxious to support the Army, Navy, and Air Force in the tactical use of the atomic bomb, and that is one of the greatest supports and boosts that we have had. ${ }^{145}$ Here was a clear indication of civilian scientists directly influencing

41 Gaddis, Strategies of Containment, p.123.

42 NSC-48/5, 'A Report to the National Security Council by the Executive Secretary on United States Objectives, Policies and Courses of Action in Asia', May 17, 1951, DNSA, pp.4-5, 7.

43 Gaddis, Strategies of Containment, p.123.

44 'Probable Effects of Atomic Weapons Developments Upon the Structure of Army Operations', Department of the Army, Office of the Adjutant General, May 15, 1951, RG319, NARA, p.27.

45 Ibid. 
the military position on use or non-use.

Transcripts such as this illustrate the ongoing conflict between the idea that the atomic bomb should somehow be usable in a situation such as Korea and the notion that even tactical use represented something wholly different from any conventional weapon. As secondary figures in the armed forces were vigorously debating how to use the weapons, their superiors were wrestling with the realities of political necessity, public opinion, foreign relations, and moral uncertainty. The gradually dawning understanding that strategic use of nuclear weapons could easily tip the balance in favour of a global war drove the desire to find some tactical use for the weapons in which the United States had invested so much time, money, and expectation.

By June 1951 major Chinese offensives had been bloodily repulsed and UN forces had established a line of resistance just north of the $38^{\text {th }}$ parallel. This remained the front line for the next two years as armistice negotiations ground on. The United States could take stock of what it had achieved and analyse the situation in a calmer manner, unhurried by the constant seesaw of success and disaster. By late June 1951, the nuclear-equipped B-29s were redeployed to the US from Guam and the likelihood of nuclear use decreased dramatically. ${ }^{46}$

The period when atomic bombs were deployed to Guam saw a massive swing in the views of insiders privy to the decision making process. While fear that a huge communist intervention was about to precipitate global war opened the period, by the end fears had dramatically subsided. In addition to the step of deploying bombs overseas, there were also considered attempts to make use of the arsenal in a more subtle way, typified by Charles Burton Marshall's efforts to pass word of American retaliatory potential to the Chinese.

\section{OUTSIDERS}

During the April-June 1951 period, the influence of 'outsiders' was demonstrably less than in previous months. The administration had learned well the lessons of December and kept its nuclear decision-making as secretive as possible. Furthermore, it is informative to note that, unlike the influence exerted on the US by foreign nations during the December debacle,

46 Dingman, 'Atomic Diplomacy', p.78. 
key allies — especially the UK-began to be influenced by the US position.

\section{Congressional Opinion}

As the fallout from the April firing of MacArthur continued to affect debate in the United States, some in Congress wanted new weapons pressed into service in Korea. Congressman Alfred A. Gore (D-TN) submitted a plea that exactly replicated the views of MacArthur. He asked the President to authorise the use of 'cataclysmic' radioactive poisons to 'dehumanise' a belt of territory stretching across the Korean peninsula. ${ }^{47}$ Gore was a member of the House Appropriations Sub-committee, handling funds for the AEC and thus he was, according to the Washington Post, in a 'position to know about atomic developments. ${ }^{148}$

Whilst the administration, Pentagon, and AEC all declined to comment on Gore's suggestion that radioactive materials could be used to create a barrier across Korea, his comments provoked a response from Brien McMahon. The 'Atomic Senator' questioned the practicality of Gore's proposal, although he conceded that such methods might have shortterm applications. ${ }^{49}$ Gore shot back saying that 'some people may consider this idea crazy, just as other people think it crazy to keep swapping American lives for Chinese lives. ${ }^{150}$ The radioactive belt idea would not die away. Even into May the concept appeared in the media, with nationally known 'muckraking' journalist Drew Pearson gushingly describing it as 'revolutionary'. ${ }^{51}$

In the Senate, supporters of MacArthur were pushing for expanded action. Herman Welker (R-ID) advocated bombing and destroying bases within China, all the while disingenuously claiming that MacArthur had been firmly against expanding the war. ${ }^{52}$ Welker also dredged up the by then familiar accusation that, without permission to attack in China or use all the resources available in the US arsenal-by which he meant the atom bombAmerican boys were being forced to fight with one hand tied behind their backs. ${ }^{53}$

The administration position was once more defended by McMahon. He argued that it

47 Frank Carey, 'Radioactive Zone Across Korea Urged', Washington Post, April 17, 1951, p.7. Gore was, somewhat ironically, father of future Vice President and environmental campaigner Al Gore. 48 Ibid.

49 NA, 'Atomic Belt Plan Held Not Feasible', New York Times, April 18, 1951, p.16.

50 Ibid.

51 Drew Pearson, 'The Washington Merry-Go-Round', Washington Post, May 19, 1951, p.B13.

52 Herman Welker, CRS, 82/1, Vol.97, Part 3, April 24, 1951, p.4259.

53 Ibid, p.4257. 
was not within the purview of MacArthur to comment on, or to make calls for a radical change to, atomic policy. Alluding to the spectre of a destructive global war, he stated:

we have not come to the point where any one man can make a speech and in it can enunciate a policy which may result in the destruction of $150,000,000$ people, without having their representatives who serve in the Senate of the United States rise and make comment on those proposals. ${ }^{54}$

McMahon's prediction of the entire American population of $150,000,000$ people being wiped out may have been melodramatic, but his remarks underlined the point that policy could not, and should not, be decided by a single military man. He was also one of the few people outside of Truman's inner circle to know that the A-bombs were now on Guam.

Congressman Robert L. Sikes (D-FL) - in the incongruous setting of a road dedicating ceremony at Eglin Air Force Base in Florida - urged immediate use of the atom bomb in Korea in order to prevent an 'endless war'. ${ }^{55} \mathrm{He}$ also spoke in favour of 'other new and powerful weapons which will have a destructive and demoralizing effect on the enemy. ${ }^{156}$

An inkling of what these amazing new weapons might be comes from a minor media controversy surrounding comments by Congressman Overton Brooks in late May. Brooks said that the United States had perfected atomic weapons that could be shot from an artillery piece, positioning such weapons as something that should be used against the enemy in Korea. ${ }^{57} \mathrm{He}$ went on to say that 'the use of atomic shells in Korea will shorten the war. It will save the lives of thousands of our soldiers, sailors, and airmen, and will relieve the strain upon our people at home..$^{158}$

Brooks' comments on tactical atomic artillery were premature, but not unfounded. General Collins, George Marshall, Vannevar Bush and Secretary of the Army Frank Pace had all obliquely referred to the potential for such devices, even though atomic artillery shells were far from being ready to deploy. ${ }^{59}$ Indeed, they were not even properly tested until the UpshotKnothole series of nuclear blasts in Nevada in early $1953 .{ }^{60}$ Nevertheless, the prospect of a new

54 Brien McMahon, CRS, 82/1, Vol.97, Part 3, April 24, 1951, p.4258.

55 NA, 'Urges US Use A-Bomb, Other New Weapons', Chicago Daily Tribune, May 13, 1951, p.3.

56 Ibid.

57 NA, 'US Atom Shells Declared Ready', New York Times, May 24, 1951, p.24.; N/A, 'Atom Blasting Artillery Shell Called Ready', Washington Post, May 24, 1951, p.3.; Lloyd Norman, 'Urges US Use Atomic Shells to Shorten War', Chicago Daily Tribune, May 24, 1951, p.8.

58 NA, 'US Atom Shells Declared Ready', p.24.

59 Anders (ed.), Forging the Atomic Shield, p.151.

60 Ibid, p.239. 
tactical 'wonder weapon' generated a great deal of speculation in the press, and clearly showed that the media were enthusiastic about the use of the A-bomb in Korea. The tactical debate adds another layer to any analysis of non-use. When the distinction between tactical and strategic use began to enter into the popular consciousness, it would force the administration to explain not only why they were not using bombs against Chinese cities, but also why they were not using tactical weapons against enemy divisions in Korea.

\section{Foreign Relations}

'Outsiders' exerted less of an influence on the administration than they did in December of 1950, as the Truman administration became more skilled in the nuances of atomic diplomacy. The dismissal of MacArthur could be taken as exemplary of a decision that, in part, was shaped by an awareness of the effect of his statements and actions on world opinion. The same could be said, but in a sense conversely, of the careful and secretive way atomic weapons were deployed to Guam.

In respect of the former, on April 7 Prime Minister Jawarhalal Nehru of India-who had, in early December, been highly critical of MacArthur and the threat to peace his actions posed-had dispatched one of his diplomats in Washington to consult with Dean Rusk. This related to reports of both a Sino-Soviet build-up and the possibility of MacArthur being given increased powers to deal with the threat. Rusk confirmed that there were reports of significant Sino-Soviet military movements but that they were unsubstantiated. He also assured the Indian representative that MacArthur had not received permission to start bombing Manchuria. ${ }^{61}$ Foreign powers were fearful of MacArthur. It was felt that his immense standing with the American people might allow him to use his popularity to appeal directly to the public for even more destructive action in Korea. ${ }^{62}$ There was a great sense of relief in Europe and Asia when he was removed from command. Conversely, no foreign governments made representations to Washington about the deployment of atomic weapons on Guam.

The departure of MacArthur caused delight amongst some nations and brought clarifications from the State Department. Sir Benegal Rau, Indian representative at the UN,

61 Memorandum of Conversation, by the Acting Officer in Charge of India-Nepal-Ceylon Affairs (Weil), April 7, 1951, FRUS 1951, Vol.7, p.316-317.

62 Schnabel, Policy and Direction, p.288. 
opined that the removal of MacArthur and Truman's subsequent address to the nation had done much to improve the overall situation and the chances for a negotiated settlement. ${ }^{63}$ In conversation with Norman Makin, the Australian ambassador, Rusk pointed out that while it was being said in some quarters that the relief of MacArthur increased the chances of a peaceful end to the war, it did not change the fundamental US policy. ${ }^{64}$ The Assistant Secretary continued to stress that it seemed the Chinese were preparing for another offensive, despite the fact that it should be 'obvious' to them that they could gain a negotiated settlement on the basis of a cease-fire around the 38th parallel. ${ }^{65}$

Makin continued to be a voice for those concerned with the expansion of the war. In another meeting with Rusk, he brought up media reports from early April that stated MacArthur had been authorised to bomb Manchurian cities if a major Chinese air attack occurred. ${ }^{66}$ Rusk attempted to calm the situation: MacArthur had not been given authorisation to strike back and, of course, concerned governments would be consulted prior to retaliation against China. ${ }^{67}$ The assurances given by Rusk were disingenuous given the orders that were issued to Ridgway at the end of April. The US government was engaging in a balancing act between reassuring allies and preparing for the eventuality of a devastating Sino-Soviet air assault on Korea.

By the time of a joint US-UK meeting on April 12, MacArthur had already gone. Senior representatives from both nations convened to discuss the situation and the threat of Sino-Soviet action. ${ }^{68}$ The British delegates, as had been the case since the start of the conflict, expressed concerns about the imminence of World War III. The potential reaction to any supposed massed air attacks from the Chinese or Soviets, and the consequences arising from that reaction, was singled out for discussion. ${ }^{69}$

Behind the scenes, the PPS were clarifying how allies might be approached with

63 The United States Representative at the United Nations (Austin) to the Secretary of State, April 13, 1951, FRUS 1951, Vol.7, p.345.

64 Memorandum of Conversation, by the Assistant Secretary of State for Far Eastern Affairs (Rusk), April 14, 1951, FRUS 1951, Vol.7, p.347.

65 Ibid.

66 Memorandum of Conversation, by the Assistant Secretary of State for Far Eastern Affairs (Rusk), April 18, 1951, FRUS 1951, Vol.7, p.365.

67 Ibid, p.366.

68 Memorandum of Conversation, by the Director of the Policy Planning Staff (Nitze), April 12, 1951, FRUS 1951, Vol.7, p.338-342.

69 Ibid, p.339. 
sensitive atomic deployment information. Keeping the UK informed did not serve to restrict the freedom of action held by the President, the PPS suggested. ${ }^{70}$ Again, the peculiar characteristics of the atomic bomb, not least the lack of likelihood of it ever being used, were singled out for special attention:

While the atomic weapon is in some respects just another weapon in our national arsenal, its psychological impact is so great that use of it would doubtless precipitate general war, if war were not already under way. We are unlikely to use it, therefore, unless the vital security interests of the United States compel us to enter into general war with the Soviet Union. ${ }^{71}$

Despite the transfer of atomic bombs to Guam, all the covert threats, and governmental concerns, the policy of the United States had by this point crystallised. It had become recognised that nuclear weapons could only be used in a general war and that the use of the weapons outside of that circumstance would lead to general war. The weapon was more use as a deterrent to enemy action than it was as a weapon. Did this provide the basis for US-UK understanding?

Even in early May, US officials were still in conflict with their allies over the potential for a massed air attack. British intelligence estimates discounted the idea of huge Chinese aerial armadas striking UN forces and believed that should such an attack take place, it could only happen with the direct and substantial involvement of the USSR. ${ }^{72}$ Rumours that Ridgway had authority to retaliate without consultation should a major air assault take place were raised as a point of concern. ${ }^{73}$ What would have horrified the British government even more was that Ridgway was - until its withdrawal in late June-in a position to call upon the atomic strike force on Guam.

British Foreign Secretary Herbert Morrison's fears were eased by a personal note from Acheson. ${ }^{74}$ Morrison responded to his American counterpart on May 10 with a friendly, but firm, message. He emphasised once more the danger of bombing Chinese bases but additionally pointed out that the consequences of such an action would 'have to be faced and

\footnotetext{
70 Paper Prepared by Mr. Carlton Savage, Member of the Policy Planning Staff, 'Circumstances Under Which the United States Would Be at War With the Soviet Union: Use of Atomic Weapons', April 12, 1951, FRUS 1951, Vol.1, p.815.

71 Ibid.

72 The Ambassador in the United Kingdom (Gifford) to the Secretary of State, May 3, 1951, FRUS 1951, Vol.7, p.412.

73 Ibid, p.413.

74 Ibid, p.413-414. Morrison had only recently replaced Ernest Bevin as Foreign Secretary.
} 
shared by all of us. ${ }^{175}$

in the event of heavy (repeat heavy) air attacks from bases in China on United Nations forces in Korea, they [His Majesty's Government] will associate themselves with the policy of retaliatory action against these bases in order to prevent further attacks and to minimise casualties to United Nations forces in Korea. ${ }^{76}$

Whether they liked it or not, the British government had, by agreeing to the principle of retaliatory action against massed air attacks, given its permission for atomic strikes. Morrison was, however, careful to note that attacks coming from Soviet territory represented 'separate and even graver problems' and that such events were not covered by his comments on Chinese attacks. $^{77}$

Meanwhile, conservative Republican elements in the American press showed how out of touch they were with what was happening inside the administration by opening an attack on British diplomatic interference in atomic policy making. Holding to its familiar 'America first' stance, the Chicago Daily Tribune held Attlee's government responsible for the firing of MacArthur and American impotence in the face of Chinese provocation. MacArthur's dismissal, the Tribune claimed, was entirely at the bidding of the British government who were more concerned about Hong Kong and trade with China than the conduct of the Korean War. ${ }^{78}$ Pernicious British influence was also blamed for the notion that any attempts to bomb China would lead to World War III. ${ }^{79}$ And, in a total mis-characterisation of the December Truman-Attlee communiqué, it was stated that Truman had promised not to use the atomic bomb without first consulting the British. ${ }^{80}$ Following the Tribune's lead, Senator George W. Malone (R-NV) castigated Britain for recognising the PRC and charged it with thereby contributing to the forces killing American soldiers in Korea. ${ }^{81}$

On the other side of the Atlantic, perceived anti-American feeling caused Winston Churchill—who US commentators found it exceptionally difficult to characterise as being soft on communism—to speak out. The Tribune printed an approving piece on his May 19 speech

\footnotetext{
75 The British Embassy to the Department of State, May 10, 1951, FRUS 1951, Vol.7, p.428.

76 Ibid.

77 Ibid.

78 Arthur Sears Henning, 'British Molding of US Policy Stirs Up Storm', Chicago Daily Tribune, May 7, 1951, p.14.

79 Ibid.

80 Ibid.

81 Willard Edwards, 'Malone Assails Giving Britain A-Bomb Secrets', Chicago Daily Tribune, May 8, 1951, p.18.
} 
to Scottish Conservatives in Glasgow in which he warmly lauded the American contribution in Korea and vilified the 'pro-Chinese' attitudes of the Attlee government. ${ }^{82} \mathrm{He}$ also positioned the atom bomb as the force 'which alone gives us the hope of being able to form a front in Europe capable of deterring the Kremlin tyrants from further aggression there. ${ }^{183}$ Given the weakness of the Attlee government and the possibility of another general election (which took place in October), Churchill's anti-Labour tone is unsurprising.

Foreign nations were reported as being in a much more positive mood as battlefield conditions stabilised. As the first anniversary of the war approached, the Washington Post surveyed its correspondents around the globe to produce an image of world opinion. In general it was felt that the threat of World War III had reduced dramatically over the year. ${ }^{84}$ European and Asian nations expressed cautious optimism, with only Britain feeling that though the situation had improved in Korea, the world situation had worsened. ${ }^{85}$ The significance of this period in terms of external influence is not that allied governments, in particular the UK, exercised huge influence over decision making, more that foreign opinion was influenced into adopting the US position.

\section{Public Opinion}

The firing of MacArthur precipitated another outburst of public comment on the war in Korea and the possibility of general war, both of which included commentary on use or non-use of the A-bomb.

Support for MacArthur or support for Truman sharply divided correspondents. Some saw the General as eager to provoke the outbreak of a global war, while others viewed the prospect of war with relish and urged the atomic bombing of Moscow. ${ }^{86}$ One writer ended on a suitably apocalyptic note by saying 'We should ship our boys to Europe and prepare for Armageddon. ${ }^{87}$ A Chicagoan reacted violently to the MacArthur situation, commenting that he had polled his friends and found 'none of them willing to see that would-be American Hitler

82 NA, 'Anti-US Feeling Among Britons Stirs Churchill', Chicago Daily Tribune, May 19, 1951, p.3.

83 Ibid.

84 NA, 'Year of Korea Has Eased World War III Peril', Washington Post, June 17, 1951, p.B3.

85 Ibid.

86 Martha Ward Dudley, Letter, Washington Post, April 10, 1951, p.14; 'Realist', Letter, Washington Post, April 10, 1951, p.14.

87 'Realist', Washington Post, April 10, 1951, p.14. 
[MacArthur] plunge the United States into an atom-bomb war. ${ }^{188}$ The linkage between support for MacArthur and support for use of the A-bomb is clear, which leads to the conclusion that, at this point in time, public opinion was not aligned with what was happening within the administration.

On May 7 Truman gave an address-broadcast nationwide-to the Civil Defense Conference in Washington. In a carefully crafted text, written to alert but not excite, the President stressed that American foreign policy was always about preventing the outbreak of an atomic war. ${ }^{89}$ Prevention—which it is argued meant non-use of the A-bomb-was better, Truman said, than any proposed strategy of defence against atomic attack. ${ }^{90}$ Calls for an expansion of the Korean War through atomic strikes were criticised as being unable to prevent the further loss of American lives or bring the conflict to a speedy conclusion. ${ }^{91}$ The war in Korea should remain limited, Truman stressed, because another global war would be incredibly destructive: 'By fighting on a limited scale now, we may be able to prevent a third world war later on. ${ }^{12}$ The thrust of Truman's position was that decisions on use or non-use of the Abomb were firmly in the hands of the administration and, furthermore, they could be trusted to make the right decision.

Truman found his speech roundly, but not unexpectedly, condemned by a Chicago Daily Tribune editorial. The President was attacked for inviting atomic attack on America by his June 1950 decision to intervene in Korea in addition to lacking an understanding of the Russians. ${ }^{93}$ The paper stopped just shy of calling Truman a liar, but stated that 'Mr. Truman's falsehoods and fallacies will no longer work. The country has been educated on the Korean War beyond his power to bamboozle anybody. ${ }^{94}$ The UN and Europeans were also criticised: the UN was a failure and Western Europe needed American support to stave off the spectre of a Soviet invasion. ${ }^{95}$

Fighting back, the administration used the media to address public fear of atomic attack. Senior military figures such as USAF Chief of Operations General Roger M. Ramey

88 Clarence Ritchey, 'An American Hitler?', Letter, Chicago Daily Tribune, April 20, 1951, p.18.

89 Address at a Dinner of the Civil Defense Conference, May 7, PPHST, accessed on July 29, 2009.

90 Ibid.

91 Ibid.

92 Ibid.

93 NA, 'Mr Truman's Fears', Chicago Daily Tribune, May 9, 1951, p.16.

94 Ibid.

95 Ibid. 
propagandised about American atomic capability. In a widely syndicated magazine article, Ramey offered the optimistic analysis that, in the event of war, ninety percent of US atomic bombers would reach and strike their targets in the Soviet Union. ${ }^{96}$ 'In spite of all the scare stories about the vulnerability of American cities,' he confidently stated 'the fact remains that we can hit Russia easier than he can hit us. ${ }^{97}$ Ramey spoke the truth. Soviet capabilities were vastly over-emphasised in the minds of many Americans: the USAF had a far larger stockpile of bombs, and the means to deliver them, than the Soviet air arm. The Ramey article illuminates two related issues: that the possibility of use (on account of vast US atomic superiority) paradoxically led to non-use; and, that the administration was now taking steps to mould public opinion towards non-use. By stating that US vulnerability was over-rated and retaliatory capability substantial, Ramey made the case that the bomb need not be used at the present time and, unintentionally, strengthened the case for tactical use.

The possibility of an atomic attack within Korea received further attention when MacArthur sought to clarify his position on the weapon. His aide, General Courtney Whitney, stated to the press that the dismissed commander had 'studied the potentiality of atomic weapons' but once he had completed his study, he never actually recommended their use. ${ }^{98}$ Given MacArthur's requests throughout the war for access to atomic capability, this 'clarification' was disingenuous at best and an outright lie at worst. But it demonstrates MacArthur's by now acute sensitivity to the overall public mood, which wavered about an expanded war.

In the wake of Truman's May 7 Civil Defense speech, some Americans indeed expressed terror at the thought of a Soviet attack. Citizens such as Della Bennett of Washington wrote letters verging on the hysterical. 'The President has now convinced me,' she wrote:

As he spoke to the Civil Defense Conference, I could hear the explosion of the atom bomb in my front yard. I made up my mind that no matter how sensible the arguments on the other side might sound, I would not forget my vision of that moment. ${ }^{99}$

The terrified Ms. Bennett concluded '[M]y mind is paralyzed with terror. Atom bombs are still

96 NA, 'AirGen Ramey Says US Can Outbomb Reds', Washington Post, May 8, 1951, p.10.

97 Ibid.

98 NA, 'M'Arthur Never Ok'd Atom Bomb Use, Says Aide', Chicago Daily Tribune, May 13, 1951, p.3.

99 Della Bennett, 'Terrorism', Letter, Washington Post, May 14, 1951, p. 8. 
exploding in my ears. ${ }^{100}$ Conversely, some members of the public viewed the situation through an entirely different lens. One writer commented that the last thing that Stalin desired at this point in time was a general war with the United States and consequently, it was worthwhile taking the risk of expanding the war in to China. ${ }^{101}$ Once more, this demonstrates that public opinion was never settled on the issue of use or non-use.

Opinion polls taken during April, May, and June revealed a substantial majority of Americans supporting a continued presence in Korea. In May, seventy-three percent of respondents advocated carrying on the fight, up five percent on the previous month. Confidence about remaining in Korea dropped slightly in May, but remained at a substantial sixty-three percent. Over the same time period, however, a large minority of Americansforty-five percent in April and forty-two percent in early June-believed that the United States had made a mistake in getting involved in Korea. ${ }^{102}$

Even more illuminating was the drop in fear of global war sometime in the next five to ten years. When China entered the conflict, war fears peaked at an all time high. During the period when Truman sent atomic bombs to Guam, the fear of major war within five to ten years dropped substantially, to a little over seventy percent for war within ten years and around fifty-two percent for war within five years. ${ }^{103}$ All the more remarkable, then, is the jump in fear that war would come within the next two years: it shot up by over ten percent, up to forty-five percent of respondents. ${ }^{104}$

During the period of the Guam deployment, it is obvious from its efforts—such as the Truman's Civil Defense speech and the Ramey article — that the administration was aware of and took steps to modify—public opinion. Support for MacArthur and support for the Abomb were two issues that were conflated in the public consciousness. Yet, this does not marry with the position of the administration. The secretive steps taken by Truman to ready the atomic arsenal did not leak into the public domain, therefore lending weight to the perceived 'MacArthur equals use' position.

100 Ibid

101 Patrick J. Murphy, 'MacArthur's Risk', Letter, Washington Post, May 16, 1951, p.12.

102 Mueller, 'Trends in Popular Support for the Wars in Korea and Vietnam', p.360.

103 Mueller, 'Expectations of War During the Cold War', p.304.

104 Ibid. 


\section{CONCLUDING REMARKS}

The period from April to June 1951 demonstrated, more clearly than any other during the Korean War, the administration's evolving understanding of debates about, and reactions to, atomic weapons.

The move of complete atomic bombs beyond the borders of the United States was a hugely significant event. Intelligence information indicated — vaguely and with hesitation—-that the communist world might have been about to launch the long-expected major attack on the West. If the United States were to have any hope of standing against this offensive, they must be ready to use the 'ultimate weapon'. Within the higher echelons of the administration and the military, April represented the peak of expectation that major war could break out. The danger posed by a renewed Chinese offensive, possibly backed up by mass air assaults supported by Soviet forces, was too much for the US to ignore and led directly to the transfer of atomic weapons to Guam.

The dismissal of Douglas MacArthur was immensely damaging, both to Truman personally and to his administration. It created such a public outcry and so much political soulsearching that all other issues were hidden beneath a blanket of recrimination. But, as we have seen, this was immensely convenient for the administration at a time of tension. Even the JCAE—some members of which were hostile to the incumbent administration-kept the movement of A-bombs quiet.

The story does not end there however. The administration realised that these weapons could only be used under the most extreme circumstances. The concern, as it had been for many months, was to keep the Korean conflict limited in scope, geographically, in terms of weapons used, and in terms of the combatants involved. There was a desperate desire to keep the USSR from participating directly in the conflict. Challenging the boundaries of the war by using the A-bomb would have broken all the limits then in place.

In light of the extreme fear of major war, it is ironic that just weeks later the situation saw a remarkable decrease in long-term war-fear. The inability of the Chinese offensive to break the UN line and the non-appearance of massive, Soviet backed air forces, coupled with more serious talk about armistice negotiations, led to a precipitous drop-off in talk of expanded war. From the high point of concern about a worldwide conflagration, Truman and 
his colleagues now saw a future that was more hopeful and less clouded by the possibility of atomic explosions and massed Soviet air armies. Truman held back, this time, because the anticipated situation simply did not transpire. The atomic bombs were sent back to the US as it became apparent that the circumstances that had prompted their deployment had passed by. Tannenwald identified declining escalation risks as a factor leading to non-use, but passes over the Guam deployment period relatively swiftly, and failed to delve deeper into the overall picture of this time frame. ${ }^{105}$ This approach means that Tannenwald did not identify key instances of the administration's attempts to use the atomic threat as a deterrent and bargaining chip, specifically in the case of the Charles Burton Marshall communications.

Dingman succinctly analysed the influence of this period on the thinking of the Truman administration. 'Rather than making senior officials eager to employ them [the atomic bombs],' he says, 'it reinforced their reluctance to do so. ${ }^{106}$ He noted that Truman saw his action in sending nuclear-armed bombers to Guam as a one-off, an action instituted only because of the grave danger posed by a potential Sino-Soviet assault on the UN in Korea. ${ }^{107}$ Further, and expanding on Dingman's comments, it is clear that the administration had reached a position where it realised that the atomic bomb could not even be used in a situation where the gravest danger seemed to be present. A pre-emptive strike on massed air armadas might have seemed like a tempting option, but it was something that Truman realised could never happen without plunging the world into the darkness of another global war.

The President was only too aware of the horrors that might materialise if he gave the order to unleash the atom bombs. In a reflective, private memo written two years after the transfer of bombs to Guam, he mused on the terrible consequences that a decision to use them could have had. He was fully aware that to have any effect on the communist world, atom bombing needed to be widespread; 'To have been effective Peking, Shanghai, Canton, Mukden, Dairen, Vladivostok, and Central Siberia at Ulan-Ude on Lake Baikal would have had to be destroyed. It would have been a unilateral action by the USA. ${ }^{108}$ Truman knew that any such action would result in World War III and moreover, there were moral issues in play. He claimed that he could not have 'wiped out those great Chinese cities and have killed some 25,000,000

105 Tannenwald, The Nuclear Taboo, p.125, 128.

106 Dingman, 'Atomic Diplomacy', p.78.

107 Ibid.

108 Truman, Memorandum, April 24, 1954, in Ferrell (ed.), Off The Record, p.304. 
innocent women, children, and non-combatants. ${ }^{109}$ He reflected back on his order to bomb Hiroshima and Nagasaki, categorising those two cities as 'places devoted almost exclusively to war production'.110 That may have been a justification that scaled the heights of self-deception but regardless Korea, in his eyes, was a totally different situation, one where the use of atomic weapons was unjustified. The former president, with the perspective of years, concluded: 'I just could not make the order for a Third World War. I know I was right.'111 This amplifies Dingman's findings: The move of atomic bombs to Guam demonstrates just how terrifying Truman found the situation in April. In an effort to head off the world war that he so dreaded, he took the remarkable step of coming closer to use of the A-bomb than he had ever been since the end of World War II.

However, Truman's post-facto comments make for interesting reading, given that the possibility of use never wholly disappeared. They also show a certainty that was never really there at the time, highlighting a disconnect in Truman's private comments. While in some cases he was adamant that he would never, under any circumstances, order an atomic attack on account of developments in Korea, other statements seemingly give the lie to this notion. As Chapter Five will go on to demonstrate, under extreme stress, such a paradox in his thinking caused Truman to express much more violent, less tolerant tendencies, much as had happened on November 30, 1950.

In terms of shaping a 'doctrine' of non-use, it is vital to highlight the contribution of Matthew Ridgway. His assumption of command, first as senior field officer and then as supreme commander, helped to stabilise the military situation. Ridgway reinvigorated the battered UN forces after the crushing defeats at the hands of the CPVA. His charismatic leadership gave the tired soldiers, slogging through the mountains of Korea, a new sense of esprit de corps. When given overall command, he proved himself willing and able to recognise civilian authority and work within his remit as a soldier. Ridgway was not a man who took rash action, nor was he prone to flights of egotistical fancy such as those taken by his illustrious predecessor. He made an immense contribution to decreasing the chances of Korea expanding into major war and also into evolving the practice of non-use. Through wise tactical and 
strategic decisions, deference to the global policy coming out of Washington and an understanding of the wider situation, he made the UN position more tenable and at the same time lessened the need for wider action. This is not to say that he completely dismissed the potential for wider action. As the evidence shows, he was keen to have a contingency in place should the worst come to the worst. Unlike MacArthur, he did not see these contingencies as anything more than a backup in the event of disaster. For MacArthur, an expanded war against China had been a tacit aim. For Ridgway, attacks against China would be a last resort under extreme duress.

Ridgway demonstrates the key role of the individual in the overall play of events. It is tempting to speculate what would have taken place had MacArthur remained in overall command and had General Walker, Ridgway's predecessor, not died in December of 1950. A continued retreat to the sea and an ignominious escape to Japan may have been likely outcomes. In that situation, the temptation to unleash the atomic bombers to extract revenge may have been too much even for Truman. Truman and Ridgway illustrate the way in which key figures influenced events - Truman, as the chief executive who would have to make the ultimate decision, and Ridgway as the seasoned soldier who turned the situation on the battlefield around.

Despite the decision to transfer bombs close to a theatre of war-an action that had not been taken in six years of US possession of nuclear weapons - there was little to no public comment or outcry about the move. The Truman administration had learned the lessons of the previous year and kept the decision firmly under wraps. The civil defence address by Truman is a prime example of concern over public opinion. Clothed in the garb of a general comment on the state of American readiness, it offered the average American a concise view into Korean War policy. The key aim of the United States was to avoid provoking the outbreak of World War III, an outright dismissal of MacArthur and his notions of expanded war. As Casey noted 'Civil defense had always been a good way for the government to drive home the ominous nature of the Soviet menace on the one hand while stressing the horrible consequences that accompanied a world war on the other. ${ }^{112}$ This perceptive description of government use of civil defence is entirely appropriate for Truman's May 7 speech. By making 
a bold statement, the administration attempted to silence critics on the MacArthur dismissal, lay out their atomic weapons policy, and educate the public as to the awful nature of an expanded war stemming from the situation in Korea. On the opposite side, the Truman administration recognised that public opinion was of vital importance and hence took these measures to fight back against aggressive, pro-bomb views being expressed by members of Congress and the public.

Finally, there are extremely interesting changes to the position of the UK regarding the atomic weapon during this period. Britain had, in December 1950, been a world leader in seeking assurances from Truman that the A-bomb would not be used in Korea. Now, as the Morrison memo illustrates, the UK offered tacit agreement to nuclear action, should circumstances warrant it. This commitment was, without a doubt, heavily qualified. However, it does demonstrate that, unlike December 1950, the United States was moulding foreign opinion to its own ends, rather than vice versa. This interesting point, which once again highlights the fact that the potential for use never disappeared, is scarcely mentioned in the existing scholarship. It is highly pertinent to the argument of this thesis, as an example of an ongoing education in the subtleties of nuclear diplomacy on the part of the Truman administration.

The Korean War would now settle down to two years of protracted, painful armistice negotiations. During this period, men on both sides continued to die in the fighting that continually took place along the front line. The Truman administration was faced with an upcoming Presidential election and an increasing hostile public. And, despite the much improved situation, the atomic bomb did not disappear entirely from the debate. However, the most threatening part of the conflict was now over because, through numerous crises, Truman had managed to exercise restraint. But, the way in which the Truman administration handled nuclear issues for the next eighteen months owed much to the pattern established in the fraught months of spring and summer 1951. 


\section{Chapter 5: 'Unthinkable for Rational Men'}

The first year of the Korean War had been for all concerned, an unrelenting series of defeats, victories, and near disasters. As armistice negotiations began at Kaesong in July 1951, the conflict settled down into a static phase that replaced the constant war of movement. ${ }^{1}$ No longer a series of wide-ranging strikes and counter strikes, Korea became more akin to the Western Front of 1914-18, with troops digging in and hunkering down in trenches and bunkers that zig-zagged across the country.

It is important to note that discussions relating to the bomb did not disappear. On the US side, worries that the negotiations were an elaborate ruse to cover preparations for another Chinese offensive, allied to the desire to remain at a high level of preparedness, led to a series of practice atomic attacks on Chinese positions as the USAF attempted to formulate a doctrine of battlefield nuclear weapons use.

The existing historiography of nuclear non-use in Korea gives scant attention to this still significant period. Whereas Dingman offered a highly perceptive analysis of four case studies_covering June-July 1950, December 1950-January 1951, April 1951, and January-July 1953 - this thesis suggests that a broader interpretation of the entire war during the Truman administration, looking at the consistent way in which nuclear weapons and their potential were always a matter for debate at all levels, allows a more nuanced interpretation of American policy and the fundamental decision not to utilise nuclear weapons. This chapter shows that attempts to find uses for the A-bomb, and to create a protocol for use, were prevalent themes throughout the war, not simply during instances of heightened tension. It highlights the importance of looking beyond the most highly visible incidents, such as of December 1950 or April 1951, offering evidence that A-bomb thinking-and the ongoing 'education' of key figures and institutions - was a theme that ran through the entirety of the Truman administration experience of the Korean War.

1 It was found that Kaesong was too close to the front line and the negotiations would move to Panmunjom in October 1951. 


\section{INSIDERS}

By mid-1951, the concept of tactical atomic weapons had been enthusiastically grasped. Not only did these physically smaller A-bombs offer new possibilities for the war in Korea, they provoked planners into undertaking studies to formulate concrete plans for tactical usage in wartime.

\section{Hudson Harbor}

While the negotiations at Kaesong were beginning, the US political and military establishments were dealing with a range of forces pushing for their opinions on the A-bomb to be heard. For Ridgway, most troublesome was the dictatorial ROK President, Syngman Rhee. Rhee badgered the General to conduct wide ranging military action and stated that if 'Korea [were] ever to be united short of world war III it must be done now by mil[itary] means. $^{2}$ The ROK leader insisted that the Koreans wished re-unification at any cost and by taking part in the negotiations, all the UN would be doing was helping the communists and hastening the onset of World War III. Ridgway shot back that if a third world war was inevitable, then the UN could ill-afford to exhaust their resources in Korea. ${ }^{3}$ Rhee also asked why the US had not used the atomic bomb yet, causing an irritated Ridgway to respond that such action would only precipitate the major war Rhee seemed so keen to avoid. ${ }^{4}$

Just two weeks later, the Joint Strategic Survey Committee (JSSC) and the State Department outlined the circumstances under which the United States would engage in atomic warfare. The report appeared because of fears that the negotiations in Korea may have been a stalling tactic on the part of the communists, a delay allowing them to prepare for a destructive strike against American interests. Drawing together many threads from the discussions of the past year, the paper considered global war, domestic support, and foreign opinion. ${ }^{5}$ The report stressed that if the US were ever to use atomic weapons on the battlefield, then wide-ranging public support, foreign and domestic, was essential. ${ }^{6}$ Here was

2 The Ambassador in Korea (Muccio) to the Secretary of State, July 17, 1951, FRUS 1951, Vol.7, p.694.

3 Ibid, p.695.

4 Ibid.

5 Paper Prepared by the JSSC and Representatives of the Department of State, 'United States Position on Considerations Under Which the United States Will Accept War and on Atomic Warfare', August 3, 1951, FRUS 1951, Vol.1, pp.866-874. The JSSC was the senior advisory body reporting to the JCS.

6 Ibid, p.871. 
further recognition that the atomic issue was wholly different, demonstrating the evolving awareness-something that had begun early in the war-that public support was of critical importance.

August saw a flurry of reports and actions related to nuclear issues, all stemming from the same concerns that had provoked the JSSC and the State Department. NSC-114/1, issued on August 8, estimated that the Soviet atomic stockpile was growing at a far greater rate than previously believed. The report writers thought Korea demonstrated Soviet willingness to run the risk of global war in order to achieve its aims and, consequently, the danger to US national security was greater than at any time since before the outbreak of fighting in Korea.

As the shaky peace negotiations continued, there was brief consideration that atomic weapons might be used to break the stalemate. The JCS had asked the Joint Strategic Plans Committee (JSPC) to look at the tactical possibilities of the atomic bomb. ${ }^{8}$ On August 11, the JSPC returned with the conclusion that tactical use of the bomb might be appropriate to stave off an impending military disaster, but that thought must given to the dangers of expanded war.' They recognised an urgent need for the development of plans and procedures for tactical atomic strikes against targets in Korea and advocated a series of simulated attacks. ${ }^{10}$ Recommending this course of action, the JCS did not believe that Presidential approval was required. However, Secretary of Defense Marshall disagreed and approached Truman for permission to carry out the missions. ${ }^{11}$ This shows a certain fracturing of opinion between the JCS and the politicians. Marshall, with his decades of military service and the authority of his office, effectively 'pulled rank' on the military. It demonstrates an understanding on Marshall's part that issues surrounding the atomic bomb could never be considered on purely military grounds: they must be considered on political grounds.

From late September until early October, aircraft carried out a series of simulated atomic attacks on targets in Korea. The exercise, codenamed Hudson Harbor, did not use any nuclear weapons-by this stage the bombs that been sent to Guam in April had been shipped

7 NSC-114/1, 'Status and Timings of Current US Programs for National Security', FRUS 1951, Vol.1, p.129, 132.

8 Schnabel and Watson, The Joint Chiefs of Staff and National Policy, Vol.3, Part 2, p.613.

9 Ibid.

10 Ibid.

11 Ibid, p.614. 
back to the United States and no weapons remained within transport range of Korea. ${ }^{12}$ However, the four operations that made up the programme took place under conditions that simulated, as closely as possible, actual nuclear procedures. ${ }^{13}$ Hudson Harbor, despite its seemingly provocative nature, went largely un-noticed by outside observers. It did, however, show an evolution of US planning and the desire to formulate concrete protocols based on practice, rather than theory. At the end of the exercise, senior air commanders concluded there had been a consistent failure to establish that there were worthwhile atomic targets in Korea. ${ }^{14}$ The outcomes of Hudson Harbour demonstrate that the debate over the availability of targets in Korea could not be settled, even with simulated atomic strikes. Contrasted with the December 1950 ORO report, it indicates that even the 'best and brightest' within the military and scientific communities were at odds when it came to deciding if targets existed.

Hudson Harbor illustrated the ongoing low level of military preparedness regarding delivery of atomic bombs against Korean targets and a continued reluctance, on the part of many senior military officials, to see any worthwhile targets on the peninsula. Dingman gave no consideration to the operation in his otherwise perceptive work and Tannenwald relegated mention of it to the tail end of a paragraph on the difficulty, both physically and psychologically, of finding suitable targets in Korea. However, Tannenwald argued that it was inhibitions regarding the use of atomic weapons in a war situation that contributed to the apparent lack of readiness. ${ }^{15}$ Hudson Harbor is vitally important in examining the overall pattern of non-use because it demonstrates that even the atomically aggressive USAF, despite undertaking physical measures to study use, struggled to find ways to utilise the A-bomb in Korea. The operation showcases the tension between practical action, intellectual theorising, use, and non-use, offering a model where so many issues that have been discussed in the existing scholarship merge.

\section{Tactical Applications}

As the discussions that initiated Hudson Harbor were taking place, theoretical deliberations over the tactical role of nuclear weapons intensified. On August $15 \mathrm{~J}$. Kenneth

12 Ibid.

13 Crane, American Airpower Strategy, p.71.

14 Ibid.

15 Tannenwald, The Nuclear Taboo, pp.134-135. 
Mansfield, Chief of Special Projects reporting to the JCAE, commented to Brien McMahon that 'tactical atomic weapons hold forth the promise of a revolution in land war which can be compared to the revolution in air war brought about by the Hiroshima and Nagasaki bombs. ${ }^{16}$ Like the discussions that initiated Hudson Harbor, Mansfield argued that American tactical atomic planning had been slow and too small-scale. ${ }^{17}$ He stressed that 'the actual development of tactical atomic weapons themselves has been more rapid than the development of our thinking on how to use them. ${ }^{18}$ Here in microcosm was the situation-provoked by the inability to use the bomb strategically in Korea—with A-bomb thinking: the technology was most certainly there and advancing at a perilous rate, but the philosophy lagged far behind.

Frank Pace was informed on November 7 that atomic artillery would be available by the spring of $1952 .{ }^{19}$ The notion of cannons and howitzers that shot small A-bombs at an advancing enemy thrilled politicians, soldiers, and the public. However, Gordon Dean had noted in August that he did not expect such artillery to be available until the autumn of 1952 at the earliest, mainly due to difficulties in producing specialist cannons. ${ }^{20}$ Dean had to explain all of this to Truman, who had been convinced by other sources that such firepower was almost ready to be deployed to Korea. ${ }^{21}$

Tactical weapons had indeed caught the imagination of the media and public. From mid-1951 onwards there was a barrage of stories regarding amazing new applications for atomic arms. Atomic artillery shells and bombs that could be dropped by fighter planes were lauded in the press by Secretary of the Air Force Thomas K. Finletter and General Vandenberg. ${ }^{22}$ Such was the media enthusiasm for these developments that Marshall's successor as Secretary of Defense, Robert A. Lovett, had to combat such eagerness at his first official press conference. Lovett acknowledged the great strides made in atomic weapons, but that none of the amazing new developments were yet ready for use on the battlefield. ${ }^{23}$

\footnotetext{
16 Memorandum by the Chief of Special Projects, Joint Congressional Committee on Atomic Energy (Mansfield), to the Chairman of Committee (McMahon), August 15, 1951, FRUS 1951, Vol.1, pp.158-163.

17 Ibid, p.159.

18 Ibid, p.160.

19 Memorandum for Mr. Pace from Robert LeBaron, Subject: Atomic Weapons, November 7, 1951, DNSA, p.3.

20 Dean, diary, August 31, 1951, in Anders (ed.), Forging the Atomic Shield, p.161.

21 Ibid.

22 NA, 'Finletter Depicts New Atomic Arms', New York Times, August 26, 1951, p.17.; Hanson W. Baldwin, 'New Air Theory Shaped', New York Times, September 11, 1951, p.7.

23 John G. Norris, 'Lovett Puts New Weapons Talk In Focus', Washington Post, September 26, 1951, p.3. Lovett
} 
Lovett's comments, and similarly down-to-earth analysis by Marquis Childs of the Washington Post, failed to dampen the rampant enthusiasm. ${ }^{24}$ General Collins added to the clamour in December with comments that atomic artillery had been tested and would be ready in the 'not too distant future. ${ }^{125}$ In May 1952, Pace, speaking in the rather incongruous atmosphere of the National Wool Manufacturers Association conference, revealed further developments in the field of atomic guns. ${ }^{26}$ Finally, in July, Collins sent a mixed message, stating that UN forces in Korea now had the capacity to utilise tactical atomic weapons, then modified his remarks, noting that he thought that even a small tactical A-bomb was impractical for use in Korea and that there were no current plans to actually make use of such weapons. ${ }^{27}$

The State Department and CIA worried that World War III might be on the horizon or that the USSR might be planning a surprise atomic attack on the United States. Advisers, such as Soviet expert Charles Bohlen, outlined a pessimistic scenario where an expanded war-triggered by miscalculations on the part of the United States—was still a very real possibility. ${ }^{28}$ Yet, three months later, Bohlen wondered if, given the USSR was aware that a thrust into Germany would result in US atomic retaliation, whether there were enough explicit sanctions of a similar kind directed towards China ${ }^{29}$ The CIA thought that, lacking a credible atomic strike force, the USSR might adopt clandestine methods to hit America with A-bombs. The agency speculated that this could be achieved by disguising bombers as civil airliners or launching missiles from converted merchant vessels. ${ }^{30}$

NSC-118/1, issued at the end of 1951, mused on the diminished, but still present, danger of general war and the conduct of armistice negotiations. In closing, the report worried that if armistice discussions went on for too long, demands for a clear-cut military

had replaced Marshall as Secretary on September 17.

24 Marquis Childs, 'Atomic Weapons: A Dose of Over-Salesmanship?', Washington Post, October 10, 1951, p.13.

25 John G. Norris, 'Atomic Artillery Developed and Tested, Gen. Collins Says', Washington Post, December 7, 1951, p.8

26 NA, 'Pace Reveals Details of Atomic Gun', Washington Post, May 9, 1952, p.10.

27 NA, 'Atomic Weapons Ready In Korea', New York Times, July 9, 1952, p.3; NA, 'Collins Says Korea Forces Are Capable of Using A-Arms', Washington Post, July 9, 1952, p.12.

28 Memorandum by the Counsellor (Bohlen), August 22, 1951, FRUS 1951, Vol.1, pp.163-166; Memorandum by Mr. Henry Koch, Member of the Policy Planning Staff, to the Deputy Director of the Staff (Ferguson), August 24, 1951, FRUS 1951, Vol.1, p.167.

29 Memorandum of Conversation, by Walter N. Treumann of the office of Northeast Asian Affairs, Summary of JCS Meeting, November 26, 1951, FRUS 1951, Vol.7, p.1179.

30 NIE-31 'Soviet Capabilities for Clandestine Attack Against the US with Weapons of Mass Destruction and the Vulnerability of the US to Such Attack (mid-1951 to mid-1952)', September 4, 1951, DNSA, p.1-2. 
victory might cause domestic problems. ${ }^{31}$ Calls for victory, by whatever means possible, 'might seriously divide the American people, hurt US prestige throughout the world, and endanger the basic strategic position of the United States. ${ }^{132}$

\section{Into 1952}

As the war entered its third calendar year, Ridgway expressed concerns about how the UN forces could, and should, react in the event of a hypothetical post-armistice communist offensive. Truman, he had concluded, would not authorise the use of atomic weapons against China and as such, his command lacked the capability to cause lasting damage to the warmaking potential of the PRC. In his view 'the retributive potentiality of UN military power against Red China would be noneffective unless the full results of precipitating World War 3 were to be accepted, and the use of atomic weapons auth[orised]. ${ }^{133}$ Ridgway was reacting to correspondence from the JCS which stated that communist forces should realise that a resumption of offensive manoeuvres would 'bring upon China [the] full retribution which the United States and her Allies deem militarily desirable. ${ }^{134}$ The General was of the opinion that the UN forces were not in a position to carry out any such retributive action. It is, however, instructive to note the difference between Ridgway and his predecessor. Unlike MacArthur, Ridgway understood the difference between the atomic bomb and conventional weapons. His reluctance to use the bomb stemmed from an intelligent pragmatism. He foresaw only to well that if the weapons had to be used, then those who used them must accept responsibility for the consequences.

The enthusiasm for tactical atomic weapons continued unabated, with Lovett and Vandenberg positioning them as an efficient and economical means of waging war, giving a major advantage to those able to make best use of them. ${ }^{35}$ With the failure to find any use for the A-bomb as a strategic instrument, it is unsurprising that those who had overseen the vast sums of money spent on the atomic programme wished to find some way to justify the

31 NSC-118/1, 'United States Objectives and Courses of Action in Korea', December 14, 1951, DNSA, p.13.

32 Ibid.

33 The Commander in Chief, United Nations Command (Ridgway) to the Department of the Army, January 7, 1952, FRUS 1952-1954, Vol.15, Pt.1, p.11

34 The Joint Chiefs of Staff to the Commander in Chief, Far East (Ridgway), December 19, 1951, FRUS 1951, Vol.7, p.1378.

35 Memorandum for the President, Discussions of the Special Committee of the National Security Council on Atomic Energy, January 17, 1952, DNSA, pp.2-3, 5. 
expenditure. In many ways, this can be related to the influence that Korea had upon US defence planning and expenditure. As Marc Trachtenberg pointed out, during 1950 and 1951, officials saw a 'window of opportunity for the USSR, where US military preparedness, even backed by the limited atomic stockpile, was not enough to deter a potential pre-emptive strike by the Soviets. ${ }^{136}$ Korea had demonstrated, at least to US eyes, that the communists thought themselves in a strong enough position to risk general war. ${ }^{37}$ The massive appropriations sought, and gained by Truman to finance the build-up envisaged in NSC-68, had to be justified to Congress and the public in some manner.

Vandenberg was once more at the forefront of promoting aggressive strategies to intimidate the Chinese. His boldest proposal in early 1952 was to fly B-29s towards Shanghai, making sure the Chinese were well aware of their presence. ${ }^{38}$ The bombers would then veer away down the coast at the last minute in an attempt to frighten the communists into thinking that the US was seriously considering raids against Chinese cities. ${ }^{39}$ Bohlen, with marked understatement, thought that 'the reaction in the free world would be poor' and that 'A show of force might boomerang. ${ }^{40}$ December 1950 had driven home the importance of foreign opinion and it was now something that many officials were well attuned to. Even Vandenberg, not normally noted for his attention to world opinion, later stated that if atomic strikes were launched from bases in Okinawa, this 'might be unpopular with the Japanese. ${ }^{14}$ In July, Truman demonstrated the potential for use was still on his mind and approved the transfer of twelve non-nuclear bomb components for storage aboard the aircraft carrier Kearsarge and then, on the $18^{\text {th }}$ of the month, sanctioned the transfer of more components for storage at 'overseas bases. ${ }^{142}$

At the same time, Truman released his frustrations in the pages of his diary. He railed against the iniquities of the communists and their lack of morals and honour. Alone with his

36 Trachtenberg, 'A "Wasting Asset"', p.16.

37 Ibid, p.17.

38 Memorandum of the Substance of Discussion at a Department of State-Joint Chiefs of Staff Meeting, February 6, 1952, FRUS 1952-1954, Vol.15, Pt.1, p.39.

39 Ibid.

40 Ibid, pp.39-40.

41 Memorandum of the Substance of Discussion at a Department of State-Joint Chiefs of Staff Meeting, April 2, 1952, FRUS 1952-1954, Vol.14, Pt.2, pp.1225-1226.

42 James S. Lay to The Secretary of Defense and the Chairman, Atomic Energy Commission, letter, July 3 , 1952, DNSA; Memorandum for the President, July 18, 1952, DNSA; James S. Lay to The Secretary of Defense and the Chairman, Atomic Energy Commission, letter, July 22, 1952, DNSA. 
thoughts, he threatened China and the USSR with atomic retribution: 'Now do you want an end to hostilities in Korea or do you want China and Siberia destroyed? ${ }^{143}$ These remarks were the venting of anger by a tired, frustrated man who, suffering assaults from all sides, found a way to dissipate his rage without causing a scene. This provides yet another stark illustration of the mental situation Truman found himself in. He continued to cognitively procrastinate, vacillating between fear over the consequences of atomic use and threats to unleash the weapon.

\section{Exit Ridgway, Enter Clark}

On May 12, Ridgway left his Asian commands to take up the position of Supreme Allied Commander, Europe, a NATO role recently vacated by Dwight D. Eisenhower, who ended his military career to run for President. Ridgway was replaced by General Mark W. Clark, who, as the months progressed, came up with a variety of schemes aimed at giving UN forces the upper hand as the negotiations at Panmunjom dragged on. Convinced by his experiences during post-World War II negotiations with communists in Austria that force was the only thing they understood, he stepped up the air war against the DPRK, organising massive bombing raids against dams and power stations, causing a two week blackout across the north. ${ }^{44}$ By the end of August he had also ordered three huge attacks on Pyongyang, as well as ordering a substantial increase in strikes against supply lines and rear-area positions. ${ }^{45}$

The USAF had, during May, submitted a major report examining the potential use of atomic weapons in Korea, a study that provides an informative data-point regarding changing attitudes. The paper combined aggressive rhetoric, the scientific view of Korea as a giant laboratory, and a more developed understanding of ethical issues. The need for allies should an expanded war break out was brought home, especially as regards the basing of nuclear bombers in countries such as Britain. ${ }^{46}$ The report concluded that Korea presented no suitable atomic targets, whether strategic or tactical, and moreover:

[D]issipation of this stockpile without decisive results would lessen the

43 Truman, diary, May 18, 1952, in Ferrell (ed.), Off the Record, pp.250-251.

44 Crane, 'To Avert Impending Disaster', p.80; Stueck, Rethinking the Korean War, p.169.

45 Ibid.

46 USAF Staff Study on Use of Atomic Weapons in Korea, 'Inclosure “A”, Discussion', May 23, 1952, RG341, NARA, p.4. 
Soviet regard for US capabilities and would have serious adverse psychological effects on the morale of non-communist nations. ${ }^{47}$

Even the USAF, the most aggressive component of the US military machine, realised that, aside from important issues of terrain and targets, public fear and issues of morality held greater sway:

In fact, public reaction based on moral principles and fear of ultimate retaliation might assume such serious proportions that a significant portion of world and/or domestic opinion might become mobilised against the use of atomic bombs in general. ${ }^{48}$

Meanwhile, Clark's position was that only by a continued display of UN 'firmness'meaning both diplomacy and heavy bombing raids—would the communist negotiators be brought to any reasoned conclusions. ${ }^{49}$ He requested an increase in the forces available to him in order to apply pressure at the negotiating table. ${ }^{50}$ The tenor of Clark's request, with the implication of an escalation of the air war, suggests use of the atomic bomb, most likely in a tactical situation.

Concurrent with Clark, the State Department again attempted to find ways to utilise the threat of the A-bomb. On September 3, planners looked at methods of scaring the Chinese into accepting an armistice. The suggestion was to circulate a rumour that if the delegates at Panmunjom did not swiftly reach an agreement, then the bomb might finally be dropped. It was stated that 'The U.S. has consistently refused to accept prohibitions on the atomic weapons..$^{51}$ :

The reason for this is that the atomic bomb is our real ace in the hole in Korea, but the U.S. Government has been against their use. But pressure from some elements in the U.S. is intense to use them. The present saturation bombings in Korea have been launched in an effort to restrain these elements by satisfying them that we are taking vigorous action. ${ }^{52}$

\section{Furthermore:}

\footnotetext{
47 Ibid, p.7.

48 Ibid, p.5.

49 The Commander in Chief, United Nations Command (Clark) to the Joint Chiefs of Staff, September 1, 1952, FRUS 1952-1954, Vol.15, Pt.1, p.470.

50 Ibid, p.474.

51 Memorandum by the Deputy Assistant Secretary of State for Public Affairs (Phillips) to the Special Assistant to the Secretary of State for Public Affairs (MacKnight), September 3, 1952, FRUS 1952-1954, Vol.15, Pt.1, p.484.

52 Ibid.
} 
There is one way to prevent the use of atomic weapons in Korea. This is to get an armistice without delay. If that is not done and atomic weapons are used, they may not prove decisive since they have never been tried on troops in the field. If that happens, then the same pressure undoubtedly will be exerted to extend the bombings to China, using atomic weapons. ${ }^{53}$

The implication was that the way to avoid using atomic bombs in Korea was to threaten their use in order to force an armistice. The Charles Burton Marshall communications during the deployment of live nuclear weapons to Guam seemingly had an effect in bringing the Chinese to the negotiating table. If this had been the case, then surely further threats would provoke further concessions?

The veiled threats of nuclear annihilation were backed up by JCS discussions on lifting the A-bomb restrictions if the talks failed to produce tangible results. Their September 23 instructions to Clark noted that if the negotiations continued inconclusively, all restrictionsincluding those on the use of atomic weapons and the bombing of a China-might be removed. ${ }^{54}$ The reaction of the JCS fits the overall pattern of bluff and intimidation, born out the frustrating negotiations and the continued loss of life on the front-line. As a bluff, it dovetails well with other attempts, such as the September 3 memo, to make use of the threat of nuclear attack as a credible means of influencing events at Panmunjom.

However, for the administration in Washington, time had run out. While the war continued into 1953, the Democrats were trounced in the 1952 Presidential election. Truman had declined to run for another term, announcing during March that he would 'not accept a re-nomination. I do not feel that it is my duty to spend another four years in the White House. ${ }^{155}$ He backed the Governor of Illinois, Adlai E. Stevenson, as the Democratic candidate for President.

In an unsent letter of September 1952, meant for New York Times Washington correspondent Arthur Krock, Truman unleashed a revealing salvo of vitriol. 'Foreign policy has been costly.' he wrote, 'But World War III would have been ten times as costly. ${ }^{15}$ The President continued 'But when you contribute to the break-up of the foreign policy of the

53 Ibid.

54 The Joint Chiefs of Staff to the Commander in Chief, Far East (Clark) and the Commander in Chief, Pacific (Radford), September 23, 1952, FRUS 1952-1954, Vol.15, Pt.1, pp.527-528.

55 Truman, 'Address at the Jefferson-Jackson Day Dinner', March 29, 1952, PPHST, accessed on September 23, 2009.

56 Truman to Arthur Krock (unsent), September 11, 1952, in Ferrell (ed.), Off the Record, p.271. 
United States, you help bring on World War III. ${ }^{157}$ Truman thus viewed non-use as absolutely vital to standing back from the abyss of global war. Those who attacked his foreign policy only led the United States towards use of the weapon and thus towards the horrors of major confrontation. Declining to run for another term solved for Truman the stressful cognitive paradox of having the A-bomb but realising it was in practice un-usable. He no longer had to face the potential for use, being unwilling to see his legacy as that of the President who dropped the bomb on Japan and Korea.

Adlai Stevenson had spoken out against those who called for atomic weapons to resolve the situation in Korea. In a major campaign speech, which made much of the ideals of the late Brien McMahon who had died on July 28 1952, Stevenson decried A-bombs as 'weapons which destroy the guilty and innocent alike, like a terrible sword from heaven. ${ }^{158} \mathrm{He}$ spoke of the bomb being one part of a general system of defence, of the alarms that the American position had caused in allies, and the folly of America attempting to 'throw its atomic weight around. ${ }^{59}$ Stevenson never had the chance to implement his policies. He was roundly defeated by Eisenhower, who ran on a platform which attacked the foreign policy 'failures' of the Truman administration and contained a vague promise, 'I will go to Korea'. He orchestrated vast increases in the US arsenal and initiated the deterrence policy of massive nuclear retaliation.

The tail end of two and half painful years for America saw one of the most famous names from the war step forward once more. In response to a request for an informal meeting, Douglas MacArthur-still holding on to grandiose plans for the subjugation of China and unification of Korea—met with Eisenhower on December 17 1952. Giving lie to the mid-1951 statements that he never actually recommended the use of the atomic bomb, he heartily endorsed it as both threat and weapon. Referring to clearing opposition from North Korea, he recommended that:

[T] his could be accomplished through the atomic bombing of enemy military concentrations and installations in North Korea and the sowing of fields of suitable radioactive materials, the by-product of atomic manufacture, to close major lines of enemy supply and communications

57 Ibid.

58 Adlai E. Stevenson, 'Text of Gov. Stevenson's Address in Hartford on Atomic Energy', New York Times, September 19, 1952, p.16.

59 Ibid. 
leading south from the Yalu. ${ }^{60}$

The military dinosaur once more demonstrated that he was fatally out of touch with emerging realities. Trapped in a pre-World War II mindset where weapons were merely means to dispose of the enemy, MacArthur's significance would, as he said of himself in his farewell address to Congress, 'just fade away. ${ }^{161}$

Truman's bequest to Eisenhower was twofold. Ivy Mike, the first thermonuclear test, took place on November 1, 1952. The explosion—measured at 10.4 megatons, five hundred times more powerful than the bomb dropped on Nagasaki-obliterated the Pacific island of Elugelab. ${ }^{62}$ Even though the new technology would not be transformed into a full-fledged weapon until 1954, a whole new scale of destructive power had been ushered in. In January 1953, in one of the last acts of the administration, NSC-141 was approved. The paper was a restatement of the NSC-68 strategy developed prior to the Korean War, a bold plan to enhance civil defence and boost US striking power. ${ }^{63}$ In many ways, NSC-141 presented a plan that was more flexible, less focused on nuclear arms, than NSC-68. Korea gave a stern lesson in the need for conventional forces, even in the atomic era. This was, however, a legacy to Eisenhower.

During this period, extensive studies were carried out into the possibilities for tactical weapons use. The December 1950 ORO report was an early example of this. As technology progressed, military and political thinking struggled to catch up: the weapons were there, but the doctrine was absent. Mid-1951 through 1952 saw tactical thinking begin to undergo serious evolution. It is vital to note that despite this new focus on tactical use, the power of the weapons themselves had not changed. The yield of the weapons dropped on Japan now fell in to the 'tactical' range, although the weapons had become smaller and more portable. As Bernard Brodie, one of the most perceptive early thinkers on the tactical/strategic divide, opined 'the first A-bombs were tactical bombs as much as they were strategic; more so, in fact,

60 MacArthur, Reminiscences, p.411.

61 Ibid, p.405.

62 Richard Rhodes, Dark Sun: The Making of the Hydrogen Bomb, New York, 1995, p.510. One month earlier, on October 3, 1952, Britain had attained atomic capability with the Hurricane test.

63 NSC-141, 'A Report to the National Security Council by the Secretaries of State and Defense and the Director for Mutual Security on Re-examination of United States Programs for National Security', January 19, 1953, DNSA. 
since their yields were of a size now regarded as falling entirely inside the tactical range. ${ }^{164}$ The power of nuclear weapons was ever increasing and what had once been regarded as citybusting terror weapons were, in the face of multi-megaton thermonuclear weapons, relegated to battlefield use. The key point is that tactical weapons and delivery systems had become available, and Korea provided the crucible in which new thinking was formulated. Ultimately, all military theorising and planning had to challenge the larger and more powerful force that was the opinion of politicians and the public.

\section{OUTSIDERS}

The period from mid-1951 into 1952 showed a singular obsession on the part of Congress, the media, and the public: tactical nuclear weapons. Touted as awesome new developments that changed the battlefield forever., they re-invigorated the debate on use as Korea became a grinding war of attrition, a virtual stalemate where bodies piled up as the negotiations dragged on.

\section{Congress}

An even wider gap now opened between the evolved understanding shown by the administration and the A-bomb enthusiasm of politicians on Capitol Hill. While Truman and his colleagues had absorbed the lessons of Korea, many political outsiders demonstrated a lack of education in atomic matters.

Korea, and its relationship with the A-bomb, remained a topic for vigorous congressional debate, especially when the idea of tactical use entered the public consciousness. Brien McMahon was inconclusively quizzed on the topic on September 14, 1951 by journalists seeking his views on public demands for tactical A-bomb use. ${ }^{65}$ The next day W. J. Bryan Dorn (D-SC) entered into the Congressional record an article on the subject from the New York Herald Tribune. ${ }^{6}$ A September 16 article in the New York Times, however, castigated politicians who had found themselves caught up in the wave of excitement about these wondrous new

64 Brodie, Strategy in the Missile Age, p.325.

65 NA, 'M'Mahon Reports Wide Atomic Gains', New York Times, September 13, 1952, p.22.

66 W.J. Bryan Dorn, CRH (Appendix), 82/1, Vol.97, Pt.14, September 14, 1951, pp.A5596-5596 
developments. ${ }^{67}$

McMahon added further grist to the mill with a speech in Washington on September 25. He highlighted the 'cheapness' of atomic fire-power when compared to conventional forces and lambasted, but recognised the success of, Soviet propaganda in establishing the atomic bomb as an 'immoral weapon. ${ }^{168}$ And while McMahon was expressing his view, his old sparring partner Senator Hickenlooper made it plain that he saw tactical A-bombs as ideal for the Korean situation and that he favoured the use of such weapons. ${ }^{69}$

Senator Henry Cabot Lodge Jr. (R-MA) demanded the use of A-bombs in Korea, because 'no possible objection could be made to using the atomic weapon solely for tactical purposes. $^{.70}$ As many proponents of nuclear attack had done since June of 1950, he harked back to the widely held belief that use of atomic bombs would save many American lives, as had allegedly been the case in $1945 .{ }^{71}$ Lodge's remarks were picked up by the media, as were those made by future president Senator Lyndon B. Johnson (D-TX) who commented that a blunt notice should be sent to the Soviet Union, informing it that in future all retaliation would be directed against it, rather than the 'minion countries' that attacked US interests. ${ }^{72}$

A torrent of demands for use was heard as Congress disbanded for the winter in October-November 1951 and politicians returned home for Thanksgiving and Christmas. Overton Brooks, Zales N. Ecton (R-MT), J. Allen Frear (D-DE), Olin D. Johnson, and Robert Taft all took it upon themselves to call for atom weapons to be used in far-flung Korea. Brooks, who had already caused the minor media flap in May with his enthusiasm for tactical A-bombs, cited un-named 'authorities' in Washington who were considering atomic weapons usage, as well as stating that the A-bomb would mean fewer soldiers coming home in caskets. ${ }^{73}$ Frear suggested that dropping the bomb was the only way to conclude 'an endless and inconclusive war', while Taft favoured use against communist military forces, but certainly not

67 Cabell Phillips, '"Fantastic Weapon" Talk Contains Too Much Fantasy', New York Times, September 16, 1952, p.E10.

68 Entered into the Congressional Record by Olin D. Johnston, CRS (Appendix), 82/1, Vol.97, Pt.15, September 26, 1951, pp.A5936-5938.

69 NA, 'Atom Weapons Called Ready for Korean War', Chicago Daily Tribune, October 4, 1951, p.7.

70 Henry Cabot Lodge Jr., CRS, 82/1, Vol.97, Pt.10, October 11, 1951, p.12938.

71 Ibid.

72 NA, 'Senate Votes to Share Some Atomic Secrets', Chicago Daily Tribune, October 12, 1951, p.12; NA, 'Senate Approves Sharing Atom Data', New York Times, October 12, 1951, p.17.

73 NA, 'US Reported Weighing Korea Use of Atom Bomb', New York Times, October 14, 1951, p.38. 
civilians. $^{74}$ This provides an interesting contrast to Taft's earlier views, as he appeared to see the tactical bomb as a much lesser evil than strategic nuclear weapons. Ecton suggested that the new tactical bombs could stop any conceivable communist attack in Korea and urged their use to protect American lives. ${ }^{75}$ The flurry ended with Johnson retreating to comfortable probomb ground, resorting to a favoured metaphor. Using the A-bomb would put an end to 'fighting with our right hand tied behind us. ${ }^{76}$

The partisan nature of US politics at the time, with competition to see who was the most anti-communist, and therefore the most patriotic, influenced the stance of many in Congress. These were not all Republicans, but included disaffected Democrats who perceived the way the political wind was blowing and decided to save their careers, rather than their party. While the administration attempted to 'appease' the communists by engaging in armistice negotiations, outspoken critics bolstered their position by appearing tough and aggressive, safe in the knowledge that they were not the ones who would have to take the ultimate decision.

Mid-November 1951 witnessed further calls for use, provoked by allegations that US prisoners of war (POWs) had been massacred by communist troops. The flap was instigated by unauthorised statements to reporters from Colonel James Hanley, an Army war crimes investigator in Korea. ${ }^{77}$ Confusing and contradictory clarifications issued by Ridgway's command did not help the situation. ${ }^{78}$ Regardless of the facts, the issue caused many members of Congress to demand nuclear action against the 'barbarous' communists. Edwin Johnson (D-CO), Zales Ecton, John W. Byrnes (R-WI), W. Sterling Cole (R-NY), Fred L. Crawford (RMI) and J. Frank Wilson (D-TX) all made vocal demands for violent retaliation against the perpetrators. Wilson saw no moral issues in using the bomb and Byrnes stated that America 'should get about winning the war and stop piddling around. ${ }^{.79}$ The POW flap died down but highlighted that some saw the A-bomb as the ultimate punishment-rather ironically-for those committing acts of 'barbarism.'

74 NA, 'Atom Weapons Use Urged', New York Times, October 16, 1951, p.32; NA, 'Taft Blames Democrats for Red Build-up', Washington Post, October 29, 1951, p.2.

75 NA, 'New Battle Bombs Hailed By Senator', New York Times, November 10, 1951, p.5.

76 NA, 'Atom Bomb Use in Korea Asked', New York Times, November 13, 1951, p.3.

77 Casey, Selling the Korean War, pp.280-281.

78 Ibid, p.281.

79 NA, 'Red Atrocities Bring Demand "Use A-Bomb!"', Chicago Daily Tribune, November 15, 1951, p.1. 
In January 1952 Senator Lester C. Hunt (D-WY), coming to the issue a little late, suggested that the US held back from dropping the bomb in Korea through fear of Soviet retaliation. ${ }^{80}$ Later that month, Olin E. Teague (D-TX), who had just returned from a factfinding mission to Korea, made a call for use of the weapons. ${ }^{81}$ Hunt and Teague were two of an increasing band of Democrats who, like Bentsen, Frear, Wilson and others in previous months, had decided to align themselves with outspoken opinion rather than the administration line. Taft kept up his attacks on an administration thoroughly battered by the past two years, once more deriding Truman's foreign policy and making the claim that the only thing that kept the USSR from attacking was the A-bomb. ${ }^{82}$ In Truman's final days as President, with a Republican in the form of Eisenhower ready to take control, Cole, Hickenlooper and James E. Van Zandt (R-PA) swore to support the new leader if he chose to use the A-bomb to bring the Korean conflict to a close. ${ }^{83}$ Jockeying as they were for leadership of the JCAE, their proclamations at the moment Truman left office were self-serving attempts to win favour with the incoming administration. However, it was nonetheless indicative that they expected that to be accomplished by voicing their enthusiasm for atomic warfare.

\section{Foreign Relations}

Foreign alliances impinged upon US government thinking throughout 1951 and 1952. A series of Anglo-American and Canadian-American talks regarding atomic weapons took place throughout this entire period. Much of the diplomacy related to the basing of the SAC strike force beyond the borders of the United States in preparedness for an all-out war in the event that things went awry in Korea.

In mid-July 1951 the Canadians, represented by Ambassador Humphrey Wrong, strove to find out what the constitutional position of the three allies was in the event that decisions regarding a nuclear strike had to be made with extreme rapidity. ${ }^{84}$ Nothing was agreed at this meeting, but the Canadians received a more positive response when, on July 27, Nitze stated

80 NA, 'Swift Retaliation by Russians Expected If We A-Bomb Korea', Washington Post, January 5, 1952, p.2.

81 NA, 'Teague Would Drop A-Bombs in N. Korea', Washington Post, January 29, 1952, p.2.

82 NA, 'Taft, Russell Debate US Foreign Policy', New York Times, April 23, 1952, p.16.

83 NA, 'Hill Leaders Favor Using Atom In Korea', Washington Post, January 9, 1953, p.2.

84 Memorandum of Conversation, by the Special Assistant to the Secretary of State (Arneson), July 13, 1951, FRUS 1951, Vol.1, p.855 
that they should expect to receive communications on the matter directly from him. ${ }^{85}$

While the Canadians were thrashing out their arrangements, a series of ongoing Anglo-American summits were also taking place. Vandenberg was concerned that the British were trying to extricate themselves from commitments—such as the basing of nuclear forces in the UK and the agreement to support retaliatory action in the event of Chinese air attacks in Korea - they had made regarding atomic weapons. ${ }^{86}$ The views of the USAF chief were not shared by Bradley, Collins, and others. ${ }^{87}$ Indeed, Nitze considered the discussions the ideal opportunity to obtain 'an understanding with the British on the use of atomic weapon in contingencies not covered by treaties. ${ }^{18}$

The next meeting regarding the Anglo-American situation drew together the JCS and the Secretaries of State and Defense. Bradley worried that the ongoing talks might result in some undesirable commitment—-such as having to engage in lengthy discussions prior to use of atomic weapons-to the UK and Acheson related this back to the Truman-Attlee communiqué of December $1950 .^{89}$ He continued by drawing a direct line, in the public consciousness, between use of atomic weapons and general war. ${ }^{90}$ Possible Soviet entry into Korea and whether or not this would precipitate war was the subject of considerable debate. Lovett wanted to avoid US allies restricting A-bomb use only to circumstances of general war, concerned that the US might at some point want to use the bomb in a war with the USSR that was not general. ${ }^{91}$

The British Labour government's enthusiasm for obtaining some form of agreement with the US was motivated, at least in part, by the upcoming October 1951 general election, which it subsequently lost. Attlee and his party wished to position themselves as having influence in world affairs and on US policy. The Labour Party even went so far as to proclaim that in December of 1950, its swift action taken in demanding a summit with Truman had

85 Memorandum of Conversation, by Mr. Joseph Chase of the Office of the Special Assistant to the Secretary of State, July 27, 1951, FRUS 1951, Vol.1, p.860.

86 Memorandum of Conversation, by Mr. Robert Tufts, Member of the Policy Planning Staff, August 1, 1951, FRUS 1951, Vol.1, p.866.

87 Ibid.

88 Ibid.

89 Memorandum of Conversation, by the Deputy Director of the Policy Planning Staff (Ferguson), August 6, 1951, FRUS 1951, Vol.1, pp.875-876.

90 Ibid, p.877.

91 Ibid. 
saved the world from a third global conflict. ${ }^{92}$

In face-to-face discussions, the UK delegation pressed for assurances regarding the use of atomic weapons. The principal matters of concern were consultation on use and the basing of A-bombs in the UK. Firmer guarantees were desired, something that Acheson and his colleagues were unwilling to give..$^{3}$ The connection of major war and nuclear weapons use, and the far reaching global implications thereof, was something that could not be set aside and Herbert Morrison — who had agreed in principle to retaliation against Chinese air attackswanted clarification. It would be rather awkward for the British Government, he said, if the first they knew of atomic strikes by US bombers based in the UK was when the weapons detonated. ${ }^{94}$ But the US did not acknowledge these difficulties and the talks, like the negotiations in Korea, seemed stuck in mire.

While discussions continued between the US, the UK, and Canada, the State Department remained interested in broader allied perceptions of the atom bomb. In a vein similar to the February 1951 study into the A-bomb as an 'immoral weapon', the Office of Intelligence Research (OIR) produced 'Reactions of the United Kingdom and France to an Assumed Proposed Use of Atomic Weapons by the US'. The report, like its predecessor, tapped in to the twin British sentiments of fear of the atomic bomb and a belief that the weapon was somehow immoral. ${ }^{95}$ The paper suggested that the British and French viewed tactical use of the A-bomb with much less anxiety than they did strategic use. ${ }^{96}$ This point was qualified by the statement that there was concern regarding the maintenance of a distinction between tactical and strategic use. ${ }^{97}$ Invoking vivid phraseology from George Orwell's dystopian novel 1984 (published in 1949) the report's authors suggested that many in Britain saw the US using their country as 'airstrip one'. ${ }^{8}$ With the British general election looming, and the chance that the Conservatives under Churchill might regain power, the OIR indicated that a Conservative government might show considerably less interest in the moral dimension,

92 NA, 'Attlee Averted War, Labor Party Claims', Washington Post, August 28, 1951, p.5.

93 Memorandum of Conversation, by the Ambassador at Large (Jessup), September 11, 1951, DNSA, p.2.

94 Ibid.

95 Office of Information Research, OIR Report No. 5619 'Reactions of the United Kingdom and France to an Assumed Proposed Use of Atomic Weapons by the US', September 17, 1951, DNSA, p.1.

96 Ibid.

97 Ibid, p.1-2.

98 Ibid, p.2. 
something that would be helpful to the US.99 Overall, it was suggested that British reservations about using the bomb 'primarily apply to Korea-like situations of the cold war [sic]. ${ }^{100}$

French opinion was characterised as being implacably opposed to the use of atomic weapons in any circumstances short of a general war and furthermore being of the belief that any use of the A-bomb would mean general war. ${ }^{101}$ The authors also put forward the more pro-bomb opinions of another wartime leader, Charles de Gaulle. De Gaulle was positioned as being more flexible in his view of atomic weapons and their potential for use in situations outside of a major war. ${ }^{102}$ But aside from De Gaulle, who was at that time in the political wilderness, French opinion was regarded as being anti-nuclear, in particular if the US chose to undertake a strategic bombardment of the USSR in the event the latter became involved in Korea. ${ }^{103}$

In general terms, the OIR paper offered similar conclusions reached much earlier in the war by other reports. British and French opinion was predominantly against atomic weapons usage outside of the most extreme circumstances. The importance of these nations to American nuclear strike capability could not be ignored. ${ }^{104}$

Churchill, now Prime Minister for the second time, met the embattled Truman in Washington in early January 1952. At the outset of the confidential meeting, Truman was at pains to make it known that he was reluctant to use the weapon and that he never wanted to use it to wipe out populations. ${ }^{105}$ Lovett opened the discussion proper and immediately brought up the recurring issue of tactical use and continued that, if World War III were to break out, then nuclear weapons would have to be used. ${ }^{106}$ Significantly, the issue of public opinion and public attitudes came front and centre during the talks. Truman commented that atomic issues created an atmosphere of hysteria in the United States and, in closing the meeting, warned that the press should not be informed atomic issues had been discussed. ${ }^{107}$ Public pressure had obviously shaped the administration stance on non-use. Their education

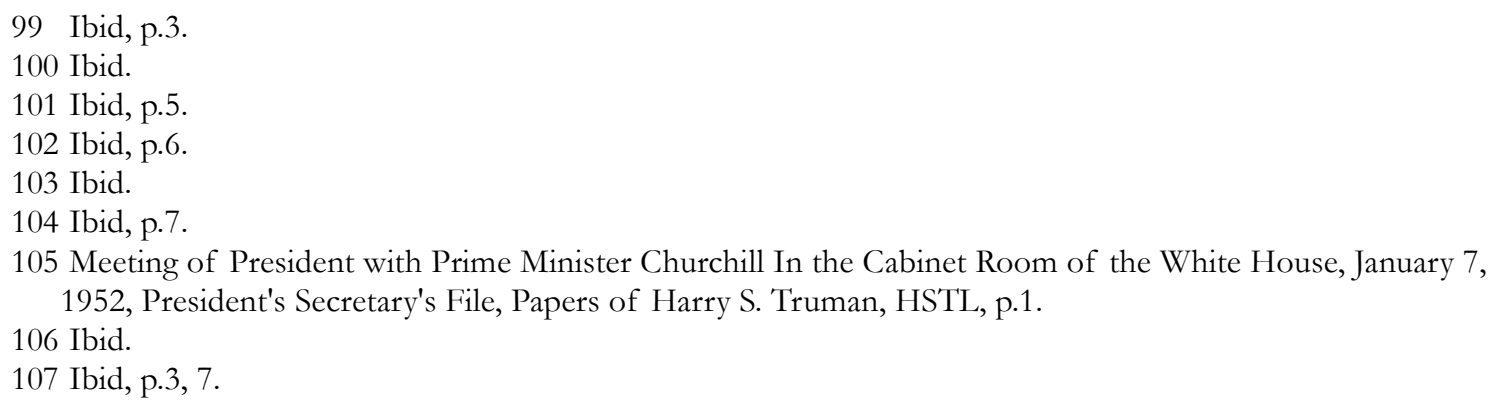


was such that they now realised that even discussion of use in the context of a global war would need to be managed and, as in this case, hidden from view.

The May 1952 USAF staff study on atomic weapons in Korea made foreign opinion and foreign relations key themes. It was absolutely vital to be able to justify the US position, should the weapons be used. ${ }^{108}$ However, making use of the A-bomb in Korea would be disadvantageous to the overall US position where 'the political implications of employing atomic weapons...outweigh any military gain which might be anticipated under present circumstances. ${ }^{109}$ Even the military was now well-educated regarding foreign relations.

Until the end of the Truman administration, foreign opinion was a force shaping nonuse of atomic weapons. Political, strategic and moral interests all intersected under the banner of maintaining a strong 'Western' coalition against communism. The United States had to maintain good relations with its allies to be ready for the long awaited Soviet strike into Western Europe. Had tactical weapons been used, perhaps against mountain fortifications invulnerable to conventional bombardment, the coalition arrayed against the communist forces might have suffered irreparable fractures, threatening the containment of communism in Europe. Even using the A-bomb against a target which was undeniably military in nature would have created such an outcry as to make the US position as the moral, as well as physical, leader of the UN forces practically untenable.

\section{Public Opinion}

Reflecting public fatigue with a conflict that had dragged on for months, correspondents to the major newspapers became even keener to see the war drawn to a close. And some thought that the A-bomb should be used to finish things, although it is true others preferred more peaceful means. 'Tactical atomic weapons would certainly blunt the ambitions of the North Koreans,' wrote John Hooven in the Washington Post, 'and through long-range bombers, the threat of almost certain oblivion can be literally "brought home" to those with whom rests the decision for all-out war. ${ }^{110}$ But another writer, reflecting on the November 1951 POW massacre flap, considered cries to drop atomic weapons nothing more than

108 USAF Staff Study on Use of Atomic Weapons in Korea, 'Inclosure “A”, Discussion', May 23, 1952, RG341, NARA, p.4.

109 Ibid, 'Conclusions', p.3.

110 John G. Hooven, 'Atomic Armament', Letter, Washington Post, September 22, 1951, p.8. 
Americans allowing themselves to be 'transformed into a savage, blood-thirsty, frenzied mob. ${ }^{111}$

Some correspondents harked back to themes common throughout the war, explicitly claiming that events on the peninsula had resulted in the same situation as that produced by Munich in $1938 .^{112}$ Furthermore, a favoured cliché reappeared: 'Fighting with one hand tied behind our back, we continue the stalemate war and refuse to punish the enemy. ${ }^{113}$ Some took a more nuanced stance in mid-1952, asking the question 'Does Mr. Taft wish to bomb Chinese cities and align the entire East against us? ${ }^{114}$ The same ideas arose again and again: race, the position of the US in world affairs, limitations on American fighting capability, 'cowardly' appeasement. Some even went so far as to suggest that using the atom bomb might prevent a third world war.

Many letters referenced the end of World War II and concluded, as others had done before them, that the A-bomb should successfully end the Korean War with statements such as 'We use the atomic bomb in the Second World War to reduce the cost of further conflict. We must act now to end the military conflict even though we fail to achieve every objective that we would like."115 US exceptionalism was stressed in remarks such as "We shall use whatever weapons are necessary to enforce justice and decency in the world, and there is no country with a better right to do this than the United States. ${ }^{116}$

As 1952 ended and the American people looked not to Truman, but to Eisenhower, who would take office in late January 1953, correspondents to three different newspapers struck upon common themes: that of morality and the potential for global war. One writer noted that 'Peace cannot be achieved thru [sic] violence' and people should not believe that moral considerations held back the leaders of the two superpowers. ${ }^{117}$ Another correspondent suggested that positioning the United States on the moral high ground was being somewhat disingenuous. 'There is no reason to think,' he wrote 'that the Western Powers are morally incapable of using the atomic bomb. We must never forget that this country used the bomb

111 Jessie B. Solomon, 'Atrocities', Letter, Washington Post, November 26, 1951, p.10.

112 Anthony Trawick Bouscaren, 'Time For Action', Voice of the People, Chicago Daily Tribune, March 10, 1952 , p.18.

113 Ibid.

114 Goodhue Livingston Jr., 'Taft Stand Opposed', Letter, New York Times, June 5, 1952, p.30.

115 Lewis F. Manly, 'Halt in Korean War Urged', Letter, New York Times, August 1, 1952, p.16.

116 Walter F. Smith, 'Use of Atomic Weapons', Letter, New York Times, December 3, 1952, p.32.

117 Robert A. Anderson, 'Russia Can Hit Back', Letter, Chicago Daily Tribune, December 10, 1952, p.22. 
not once, but twice. ${ }^{118}$ Finally, a solemn note was struck: the incoming administration had to take some fateful decisions regarding the course of the Korean War. If civilisation were to be preserved, 'we had better start thinking hard—all of us_of ways to prevent the spread of the Korean War and to control war in the future. ${ }^{119}$

Public opinion polling directly linking Korea and the atom bomb had disappeared by early 1951, but considerable effort was still made to gauge general opinion about the conflict. In July of 1951, seventy-four percent of Americans polled thought that it was a good idea for the UN to engage in peace talks in Korea. ${ }^{120}$ But, however strong the belief that negotiations were a good thing, very few people believed that they would do any good. Sixty-seven percent of respondents in a September poll indicated that they thought the Chinese did not want peace and fifty-nine percent thought that no negotiated settlement would be reached. ${ }^{121}$ By April of 1952, a majority of Americans believed that a mistake had been made in going into Korea, with a substantial number of the opinion that 'the enemy' had won the bigger victory. $^{122}$

Administration concern with public opinion was reflected in the approval by Truman and the NSC on March 27 of a Psychological Strategy Board report on the handling of atomic issues. ${ }^{123}$ The report noted that conflicting statements throughout the war had heightened fears_-foreign and domestic — and reduced confidence in administration handling of the A-bomb. ${ }^{124}$ The authors advised against ill-considered statements-such as the 'consideration' comments by Truman in December of 1950 — and formulated a rationale for any future mention of atomic arms:

1. Will this information strengthen the morale of the free world?

2. Will this statement at this time help the American public to understand and accurately appraise the capabilities of these weapons?

3. Will this statement create the fear that the US may act recklessly in the use of these weapons? ${ }^{125}$

118 Elwood Cronk, 'Prophecy', Letter, New York Times, December 14, 1952, p.SM6.

119 Orr Pielle, 'Far Eastern War', Letter, Washington Post, December 14, 1952, p.B4.

120 Gallup, The Gallup Poll, Vol.2, p.998.

121 Ibid, p.1017.

122 Ibid, p.1052.

123 Report to the National Security Council by the Psychological Strategy Board, February 28, 1952, FRUS 1952-54, Vol.2, Pt.2, p.870n3.

124 Ibid, p870.

125 Ibid, p871-872. 
In signing off the report, thereby making it official policy, Truman and his closest advisors demonstrated how important public opinion was to them and how, when it came to use or non-use, they must have the American people on their side. The administration had to make a consolidated effort to counter the anti-bomb propaganda of the Stockholm Peace Appeal, which by this point had gained over 600 million signatures around the globe, most of them from communist nations. ${ }^{126}$ As Lawrence Wittner perceptively argued 'The advocates of tailoring American pronouncements on nuclear weapons to the needs of Cold War propaganda apparently won the battle. ${ }^{127}$

Even the USAF—having struggled to ascertain during Hudson Harbor that the A-bomb would be usable in Korea-had come to recognise the importance of public opinion. In the May report, they came to realise that any use of the weapon could backfire dramatically. A remarkably perceptive paragraph argued:

Actual use of atomic weapons of any sort might serve to generate serious US domestic opposition to the policy and endanger that national unity required for a successful politico-military foreign policy. In fact, public reaction based on moral principles and fear of ultimate retaliation might assume such serious proportions that a significant portion of world and/or domestic opinion might become mobilized against the use of atomic bombs in general. ${ }^{128}$

For an institution such as the USAF, this displays a surprising level of nuanced understanding. The primary concern shines through: if the A-bomb was misused in Korea, would they ever be able to justify its use in the future?

Truman's final address to the American people, a valedictory speech that summed up the successes and failures of his administration, put forth in the clearest terms his thinking on the atomic bomb and Korea. 'Now, once in a while, I get a letter from some impatient person asking, why don't we get it over with?' Truman stated, continuing:

Why don't we issue an ultimatum, make all-out war, drop the atomic bomb?

For most Americans, the answer is quite simple: We are not made that way. We are a moral people. Peace is our goal, with justice and freedom. We cannot, of our own free will, violate the very principles that we are striving to defend. The whole purpose of what we are doing is to prevent world war

126 Wittner, One World or None, p.185.

127 Ibid, p.274.

128 USAF Staff Study on Use of Atomic Weapons in Korea, 'Inclosure “A”, Discussion', May 23, 1952, RG341, NARA, p.4-5. 
III. Starting a war is no way to make peace...A third world war might dig the grave not only of our Communist opponents, but also of our own society, our world as well as theirs.

Starting an atomic war is unthinkable for rational men. ${ }^{129}$

Truman, despite his outbursts and fits of temper, was a rational man. Yet, the possibility of use always sat on the margins of policy and debate. To the outside world, Truman had, for the most part, been rational and assured. However, within his own mind he was deeply conflicted, torn between the horror of Hiroshima and a desire to confront the communists with American power.

Public enthusiasm for the war had clearly plummeted since the early days of 1950. By the time of Eisenhower's inauguration as President in January 1953, the American people were disillusioned with the stalemate in Korea and keen to see the conflict ended. This fatigue is expressed in the tone of letters to newspapers and in the responses to polls. Even the atomic bomb had become more problematic and less of a certainty. The weapon had created more problems than it could possibly solve.

\section{CONCLUDING REMARKS}

The time from mid-1951 until Truman's exit in January 1953 was one that saw increased understanding of atomic issues, an awareness of the limitations of the weapon, and a paradoxical desire to utilise its existence. Unlike April 1951, no complete atomic weapons were ever shipped from the United States at any point: the main administration theorising on the A-bomb was wholly as a means to intimidate. There was an expanded understanding of how the world would react to atomic provocations, with politicians and senior soldiers reaching a point where they realised the limitations of any atomic ambition.

There were, however, important changes that brought new ideas on to the table. The rise of nuclear weapons as tactical instruments created a range of possibilities. If weapons of limited destructive power could be used against purely military targets in a war situation, then surely consideration must be given to their employment? But, any such considerations once more ran up against the ethics of using the bomb, the threat of expanded war and the public

129 Truman, 'The President's Farewell Address to the American People', January 15, 1953, PPHST, accessed on September 21, 2009. 
mood. However small the bomb and however limited its use, an A-bomb was an A-bomb. Their fundamentally different character, their position within the public consciousness as a weapon beyond mere bullets and shells, placed insurmountable restrictions on their use. However valid the military need for a swift, destructive strike, there was always the inescapable fact that any atomic use was bound to provoke extreme reactions.

Bruce Cumings, in a manner similar to his assessment of the 'consideration' comments, viewed Hudson Harbor as a sequence of events that sent an aggressive message to the Communist leadership. ${ }^{130}$ But, as Conrad Crane pointed out, given the flight-paths, cover story and nature of the missions themselves, it is extremely unlikely that DPRK, PRC or Soviet leaders could have deduced their real purpose. ${ }^{131}$ Going beyond the material aspects of Hudson Harbor, the administration, aware of the worldwide adverse reaction to atomic discussions, kept the true nature of the project firmly under wraps.

In Britain, the departure of Attlee and the return of Churchill furthered the subtle change in the relationship between the US and the UK. Churchill was less averse to the idea of using the A-bomb in some capacity and came, to American eyes, without the supposed quasicommunist baggage of Attlee.

The time, if there ever was one, for atomic weapons to decisively influence the course of the war was past. Korea had become a static war, with men dying as protracted armistice negotiations started, stalled and then started again. Clark, with his massive conventional bombing campaigns against the North, was having precious little influence on the course of events at Panmunjom. It is therefore unlikely that atomic strikes would have any positive effect. Indeed, it is all too likely that they would have managed to provoke the Soviet Union into reluctantly taking part in the fighting. The time for making potentially unpopular decisions had now passed. The 1952 Presidential election, that the Democrats had no real hope of winning, loomed large. Truman therefore chose to leave difficult choices regarding the Abomb to his successor, whether that individual be Democrat or Republican.

130 Halliday and Cumings, Unknown War, p.165.

131 Crane, 'To Avert Impending Disaster', p.87n15. 


\section{Conclusion}

This thesis has examined the factors contributing to the non-use of nuclear weapons in the Korean War during the Truman administration, June 1950 to January 1953. It has studied both the decision makers-the President and other senior members of the administration, and leading political and military figures — and those who stood outside the halls of power-members of Congress, the media, the scientific community, and the general public. Examining in detail this broader range of experience, influence, and opinion allows a more nuanced view of the issue.

This thesis also broadens the exploration of the issue through time. It examines the major periods of crisis - the outbreak of war in June 1950, the intervention of the PRC in November 1950 and the fear of Soviet intervention in April 1951. These are the focus of Chapters One, Two and Four. But the thesis also explores in depth the 'in between' periodsDecember 1950 to March 1951 (covered in Chapter Three) and the events through the battlefield stalemate from mid-1951 to the end of the administrations term in office, in January 1953 (Chapter Five). Developments bearing on non-use occur as much in these 'in between' periods as in the crisis periods.

As was shown in Chapter One, the outbreak of the Korean War came as an immense shock to American strategic calculations. The United States prompted the UN resolution that drew together a coalition to resist North Korean aggression. However, this early phase of the conflict was characterised by fears that the DPRK invasion-backed, it was assumed in Washington, by the USSR and PRC_-presaged a much wider communist assault on the West. The atomic bomb was brought into discussions on the very first day of the war and remained a factor in debate for the next three years. This chapter also illuminated the character of Truman and the paradoxical situation he found himself in: horrified by the effects of the atomic bomb and at the same time fully aware of its importance in America's stand against communism. Truman placed himself under a mental strain that would last until he absolved himself of responsibility for nuclear decision-making by refusing to run for the Presidency in 1952. 
When, on November 30 1950, Truman responded to the goading of the press with the statement that nuclear weapons had always been considered as tools to aid the war effort, the world exploded in uproar. As Chapter Two demonstrated, this period was vital in the 'nuclear education' of the Truman administration, highlighting the extreme response to the merest mention of the A-bomb. Also of significance were the accusations of 'appeasement' levelled at the administration when they chose not to use the full power of the atomic arsenal against the Chinese armies. Fully aware of the weight of such accusations—redolent as they were of Chamberlain, Munich, and the Nazis-Truman and his colleagues formulated plans to offload the blame for the strategy onto British Prime Minister Clement Attlee. Appeasement accusations form a previously underestimated influence on Truman and the administration. The 'offloading' was not enacted and this strand of criticism would continue to provoke debate throughout the Korean War.

The events of early December were followed by a three month period that has received too little attention in the existing scholarship. Chapter Three analysed this period in detail, showing how ongoing fear of global war, further accusations of appeasement, the influence of foreign opinion, and increasing awareness of the subtleties of atomic diplomacy all contributed to the picture of non-use. This chapter also showed key findings related to the pressures acting on Douglas MacArthur. Rather than simply requesting atomic bombs for use in Korea because of his aggressive personality — which was undoubtedly a contributing factor-he was also provoked by defence intellectuals providing pro-bomb intelligence and the demands of a JCS desperate for his opinions on the situation.

In sum, the events of this period demonstrated that non-use was never off the table and that extreme positions — such as those expressed by Stuart Symington in NSC-100—were also ruled out. In analysing the State Department efforts to better understand foreign opinion in this period, this thesis refutes the findings of Calingaert that in Korea U.S. policy refused to allow outside restraints to limit its freedom to atomic weapons. The U.S. found itself restrained on a fundamental level by foreign powers, shackles that it would however attempt to throw off in the coming months.

Chapter Four covers the third crisis period. So terrifying was the situation in April 1951 — with intelligence indicating that the PRC and USSR were planning massive air assaults 
on UN forces in Korea-that Truman overcame his horror of making any commitments to use the bomb. In deploying fully functional nuclear weapons to Guam in April 1951, Truman took a step that had not been taken since 1945. Despite this singular move towards nuclear use, Truman remained conflicted about the atomic bomb. He remained determined never to make that final order for use, but the deployment-and his willingness to dismiss the overly aggressive and confrontational MacArthur - demonstrated a new sophistication in how atomic weapons might be used. Little mentioned by Calingaert, Dingman, Tannenwald, and others, was the subtle, but remarkable, change in the British position on atomic use. Foreign Secretary Herbert Morrison gave his tacit agreement to nuclear use under limited circumstances. This demonstrates that, as time went on, the Truman administration began to mould the opinion of its allies to its way of thinking, rather than vice versa-this too was a demonstration of an enhanced subtlety in its approach and a particularly important finding from this period.

Chapters Three and Four taken together also demonstrated the influence of the individual on non-use. General Matthew Ridgway, first as field commander and then taking overall command from the dismissed MacArthur, stabilised the situation on the battlefield, reinvigorated the troops, and reduced the fear that the U.S. might have to resort to the Abomb to save face.

Covering the months from July 1951 to January 1953, Chapter Five threw a spotlight on the evolving theory of tactical nuclear weapons use and how that debate intersected with non-use. Prior to the 'tactical revolution' engendered by the Korean War, nuclear weapons had broadly been seen—with some notable exceptions—as purely strategic instruments. Korea demonstrated the dangers of potential strategic use and therefore pushed planners towards the search for battlefield uses. Notions of the tactical applications of the A-bomb provoked great debate in Congress and the media, with key figures from the administration stoking the fire. By this stage in the war, however, the time for nuclear weapons to decisively influence the course of events had passed. Korea had become a static war and as this thesis has found, in such an environment, there could be little, if any, justification for employing weapons as powerful as the atomic bomb. 
Broadening the enquiry in both these ways-across experience and time-provides insights that have not been seen in previous studies. Roger Dingman made an immense contribution to the study of non-use in Korea with his seminal paper 'Atomic Diplomacy During the Korean War.' In many ways, the work of Dingman is the bedrock upon which study of this vital issue sits. However, his work is, and quite rightly should be, open to reevaluation and re-interpretation. Dingman took a highly institutionalist and materialist approach, which tended to see institutions within the U.S. system and debates such as the availability of atomic targets in Korea as the key factors. His division of the war into four case studies (three of which related to the Truman administration) does not give the full picture of non-use. By expanding the breadth and depth of the examination, this thesis shows that while Dingman was correct in many of his assertions, the reasons behind non-use were far more varied and nuanced than he argued.

This thesis adds to Dingman's work by showing that the fear of World War III resulting from the conflict in Korea was always an issue for insiders and outsiders alike. From the earliest days where it was suspected that Korea was the first of a series of communist moves against the West, to the final days when recalcitrance at the negotiation table was viewed as a stalling tactic prior to a massive attack that fear of provoking World War III never subsided. Hence, the terrifying prospect of a global war between East and West served to exert a restraining influence.

The influence of accusations of appeasement is an area that has received little attention in the existing scholarship. It is argued that such accusations-with which political opponents and the general public alike bombarded the administration and that were most notable in their effect during the 'consideration' débâcle of December 1950—had a noticeable impact on key actors such as Truman and Acheson. The accusations caused restraint due to the knowledge within the administration that nuclear use would lead to global war. Cries of 'appeasement!' served not to push Truman and his colleagues towards use, but served to push them away from nuclear use by making it clear that they had to limit the war even though still determined to confront the 'aggressor'.

Tannenwald forcefully argued that the most—but not the only_-significant factor in determining non-use during the Korean War was the moral factor, the 'nuclear taboo.' It has 
been the contention of this thesis that, while important, the emerging taboo did not occupy as important as role as Tannenwald posits. This is not to say that ethical and moral concerns were not expressed and did not have influence: notions of the morality of the A-bomb were highlighted in official documentation, speeches, and public commentaries. However, in using the Korean War as the platform upon which she builds her thesis on the growth and importance of the nuclear taboo during this period, she overstates the significance of this area and understates the importance of, for example, the fear of World War III and the role of individuals_-such as Matthew Ridgway_other than Truman.

The non-use of the atomic bomb in Korea is a wide-ranging topic that contains many pieces which make up the overall picture. World opinion served to create a barrier against use. This was expressed in many ways. From a practical point of view, the United States could not afford to lose the goodwill of the UK and France if it wished to base its advance nuclear strike force in Europe. The need to retain alliances in order to have adequate striking power against the Soviet Union in the event of a major war was paramount in the minds of many.

Likewise, the opinions of other nations helped to reinforce the moral and ethical arguments against use. The issue of race was brought to the table on more than one occasion. The majority of Asian nations perceived the A-bomb as a fundamentally racist weapon, one that white powers only ever used on non-white people. If the bomb were used against Korea or China, the United States would lose the support of allied and non-aligned nations in its fight to enact the policy of containment. The question of race was reflected in official documentation and public discourse: some more extreme U.S. citizens viewed Korea as nothing more than a long awaited 'race war' and heartily encouraged the use of the atomic bomb against 'the yellow race'.

When taking into account the significant role of the individual in the attitude the U.S. displayed towards nuclear weapons during the Korean War, it is clear that the personality of Harry Truman had a major influence in this matter. His internal conflict over the A-bomb filtered down into civilian and military planning, inhibiting the creation of doctrines that would have more easily allowed active deployment of the weapons.

John Lewis Gaddis astutely suggested that in the case of Truman, his education in 
atomic matters was far in advance of that of everyone else. He argued that the President realised, even before the Korean War, that the A-bomb had utterly changed the very nature of strategy itself. ${ }^{1}$ Gaddis' erudite final analysis is worth repeating in full:

Little noticed at the time nor widely remembered since, Truman's January 1953 valedictory anticipated the difficulties all of his successors would have-as would those elsewhere in the world who would come to possess them-translating the physical power of nuclear weapons into effective instruments of statecraft. The absence of coherent strategy in the Truman administration, therefore, may have demonstrated not so much lack of sophistication as an abundance of it. Truman's nuclear education simply preceded that of everyone else. ${ }^{2}$

Truman was, without question, the most significant single actor in the entire drama. Yet, there are other figures that must be given due credit for non-use. Matthew Ridgway, in reversing the rout to the south in early 1951 and re-invigorating the UN war effort, must be held up as an example of an individual who, by his actions, made a major contribution to non-use. Through his skilled command, Ridgway greatly reduced the potential for use. Had the unfortunate death of his predecessor, Walton Walker, not taken place, it is all too likely that a retreat from Korea might have taken place, a retreat that could only be compensated for by atomic bombardment.

Such is the complexity of the issue and the scope of archival material related to it, that there remains further scope for study and investigation, for example into the perceptions of soldiers on the ground regarding the potential for A-bomb use or the further implications of the racism accusation in nuclear planning. However, this thesis has shown that it was a broad range of factors - many of which were inherent in world affairs at the time- that pushed the Truman administration in the direction of non-use. That the bomb never dropped on Korea is something that all of humanity can be truly thankful for. The outcomes of such an act, even in this early stage of the Cold War, before the incredible destructive capacity of the multimegaton hydrogen bomb was brought to the fore, would have been nothing less than calamitous. In the end, one man had the ability to start a global war. The fact that Truman did not prevented his legacy from being that of the President who had ended one world war with the A-bomb and started another with the same weapon.

Gaddis, We Now Know, p.112.

Ibid. 


\section{Bibliography}

\section{Documentary Sources}

\section{Published Documentary Sources}

The Biographical Directory of the United States Congress, 1774-Present, at http://bioguide.congress.gov/biosearch/biosearch.asp

The Bulletin of the Atomic Scientists Archive, at http://books.google.com/booksid=9gsAAAAAMBAJ\&source=gbs navlinks s\#all issues a nchor

Ferrell, Robert H. (ed.), Off the Record: The Private Papers of Harry S. Truman, New York, 1980

Gallup, George H., The Gallup Poll: Public Opinion 1935-1971, Vol.2: 1949-1958, New York, 1972

Pitts, Denis \& Crow, D., Clem Attlee: The Granada Historical Records Interview, London, 1967

The Public Papers of Harry S. Truman, at http://www.trumanlibrary.org/publicpapers

The Time Archive, at http://www.time.com/time/archive

US Department of State, Foreign Relations of the United States, 1950, Vol.1, National Security

Affairs; Foreign and Economic Policy, Washington DC, 1977

1950; Vol.4, Central and Eastern Europe; The Soviet Union, Washington, DC, 1980

1950, Vol.7, Korea, Washington, DC, 1976

1951, Vol.1, National Security Affairs; Foreign Economic Policy, Washington, DC, 1979

1951, Vol.7, Korea and China, Washington, DC, 1983

1952-54, Vol.2, National Security Affairs, Parts 1 and 2, Washington, DC, 1984

1952-54, Vol.14, China and Japan, Parts 1 and 2, Washington, DC, 1985

1952-54, Vol.15, Korea, Parts 1 and 2, Washington, DC, 1984

US Congress, Congressional Record, Vol.96, Part 8, Washington, DC, 1950

Vol.96, Part 12, Washington, DC, 1951 
Vol.97, Part 6, Washington, DC, 1951

Vol.97, Part 10, Washington, DC, 1951

Vol.97, Part 14, Appendix to the Congressional Record, Washington, DC, 1951

Vol.97, Part 15, Appendix to the Congressional Record, Washington, DC, 1951

Wunderlin, Clarence E., Jr., The Papers of Robert A. Taft, Vol.4, 1949-1953, Kent (OH), 2006

\section{Unpublished Documentary Sources}

The CIA Freedom of Information Electronic Reading Room, at http://www.foia.cia.gov

The Digital National Security Archive, at http://nsarchive.chadwyck.com/home.do

The Harry S. Truman Presidential Library, Independence, Missouri

Papers of Dean Acheson

Papers of George M. Elsey

Papers of Harry S. Truman

Naval Aide Files

President's Secretary's Files

The United Kingdom House of Commons Parliamentary Papers Online, at http://parlipapers.chadwyck.co.uk/home.do

The United States National Archives and Records Administration, College Park, Maryland.

Record Group 59, General Records of the Department of State

Record Group 319, Army Staff

Record Group 341, Headquarters United States Air Force (Staff)

\section{Newspapers}

All sourced from ProQuest Historical Newspapers database, at http://www.proquest.com/en$\underline{\mathrm{US} / \text { catalogs/databases/detail/pq-hist-news.shtml }}$

The Chicago Herald-Tribune, 1950-53

The Los Angeles Times, 1950-53

The New York Times, 1950-53 
The Washington Post, 1950-53

\section{Autobiographies \& Memoirs}

Acheson, Dean, Present at the Creation: My Years at the State Department, London, 1969

The Korean War, New York, 1971

Bradley, Omar N., and Blair, Clay, A General's Life: An Autobiography by General of the Army Omar N. Bradley, New York, 1983

Kennan, George F., Memoirs 1950-1963, London, 1973

Lilienthal, David E., The Journals of David E. Lilienthal: Vol.2, The Atomic Energy Years, 1945 1950, New York, 1964.

The Journals of David E. Lilienthal: Vol.3, Venturesome Years, 1950-1955, New York, 1966

MacArthur, Douglas, Reminiscences, London, 1965

Nitze, Paul H. with Smith, A. M. and Rearden, S. L., From Hiroshima to Glasnost: At the Centre of Decision, A Memoir, New York, 1989

Panikkar, K. M., In Two Chinas: Memoirs of a Diplomat, London, 1955

Ridgway, Matthew B., The War In Korea, London, 1968

Rusk, Dean, As I Saw It, New York, 1990

Taylor, Maxwell D., Swords and Ploughshares: A Memoir, New York, 1972

Truman, Harry S., Memoirs of Harry S. Truman: Vol.2, 1946-52, Years of Trial and Hope, New York, 1986 


\section{Official Histories}

Condit, Doris M., History of the Office of the Secretary of Defense: The Test of War, 1950-1953,

Washington, DC, 1988

Hermes, Walter G., United States Army in the Korean War: Truce Tent and Fighting Front,

Washington, DC, 1966

Schnabel, James F., United States Army in the Korean War: Policy and Direction, The First Year,

Washington, DC, 1972

Schnabel, James F., Watson, R. J., History of the Joint Chiefs of Staff: The Joint Chiefs of Staff and National Policy, Vol.3, The Korean War, Parts 1 and 2, Wilmington, 1979

\section{Journal Articles}

Anders, Roger M., 'The Atomic Bomb and the Korean War: Gordon Dean and the Issue of Civilian Control', Military Affairs, Vol.52, No.1 (January, 1998), pp.1-6

Calingaert, Daniel, 'Nuclear Weapons and the Korean War', The Journal of Strategic Studies, Vol.11, No. 2 (June, 1988), pp.177-202

Casey, Steven, 'White House Publicity Operations During the Korean War, June 1950-June 1951', Presidential Studies Quarterly, Vol.35, No.4 (December, 2005), pp.69-717.

Crane, Conrad C., 'To Avert Impending Disaster: American Military Plans to Use Atomic Weapons During the Korean War', The Journal of Strategic Studies, Vol.23, No.2 (June, 2000), pp.72-88

Dingman, Roger, 'Atomic Diplomacy During the Korean War', International Security, Vol.13, No.3 (Winter, 1988-1989), pp.50-91

Erskine, Hazel Gaudet, 'The Polls: Atomic Weapons and Nuclear Energy', The Public Opinion Quarterly, Vol.27, No.2 (Summer, 1963), pp.155-190.

Halperin, Morton H, 'The Limiting Process in the Korean War', Political Science Quarterly, Vol.78, No.1 (March, 1963), pp.13-39 
Kennan, George (writing as 'X'), 'The Sources of Soviet Conduct', Foreign Affairs, Vol.25, No.4 (July, 1947), pp.566-582

Mueller, John E., 'Trends in Popular Support for the Wars in Korea and Vietnam', The American Political Science Review, Vol.65, No.2 (June, 1971), pp.358-375.

'Public Expectations of War During the Cold War', American Journal of Political Science, Vol.23, No.2 (May, 1979), pp.301-329.

Oppenheimer, J. Robert, 'Comments on the Military Value of the Atom', The Bulletin of the Atomic Scientists, Vol.7, No.2 (February, 1951), pp.43-45

Rabinowitch, Eugene, 'Atomic Weapons and the Korean War', The Bulletin of the Atomic Scientists, Vol.6, No.7 (July, 1950), p.194\&217

Rosenberg, David Alan, 'U.S. Nuclear Stockpile, 1945-1950', The Bulletin of the Atomic Scientists, Vol.38, No.5 (May, 1982), pp.25-30

Strunk, Mildred, 'The Quarter's Polls', The Public Opinion Quarterly, Vol.15, No.2 (Summer, 1951), pp.381-400.

Trachtenberg, Marc, 'A "Wasting Asset": American Nuclear Strategy and the Shifting Nuclear Balance, 1949-1954', International Security, Vol.13, No.3 (Winter, 1988-1989), pp.5-49

\section{Books}

Anders, Roger M., Forging the Atomic Shield: Excerpts from the Office Diary of Gordon E. Dean, Chapel Hill, 1987

Betts, Richard K., Nuclear Blackmail and Nuclear Balance, Washington, DC, 1987 Soldiers, Statesmen, and Cold War Crises, Cambridge, 1977

Bird, Kai and Sherwin, Martin, American Prometheus: The Triumph and Tragedy of J. Robert Oppenheimer, London, 2008 
Botti, Timothy J., Ace In The Hole: Why The United States Did Not Use Nuclear Weapons In The Cold War, 1945 to 1965, Westport, 1996

Boyer, Paul, By The Bomb's Early Light: American Thought and Culture at the Dawn of the Atomic Age, Chapel Hill, 1994

Brodie, Bernard, Strategy in the Missile Age, Princeton, 1965

Caridi, Ronald J., The Korean War and American Politics: The Republican Party as a Case Study, Philadelphia, 1968.

Carroll, James, House of War: The Pentagon and the Disastrous Rise of American Power, New York, 2006.

Casey, Steven, Selling the Korean War: Propaganda, Politics, and Public Opinion 1950-1953, Oxford, 2008

Caute, David, The Great Fear: The Anti-Communist Purge Under Truman and Eisenhower, New York, 1978

Crane, Conrad C., American Airpower Strategy in Korea, 1950-1953, Lawrence, 2000

Cummings, Bruce, Child of Conflict, Seattle, 1983

Feaver, Peter Douglas, Guarding the Guardians: Civilian Control of Nuclear Weapons in the United States, Ithaca, 1992

Foot, Rosemary, The Wrong War: American Policy and the Dimensions of the Korean Conflict, 19501953, Ithaca, 1985

Gaddis, John Lewis, The Cold War, London, 2005

The Long Peace: Inquiries Into the History of the Cold War, New York, 1987

Strategies of Containment: A Critical Appraisal of Postwar American National Security Policy,

New York, 1982 
The United States and the End of the Cold War: Implications, Reconsiderations, Provocations,

New York, 1992

We Now Know: Rethinking Cold War History, Oxford, 1997

Gaddis, John Lewis, Gordon, P.H., May, E. R. \& Rosenberg, J. (eds), Cold War Statesmen Confront the Bomb: Nuclear Diplomacy Since 1945, Oxford, 1999

Goncharov, Sergei N., Lewis, J.W. and Litai, X., Uncertain Partners: Stalin, Mao, and the Korean War, Stanford, 1993

Halliday, Jon, and Cumings, Bruce, Korea: The Unknown War, London, 1988.

Hayes, Peter, Pacific Powderkeg: American Nuclear Dilemmas in Korea, Lexington, 1991.

Herken, Gregg, The Winning Weapon: The Atomic Bomb in the Cold War 1945-1950, Princeton, 1988

Herzstein, Robert E., Henry R. Luce, Time, and the American Crusade in Asia, New York, 2005

Hewlett, Richard G., and Duncan, F., Atomic Shield, 1947-1952: Volume 2 of a History of the United States Atomic Energy Commission, University Park, 1969

James, D. Clayton, The Years of MacArthur, Vol.3: Triumph and Disaster, 1945-1964, Boston, 1985

Kaufman, Burton I., The Korean War: Challenges in Crisis, Credibility, and Command, Philadelphia, 1986

LaFeber, Walter, The American Age: United States Foreign Policy At Home And Abroad, $2^{\text {nd }}$ edition, New York, 1994

Li, Xiaobing, Millett, Allan R., Yu, Bin (trans. \& eds.), Mao's Generals Remember Korea, Lawrence, 2001 
Lowitt, Richard, The Truman-MacArthur Controversy, Chicago, 1967

Lynn-Jones, Sean M. \& Miller, S. E., The Cold War and After: Prospects for Peace, expanded edition, Cambridge (MA), 1997

Marwick, Arthur, The Nature of History, $3^{\text {rd }}$ edition, London, 1989

Mitchell, George Charles, Matthew B. Ridgway: Soldier, Statesman, Scholar, Citizen, Mechanicsburg, 2002

Mueller, John E., Retreat From Doomsday: The Obsolescence of Major War, New York, 1989

War, Presidents and Public Opinion, New York, 1973

Prados, John, The Soviet Estimate: U.S. Intelligence Analysis and Soviet Strategic Forces, Princeton, 1986

Oshinsky, David M., A Conspiracy So Immense: The World of Joe McCartby, New York, 1983.

Rhodes, Richard, Dark Sun: The Making of the Hydrogen Bomb, New York, 1995.

Spanier, John, The Truman-MacArthur Controversy and the Korean War, Cambridge (MA), 1959.

Stairs, Denis, The Diplomacy of Constraint: Canada, the Korean War, and the United States, Toronto, 1974

Stueck, William, Rethinking the Korean War: A New Diplomatic and Strategic History, Princeton, 2002

Tannenwald, Nina, The Nuclear Taboo: The United States and the Non-Use of Nuclear Weapons Since 1945, Cambridge, 2007

Weintraub, Stanley, MacArthur's War: Korea and the Undoing of an American Hero, New York, 2000

Whiting, Allen S., China Crosses the Yalu: The Decision to Enter the Korean War, Stanford, 1960 
Wittner, Lawrence S., The Struggle Against the Bomb, Vol.1: One World Or None: A bistory of the nuclear disarmament movement through 1953, Stanford, 1993

The Struggle Against the Bomb, Vol.2: Resisting the Bomb: A bistory of the world nuclear disarmament movement, 1954-1970, Stanford, 1997

Zegart, Amy B., Flawed By Design: The Evolution of the CLA, JCS, and NSC, Stanford, 1999 